\title{
CONTU REVISITED: \\ THE CASE AGAINST COPYRIGHT \\ PROTECTION FOR COMPUTER \\ PROGRAMS IN MACHINE- READABLE FORM
}

\author{
Pamela Samuelson*
}

\begin{abstract}
Professor Samuelson casts a critical eye on the Final Report of the National Commission on New Technological Uses of Copyrighted Works (CONTU) which recommended that copyright protection be extended to machine-readable versions of computer programs. CONTU appears to have misunderstood computer technology and misinterpreted copyright tradition in two significant respects. The Commission failed to take into account the historical importance of disclosure of the contents of protected works as a fundamental goal of both the copyright and patent laws. It also erroneously opined that the utilitarian character of a work was no bar to its copyrightability when both the statute and the case law make clear that utilitarian works are not copyrightable. Since computer programs in machine-readable form do not disclose their contents and are inherently utilitarian, copyright protection for them is inappropriate. Congress acted on CONTU's recommendation without understanding the significance of these conceptual faws. Professor Samuelson recommends the creation of a new form of intellectual property law specifically designed for machine-readable programs.
\end{abstract}

I. INTRODUCTION

II. What Computer Programs Are and How They WORK

A. Developments in Hardware Design ............. 673

B. The Different Types of Programs ............... 676

1. Microcode ............................... 676

2. Operating Systems $\ldots \ldots \ldots \ldots \ldots \ldots \ldots \ldots \ldots . \ldots \ldots$

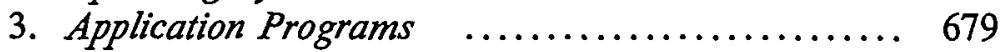

Copyright ( $\odot$ Pamela Samuelson, 1984

* Associate Professor of Law, University of Pittsburgh School of Law. The author wishes to give particular thanks to Lawrence Rudolph of the computer science faculty at CarnegieMellon University for his patient and thorough explanations of computer science concepts and for his substantial editorial assistance. The author also thanks the many other computer scientists who wittingly or unwittingly assisted the author in understanding programs and the concerns computer scientists have about legal protection for programs. 
C. The "Writing" of a Program .................. 682

D. The Ease with Which Programs Can Be Copied .... 689

E. The Threat of Software Piracy $\ldots . . . . . . \ldots . \ldots . . .690$

III. Why Copyright Was Perceived to Be a Solution to the Problem of Legal Protection for Computer Programs: Copyright Office Practice, CONTU, and

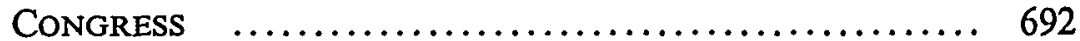

A. Copyright Office Practice $\ldots \ldots \ldots \ldots \ldots \ldots \ldots . \ldots . \ldots 62$

B. The 1976 Revision of the Copyright Law .......... 693

C. CONTU's Mandate from Congress .............. 694

D. CONTU on Copyrightability of Machine-Readable Programs .................................. 699

E. Inadequacies of the CONTU Final Report ........ 703

IV. Doctrinal Difficulties with FitTing Machine-

ReAdable Programs INTO THE COPYRIGHT

FRAMEWORK ................................ 705

A. The Failure of Machine-Readable Programs to Disclose the Ideas They Contain ........................ 705

1. Disclosure as a Goal of Copyright Law ........ 706

2. The Code-Book Cases ....................... 713

3. Copyright Office Policy on Disclosure of Computer Programs ................................ 715

4. Protecting Trade Secrets by Copyright ......... 717

5. Protecting Patentable Ideas by Copyright ....... 719

6. CONTU on Disclosure ..................... 722

7. Hersey's Challenge $. . . \ldots \ldots \ldots \ldots \ldots \ldots \ldots . . . \ldots 25$

8. Disclosure and the Information-Rich Society .... 726

B. The "Utilitarian" Character of Machine-Readable

Programs as a Copyright Problem .............. 727

1. An Historical Perspective on the Utility Rule .... 728

2. Why Copyright Protection Does Not Extend to Utilitarian Works ........................ 732

3. A Corollary Rule Against Copyright for Machines

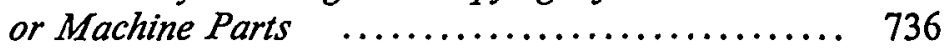

4. The Utility of Computer Chips .............. 739

5. The Utility of Computer Programs ........... 741

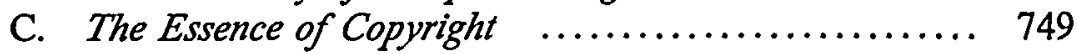

V. How the Computer Industry Perceives Present Theories of Legal Protection for Programs ..... 754

A. Perceived Limitations of Copyright Law .......... 754

B. Perceived Limitations of Patent Protection ......... 756

C. Perceived Limitations of Trade Secret Law ........ 760 


\section{INTRODUCTION}

Nine years ago, the National Commission on New Technological Uses of Copyrighted Works (CONTU) convened to inake recommendations to Congress about whether any revisions of the copyright law were needed to make adequate provision for protection of copyrighted works used in conjunction with computers and other newly developed technological devices. ${ }^{1}$ Among the issues the Commission considered was whether computer prograins in machine-readable form were proper subject inatter for copyright. ${ }^{2}$ The Commission concluded that they were, and recommended that Congress anend the copyright law to provide explicitly that computer programs are within the domam of copyright. ${ }^{3}$

Serious doubts about the wisdom of adopting these recommendations were raised by several commissioners, chiefly Commissioner John Hersey, an eminent man of letters, ${ }^{4}$ and Commissioner Melville Nim-

1. The 93rd Congress authorized establishment of this Commission as a part of the Act of Dec. 31, 1974, Pub. L. No. 93-573, tit. II, 88 Stat. 1873, 1873-74. Congress gave the Commission three ycars to conduct a study and report on computer-related uses and reproductions of copyrighted works and of photocopying practices and technologies. Id. See infra notes 117-27 and accompanying text for inore detail on this 1974 legislation. This article will focus only on the issues raised by that part of CONTU's work that concerned the copyrightability of conputer programs in inachime-readable form.

President Ford announced the appoimtment of the commissioners in mid-July, 1975. The comnnissioners held their first meeting in October, 1975, and issued their final report on July 31 , 1978. See National Commission on New Technological Uses of Copyrighted Works, FINAL REPORT 3-8 (1979) [hereinafter cited as CONTU FINAL REPORT]; infra notes 133-60 and accompanying text.

2. This issue was not one whicl Congress explicitly designated as a subject for CONTU's study. Nevertheless, it was within the broad scope of the statutory inandate. See Act of Dec. 31, 1974, Pub. L. No. 93-573, tit. II, $\S 201$, 88 Stat. 1873, 1873-74. The attention given by the Commission to this topic seenns to have been greater than that given to other computer-relatcd issues that Congress had more explicitly directed CONTU to study. Of the 38 pages in the CONTU Final Report devoted to computcr-related issues, 29 are devoted to the copyrightability of coinputer programs, while three focus on copyright ownership of computer-generated works, and six focus on copyright issues related to data bases. See CONTU FINAL REPORT, supra note 1, at cl. III.

3. See CONTU Final RePORT, supra note 1, at 1-2.

4. See Dissent of Commissioner Hersey, CONTU Final Report, supra note 1, at 27-37 [hereinafter cited as Hersey Dissent]. Commissioner Rhoda Karpatkin also dissented. Her dissenting statement indicates that she shared Commissioner Hersey's doubts about the advisability of treating coinputer programs as copyrightable subject matter, and that Commissioner Dix, who 
mer, the leading scholar of copyright law. ${ }^{5}$ Dissenting Coinmissioner Hersey stated that "forcible wrenching" would be required to fit coinputer programs in machine-readable form withm the copyright framework. Hersey feared that forcing the fit would result in "distortions of traditional copyright usages" that "must im the long run tend to corrupt and erode the essential purposes of copyright."6 Commissioner Ninmer warned that adoption of the Commission's recoininendations might take copyright law "beyond the breaking poimt," converting copyright into a general misappropriation law, which he thought unwise and possibly unconstitutional. ${ }^{7}$ Because of the industry's strong asserted need for protection, he was willing to go along with the Commission's recommendation; yet he recognized that, in the future, Congress might want to adopt a more limited approach to grantimg copyright protection to computer programs, one which would be more compatible with copyright tradition. ${ }^{8}$

The Congress apparently was glad to have the issue resolved by a blue-ribbon commission. It passed without debate in 1980 the amendments to the copyright statute that CONTU had recommended.9 Despite passage of these amendments, several cases raising statutory and

died before the Commission finished its work, shared Hersey's doubts and concerns as well. See Dissent of Commissioner Karpatkin, CONTU FINAL REPORT, supra note 1, at 37-38.

5. Commissioner Nimmer concurred in the majority position, but expressed some substantial doubts about the implications for copyright of extending such protection to computer programs. See Concurring Opinion of Commissioner Nimmer, CONTU FINAL REPORT, supra note 1, at 26-27 [hereinafter cited as Nimmer Concurrence]; infra notes 402-09 and accompanying text.

6. Hersey Dissent, supra note 4, at 31 . Specifically, Commissioner Hersey warned that extending copyright protection to computer programs would not, as the Commission apparently expected, lead to greater disclosure of innovative ideas contained in the programs. Id. at 34. See also infra notes 278-82 and accompanying text. This result was, in Hersey's view, contrary to established copyright policy. He was also very concerned about extending copyright protection to something that was essentially a machine-control device. Id. at 28-30. See infra notes 337-45 and accompanying text.

7. Nimmer Concurrence, supra note 5, at 26. See also infra notes 402-04 and accompanying text.

8. Nimmer Concurrence, supra note 5, at 27. See also infra notes 407-12 and accompanying text.

9. The copyright amendments proposed by CONTU were added to H.R. 6933, 96th Cong., $2 d$ Sess. (1980), An Act to Amend the Patent and Trademark Laws, which became Pub. L. No. $96-$ 517, 94 Stat. 3007 (1980) (codified at 17 U.S.C. $\$ \S 101,117$ (1982)). The copyright amendments can be found in the House bill's section IV, which dealt with miscellaneous items. The amendments were relatively minor, involving only the addition of a definition of "computer program" to $\S 101$, the deletion of the interim $\S 117$, and the substitution of a new $\S 117$ to give owners of copyrighted programs the right to make modifications in them and to make archival copies. See H.R. 6933, 96th Cong., 2d Sess. (1980).

Although there is considerable legislative listory concerning the patent and trademark issues of this law, very little legislative listory focused on the copyright issues. The House Report on the bill mentions that the bill embodies the CONTU recommendations, but does not discuss the copyrightability issues. See H.R. REP. No. 1307, 96th Cong., 2d Sess. pt. 1 at 23 (1980), reprinted 
constitutional questions about whether computer prograins in inachinereadable form are, or can be, copyrightable subject matter have recently been decided. These cases seem to be of two sorts. The cases that have found machine-readable programs protectible by copyright ${ }^{10}$ have treated the defendants' arguments agamst copyrightabihty as if the defendants were simply pirates in search of a loophole, ${ }^{11}$ as they seem to have been im most cases. ${ }^{12}$ The opinions in those cases have tended to be quite brief ${ }^{13}$ and have made little or no effort to place

in 1980 U.S. CODE CONG. \& AD. NEws 6460, 6482. See also Keplinger, Computer Software-Its Nature and Protection, 30 EMORY L.J. 483, 502 (1981).

10. See Apple Computer, Inc. v. Franklin Computer Corp., 714 F.2d 1240 (3d Cir. 1983); Williams Elecs., Inc. v. Artic Int'l, Inc., 685 F.2d 870 (3d Cir. 1982); Apple Computer, Inc. v. Formula Int'h, Inc., 562 F. Supp. 775 (C.D. Cal. 1983), affd, 725 F.2d 521 (9th Cir. 1984); Midway Mfg. Co. v. Strohon, 564 F. Supp. 741 (N.D. Ill. 1983); Hubco Data Prods. Corp. v. Management Assistance, Inc., 2 CopYriGht L. ReP. (CCH) II 25,529 (D. Idaho Feb. 3, 1983); GCA Corp. v. Chance, 217 U.S.P.Q. 718 (N.D. Cal. 1982); Tandy Corp. v. Personal Micro Computers, Inc., 524 F. Supp. 171 (N.D. Cal. 1981).

I1. See, e.g., Tandy Corp. v. Personal Micro Computers, Inc., 524 F. Supp. 171, 175 (N.D. Cal. 1981). In interpreting the meaning of $\S 117$, the temporary provision on computer-related issues in the Copyright Act of 1976, Pub. L. No. 94-553, 90 Stat. 2541, 2565 (codified at 17 U.S.C. $\S \S 101,117$ (1976) (deleted from I7 U.S.C. in 1980); see supra note 9, the court stated that $\$ 117$ "was not intended to provide a loophole by which someone could duplicate a computer program fixed on a silicon chip." See also Williams Elecs., Inc. v. Artic Int'l, Inc., 685 F.2d 870, 877 (3d Cir. 1982), in which the court said, "We cannot accept defendant's suggestion that would afford an unlimited loophole by which infringennent of a computer program is limited to copying of the computer prograin text but not to duphication of a computer prograin fixed on a silicon chip."

12. In GCA Corp. v. Chance, 217 U.S.P.Q. 718 (N.D. Cal. 1982), the defendants were former employees of the plaintiff who seemed to have availed themselves of the opportunity to copy alınost exactly the plaintiffs computer programs. In Hubco Data Prods. v. Managennent Assistance, Inc., 2 COPYRIGHT L. REP. (CCH) ๆ 25,529 (D. Idaho Feb. 3, 1983), the alleged infringer was a licensee of the prograin who broke the encryption code with which the prograin owner had tried to protect its work. In Williams Elecs., Inc. v. Artic Int'l, Inc., 685 F.2d 870, 876 n.6 (3d Cir. 1982), there was, in the court's view, overwhelming evidence that the Willians videogame prograin had been copied; Artic had even copied the coded copyright notice Williams had inserted into its prograin. Artic was no stranger to copyright infringement actions involving videogames. It had been named a defendant in at least one other such action at about the saine tine. See Midway Mfg. Co. v. Artic Int'l, Inc., 547 F. Supp. 999 (N.D. Ill. 1982), affd, 704 F.2d 1009 (7th Cir. 1983) (alleged infrimgement of "PacMan" and "Galaxian" gaines). Three cases, Apple Computer, Inc. v. Franklin Computer Corp., 714 F.2d 1240 (3d Cir. 1983), Apple Coinputer, Inc. v. Formula Int'l, Inc., 562 F. Supp. 775 (C.D. Cal. 1983), affd, 725 F.2d 521 (9th Cir. 1984), and Tandy Corp. v. Personal Micro Computers, Inc., 524 F. Supp. 171 (N.D. Cal. 1982), involved the copying-with little or no variation-of operating systein programs encoded on disks or silicon memory chips. See infra notes 52-56 and accompanying text for an explanation of operating systein programs. In Midway Mfg. Co. v. Strohon, 564 F. Supp. 741 (N.D. Ill. 1983), the defendant was found not to have copied the audiovisual aspect of a videogame, but nonetleless to have illicitly copied the computer program underlying the audiovisual work.

13. The copyright portion of the GCA opinion, GCA Corp. v. Clance, 217 U.S.P.Q. 718, 71819 (N.D. Cal. 1982), is about one and one-half pages long. The whole of the Tandy opinion, Tandy Corp. v. Personal Micro Computers, Inc., 524 F. Supp. 171 (N.D. Cal. 1981), is about four pages long, most of which deals with the proper interpretation of the provisional $\$ 117$ in the Copyright Act of 1976. The Williams Electronics, Williams Elecs., Inc. v. Artic Int'l, Inc., 685 F.2d 
computer programs within the traditions of copyright law. ${ }^{14}$ They have tended to rely for support on the CONTU report, on the 1980 amendments, on the videogame audiovisual copyright cases, and on one another. ${ }^{15}$

The courts that have expressed profound doubts about whether computer programs im machine-readable form can be protected by copyright law have made strenuous efforts to reconcile such protection

870 (3d Cir. 1982), and Strohon, Midway Mfg. Co. v. Strohon, 564 F. Supp. 741 (N.D. Ill. 1983), cases both involved claims of infringement of audiovisual copyrights as well as of computer program copyrights. Although these opinions are nine and thirteen pages, respectively, in length, only three pages of Williams and four and one-half pages of Midway are devoted to the issues concerning the copyright in the computer program. The Third Circuit opinion in Apple Computer, Inc. v. Franklin Computer Corp., 714 F.2d 1240 (3d Cir. 1983), is mostly a reprise of points made in Williams. Hubco Data Prods. v. Management Assistance, Inc., 2 Copyright L. Rep. (CCH) \ 25,529 (D. Idaho Feb. 3, 1983), is a longer than average opinion on this subject, but most of its discussion focuses on the facts of the case and on publication and originality issues, rather than copyrightability of computer programs per se. The district court opinion in Apple Computer, Inc. v. Formula Int'1, Inc., 562 F. Supp. 775, 777-84 (C.D. Cal. 1983), affd, 725 F.2d 521 (9th Cir. 1984), is an exception, devoting seven pages to the copyrightability issue; it acknowledges that computer programs fit poorly into the copyright frainework, but says such arguments should be made to Congress. 562 F. Supp. at 783. The court of appeals decision in Apple Computer, Inc. v. Fornnula Int'1, Inc., 725 F.2d 521 (9th Cir. 1984), devotes only two pages to the copyrightability issue.

14. Contrast the careful development of the compatibility of the copyrightability of videogames as audiovisual works and traditional copyright doctrines in such cases as Midway Mfg. Co. v. Artic Int'1, Inc., 547 F. Supp. 999 (N.D. Ill. 1982), affd, 704 F.2d 1009 (7th Cir. 1983) and Atari, Inc. v. North American Philips Consumer Elecs. Corp., 672 F.2d 607 (7th Cir. 1982), with the analysis of the copyrightability of machine-readable versions of programs in any of the cases cited supra note 10.

15. Tandy Corp. v. Personal Micro Computers, Inc., 524 F. Supp. 171 (N.D. Cal. 1981), was the first of these cases. Although CONTU had by then issued its final report, no mention was made of the CONTU Final Report or of the videogame cases. Tandy was decided before most of the videogame audiovisual cases were decided or reported. Tandy, 524 F. Supp. at 174-75, cites the legislative history of the Copyright Act of 1976 and the Niminer treatise, 2 M. NimMER, NimMER ON COPYRIGHT $\& 8.08$ (1983), and distinguishes two prior opinions which were precedent for the defendant's contentions. Five cases-Apple Computer, Inc. v. Franklin Coinputer Corp., 714 F.2d 1240, 1246-54 (3d Cir. 1983); Williams Elecs., Inc. v. Artic Int'1, Inc., 685 F.2d 870, 875-77 (3d Cir. 1982); Hubco Data Prods. Corp. v. Management Assistance, Inc., 2 CopYRight L. ReP. (CCH) I 25,529 at 18,105-06 (D. Idaho Feb. 3, 1983); Midway Mfg. Co. v. Strohon, 564 F. Supp. 741, 749-52 (N.D. Ill. 1983); and Apple Computer Corp. v. Formula Int'1, Inc., 562 F. Supp. 775, 779-85 (C.D. Cal. 1983), aff d, 725 F.2d 521 (9th Cir. 1984)-mention or discuss the CONTU Report, at least one of the videogame cases, and Tandy or another of the computer program cases, and also distinguish one or both of the cases cited infra note 16. Apart from this, their reference to copyright cases or tradition is scant. GCA Corp. v. Chance, 217 U.S.P.Q. 718 (N.D. Cal. 1982), is the barest of all, citing only Tandy and distinguishing Data Cash Sys., Inc. v. JS\&A Group, Inc., 480 F. Supp. 1063 (N.D. Ill. 1979), affd on other grounds, 628 F.2d 1038 (7th Cir. 1980). The videogame audiovisual cases present significantly different copyright issues because protection is based on the visual and aural cliaracteristics of the programs, not on the machine execution im. structions. See infra note 188. 
with traditional copyright doctrine. ${ }^{16}$ In the one opinion of this type handed down after the 1980 amendments, the court was unconvinced that the statute applied to the particular type of program at issue. ${ }^{17}$ When these reconciliation efforts have been unsuccessful, ${ }^{18}$ at least two courts apparently have been willing to let possible pirates go free in order to preserve essential principles of copyright law. Because one of these cases was affirmed on other grounds and the other was reversed on appeal, they have hittle strength as precedent; yet the issues they raise cannot be dismissed as hightly as the cases disputing their conclusions on copyright seem to indicate.

16. Apple Computer, Inc. v. Franklin Computer Corp., 545 F. Supp. 812 (E.D. Pa. 1982), rev'd, 714 F.2d 1240 (3d Cir. 1983); Data Cash Sys., Inc. v. JS\&A Group, Inc., 480 F. Supp. 1063 (N.D. Ill. 1979), aff' on other grounds, 628 F.2d 1038 (7th Cir. 1980). An interesting thing to note about $J S \& A$ is that neither of the parties to the action briefed or argued the issue of the copyrightability of the machine-readable version of the program; the district court raised the issue sua sponte and decided the case on that ground, denying copyright protection to the program encoded on a chip. See JS\&A, 480 F. Supp. at 1068-69. The Seventh Circuit found it unnecessary to reach this issue and explicitly stated that it expressed no opinion on the subject. $J S \& A, 628$ F.2d at 1041. While some have wondered whether the Seventh Circuit inpliedly rejected the district court's view by deciding that the plaintiff had foregone copyright protection by publishing the encoded version of its program without copyright notice, see, e.g., Williams Elecs., Inc. v. Artic Int'l, Inc., 685 F.2d 870, 877 (3d Cir. 1982), there is no reason not to take the Seventh Circuit at its word. When faced with a choice between a clear basis for a decision and an uncertain basis, either of which is dispositive, courts tend to opt for the former over the latter.

17. Apple Computer, Inc. v. Franklin Computer Corp., 545 F. Supp. 812 (E.D. Pa. 1982), rev'd, 714 F.2d 1240 (3d Cir. 1983), involved an operating system rather than software of the sort to which the CONTU Report refers. See infra notes 52-56 and accompanying text, regarding operating systems, and infra notes 362-99 and accompanying text, regarding the copyright law implications of a distinction based on the difference between operating-system and application programs.

18. In Data Cash Sys., Inc. v. JS\&A Group, Inc., 480 F. Supp. 1063, 1066 n.4 (N.D. Ill. 1979), affd on other grounds, 628 F.2d 1038 (7th Cir. 1980), the court could not reconcile copyright for the program with copyright tradition because the computer program became part of the mechanical functioning of the computer. Moreover, the court was not convinced that the machine-readable version of a program could be a "writing" in the constitutional sense or a "copy" within the statutory definition of that term under the 1909 Copyright Act, lacking, as the encoded program did, communicability with the human user. Id. at 1068-69. These same issues and others-such as the inseparability of idea and expression in a program, the utilitarian character of the particular type of program in machine-readable form that the case involved, and the apparent conflict between copyright and patent law with respect to the type of program the case involved-disturbed the district court in Apple Computer, Inc. v. Franklin Computer Corp., 545 F. Supp. 812, 820-25 (E.D. Pa. 1982), rev'd, 714 F.2d 1240 (3d Cir. 1983). While not holding that operating system programs were not copyrightable subject matter, the Franklin Computer district court declined to issue the preliminary injunction requested by the plaintiff on the ground that reasonable probability of success on the merits had not been established. Id. at 825 .

That a pirate may go free is one of the costs of enforcing the copyright law within its traditional and constitutional bounds. As the Seventh Circuit said in $J S \& A, 628$ F.2d at 1044, with respect to a question of statutory interpretation, "[w]e cannot award the defendants any accolades for their ethics, but this is not the statutory standard." 
The cases-both those which favor and those which disfavor copyright as a form of protection for computer programs-raise a number of serious questions. They raise questions of the constitutionality of extending copyright protection to machine-readable forms of programs. ${ }^{19}$ They raise statutory questions concerning whether certain kinds of programs were intended to be covered by the law. ${ }^{20}$ And they raise serious questions about whether CONTU was correct in concluding that copyright is an appropriate form of protection for coinputer programs in machine-readable form. ${ }^{21}$ Congress, when it implemented the CONTU recommendation, did not understand the extent to which fundamental principles of copyright would be undermined by this action.

Doubts about the appropriateness of copyright as a form of legal protection for computer programs have also surfaced in other areas. ${ }^{22}$ Professor Ralph Brown, a respected copyright scholar, has recently said: "Nothing has challenged the patent and copyright laws like this issue. . . . It raises the question of whether we need a whole new system just to deal with computer chips." ${ }^{23}$ Congress seems already to have begun to reassess copyright as a forn of legal protection for programs. ${ }^{24}$ And the software industry has expressed significant doubts

19. See infra notes $170-399$ and accompanying text.

20. See infra notes $354-99$ and accoinpanying text.

21. See infra notes $170-462$ and accompanying text.

22. The New York Times reported, "[t]he nation's copyright and patent laws, which have protected literary works and inventions for nearly 200 years, apparently fail to safeguard much of the computer technology that many people hope will help revive America's economy, according to a growing number of legislators, judges, and computer executives." N.Y. Times, July 5, 1983, at 1 , col. 6. The article focused on computer programs and semiconductor chip designs. Another $\mathrm{New}$ York Times article noted a more general problem:

Seven years ago, when Congress finished the first complete overhaul of Federal copy-

right law simce 1909, members turned froin the 15-year-long project with relief. Copyright law, they felt, was finally up to date, able to accommodate such 20th century innovations as the photocopy machine.

But the pace of technological cliange lias been so fast since then, a congressional subcounmittee was told this week, that it threatens to render obsolete not only the Copyright Revision Act of 1976 but also the essential premise of copyright itself.

N.Y. Times, July 24,1983 , at 14 , col. 1 .

23. N.Y. Times, July 5, 1983, at 29, col. 1. Ralph S. Brown is Professor Emeritus of Law at Yale University. For a description of a computer "chip", see infra note 32 and accompanying text.

24. In April, 1984, at the request of several congressmen, the Office of Technology Assessment of the U.S. Congress undertook a study of whether current intellectual property law is adequate to the needs of "high tecli" industries, including software production and distribution. Its report is scheduled to be issued in September, 1985. See Congress of the United States, Office of Technology assessment, Project Proposal on Intellectual Property Rights IN AN AGE OF ELECTRONICS \& INFORMATION (March 13,1984) (copy on file with the author) [hereinafter cited as OTA Project Proposal]; see also N.Y. Times, July 24, 1983, at 14, col. 1; Staff of the House Comm. on Science \& Technology, 97th Cong., 1st Sess., IssuesPresent \& Future, Report 70 (Comm. Print 1981). 
about the usefulness of copyright protection for programs. ${ }^{25}$

Computer programs may well deserve to be protected. ${ }^{26}$ The choice, however, is whether to let the courts evolve new rules of copyright doctrine and discard the old rules, whether to amend further the copyright law to avoid the conflicts with copyright doctrine that have already been identified, or whether to devise a new intellectual property law specifically for machine-readable computer programs.

The latter option is not as unthinkable as it may seem at first glance. After all, copyright as a form of legal protection for writings was created to deal with the consequences of the invention of the printing press, which made it possible, for the first time, to make multiple copies of a writing im a relatively short period of time. ${ }^{27}$ Similarly, patent law was responsive to the technological necessities of the Industrial Revolution. ${ }^{28}$ Given that the computer and its programs may have propelled us into a Post-Industrial or Information Revolution, ${ }^{29}$ it is time to think about what kind of intellectual property computer programs are, and to design a form of legal protection appropriate to their characteristics.

Section II of this article describes what computer programs are, not merely in terms of how they are created, but also, and more significantly, in terins of how they function in a computer. That prograns are mere substitutes for computer hardware has not yet been grasped in the copyright hiterature.

Section III reviews Copyright Office policy with respect to coinputer programs prior to the Copyright Act of 1976, the decision to establish CONTU by Congress, the CONTU dehberations and report, and the action taken by Congress in response to the CONTU recom-

25. The prospectus of one computer software company contained this ominous warning: " 'Computer software systems cannot be patented, and any copyright laws nay not be meaningful." ' Seneker \& Pearl, Software to Go, Forbes MAG., June 20, 1983, at 93, 99. See also infra notes $417-49$ and accompanying text.

26. CONTU Commissioners were persuaded that computer programs needed to be given some sort of legal protection im order to stimulate the production and dissemination of software products. See CONTU Final REPoRT, supra note 1, at 10-12. See also infra notes 134, 143, 264 and accompanying text. But see Breyer, The Uneasy Case for Copyright: A Study of Copyright in Books, Photocopies, and Computer Programs, 84 HARv. L. Rev. 281, 340-50 (1970) (questioning the need for copyright protection for programs).

27. See, e.g., A. Latman \& R. Gorman, Copyright for the Eighties: Cases and MATERIAIS 1-4 (1981) (describing the Statute of Anne, enacted in 1710).

28. See, e.g., Subcomm. on Patent, Trademark \& Copyright, Senate Comm. on the Judiciary, 85TH CoNG., 2D SEss., Study No. 15, AN EConomic Review of the PATENT SysTEM 2 (Comm. Print. 1958); Outline of the History of the United States Patent Office, 18 J. PAT. OFF. Soc'Y, July, 1936 at 19-34.

29. See generally D. Bell, The Coming of Post-Industrial Society (1973); D. Hanson, The New Alchemists (1982). 
mendations. The CONTU Final Report is criticized for its failure to consider several important matters and for its inisunderstanding of copyright tradition.

Section IV concentrates its analysis on two of the inyriad difficulties that the atteinpt to integrate inachine-readable programs into the copyright tradition has brought to the surface. The first is the undermining of the constitutional goal of proinoting the progress of science and the arts, a goal that requires disclosure of published works to which copyright attaches. This problem arises because software manufacturers generally market only machine-readable forms of programs, thereby withholding not only their ideas, but inuch or all of the manner in which those ideas are expressed. The second is the undermining of the copyright rule against allowing copyright protection for utihtarian works, a rule which Congress reaffirmed and strengthened in 1976. Disclosure of a published work and nonutility of the work are essential elements of copyright tradition that should be retained.

Section $V$ argues that copyright is not generally perceived by those in the industry as being an efficacious form of legal protection for computer prograins. It also considers the deficiencies of patent and tradesecret law.

Section VI considers the possible solutions: allowing copyright to becolne a general misappropriation law; making soine modifications in the copyright law to retain disclosure and nonutility as general rules of copyright to which machine-readable programs would be a limited exception; or devising a new form of legal protection for machine-readable prograins. It contains suggestions about the characteristics a new legal form of protection should have. It is possible to develop a proposal that will meet the industry's pressing need for effective legal protection without undue sacrifice of the public's interest im obtaiming disclosure of the ideas contained in encoded computer programs.

\section{What Computer Programs Are and How They Work}

Many discussions of the copyrightability of machine-readable forms of programs, particularly those which favor copyright protection, emphasize the set of preparatory writings that may go into producing an operable coinputer program. ${ }^{30}$ Although what they say is correct as far as it goes, it reveals only one aspect of what a program is. A more

30. See, e.g., Apple Computer, Inc. v. Formula Int'l, Inc., 562 F. Supp. 775, 778 (C.D. Cal. 1983); CONTU FINAL REPORT, supra note 1, at 9-10; Iskrant, The Impact of the Multiple Forms of Computer Programs on Their Adequate Protection by Copyright, 18 CopYrIGHT L. SYMP. (ASCAP) 92, $105-06(1970)$. 
complete examination is required to assess the copyrightability of computer software.

This section begins with a description of programs in the context of what coinputers do and how prograins affect them. Because part of the debate on the appropriateness of copyright as a form of protection depends on the answer to the question, "Is it a writing or is it a machine part?," it is essential to understand prograins in their entirety. As one judge faced with this characterization dilemina has aptly said, "[e]qually good analogies lead to contradictory results."31

\section{A. Developments in Hardware Design.}

It is important to note at the outset that the first generation of coinputers $^{32}$ did not utilize what are now referred to as computer programs

31. Apple Computer, Inc. v. Franklin Computer Corp., 545 F. Supp. 812, 823 (E.D. Pa. 1982), rev'd, 714 F.2d 1240 (3d Cir. I983).

32. It is commonly said that to date there have been four "generations" of computers. See E. Feigenbaum \& B. McCordruck, The FifTh Generation 17 (1983) [heremafter cited as Feigenbaum]. See generally B. ARden, What CAN Be Automated?, 10-13, 299-300 (1980).

The "generations" of computers have been distinguished from one another chiefly by the nature of the device used in them to control and amplify electrical currents. All four generations of computers have employed the same general design, which consists of a central processing unit, a memory, an arithmetic unit, and input-output devices. FeIGENBAuM, supra, at 17. All operate in serial fashion, that is, by having the mechanism perform its function one step at a time in a prescribed order. Id. The first generation of computers used electronic vacuum tubes, and hence is referred to as the generation of "electronic vacuum tube computers." FeIGENBAuM, supra, at 17. The ENIAC computer, built in 1946 at the University of Pennsylvania, and often hailed as the first operating electronic digital computer, was of this type. See Boraiko, The Chip, 162 NAT'L GeographIC 421, 429 (1982). The invention of the transistor in 1947 led to the development of the second generation of computers known as "transistorized conputers." See FeIGENBAuM, supra, at 17. This generation of computers was less bulky, more energy efficient, and more rehiable than those that used vacuum tubes, but transistors often becaine disconnected from the circuit boards to which they were supposed to be attacled. To solve this problem, as well as to make transistors smaller, two scientists hit upon the idea of making the crystal in the transistor serve as its own circuit board. See Boraiko, supra, at 429 . The device they invented is known as an "integrated circuit" or "chip." Chips are thim shices of seimiconductor material (usually silicon) in which layers of electronic switches connected by thin wires have been laid. Each switch is functionally a trausistor. Each chip contains several thousand switclies. Id. Chips were a considerable improvement over the transistors they replaced because they were less bulky, cheaper to make, more energy efficient, and more reliable than transistors had been. Not surprisingly, this generation of computers is known as "integrated circuit computers." See FeIgenbaum, supra, at 17. The fourth generation of computers are known as very large-scale integrated (VLSI) coinputers. They too employ integrated circuits, but ones that are more densely packed than the third generation. Clips contaiming 100,000 or more transistors are VLSI chips. See Boraiko, supra, at 429.

Chips have two different functions in current models of computers. Some are nemory units which store information, that is, data or program instructions; others are processing elements of the machine, i.e., the central processing units that are responsible for execution of the program's imstructions. See Boraiko, supra, at 421 . There are two basic types of memory chips: those which have programs or data permanently "burned" imto thein (known as "read only ineniory" or ROM chips because the computer can only "read" the stored information; it can't change or "write" new 
to carry out their computational tasks. Rather, they were constructedor "hard-wired"-in such a way that the machine could perform only the particular function for which it had been wired. To change the operation the machine could accomplish, that is, to enable the machine to perform a different task, the computer's engineers had to rewire or reconfigure the machine. ${ }^{33}$ In other words, the first operating coinputers were all hardware.

An important development in the history of computers was that a computer could be made to store and use encoded imstructions, "programs," to perform particular tasks, thus ehininating the necessity for making modifications to the hardware of the machime to change the tasks that it could perform. ${ }^{34}$ The programmability of computers had a number of important imphications, the most important of which was that computers could now become "universal machines," that is, machines capable of performing any task for which it was possible to create program instructions. ${ }^{35}$ Today virtually all computers are universal

information into this memory device) and those which are capable of receiving data and alterations of that of data (known as "random access memory" or RAM chips). Programs are often distributed in ROM form. RAM chips are used to store data that is to be updated or only temporarily stored in a particular part of the computer's memory. See Toong \& Gupta, Personal Computers, ScI. AM., Dec. 1982, at 87, 87-94. Chips capable of storing more than 260,000 bits (short for "binary digits") of data are currently im production in the U. S. See Bylinsky, The Next Battle in Memory Chips, Fortune MAG., May 16, 1983, at 152.

33. "To perform different operations, [ENIAC] had to be manually rewired, like an old wireand-plug telephone switch board, a task that could take several days." Golden, Big Dimwits and Little Genuises, TIME MAG., Jan. 3, 1983, at 31. One could say that, in a sense, such a inachine was programmed by its hardware. That is, the order in which the machine would execute its primitive functions was set by the inanner in which the hardware had been constructed. But this is using the word "program" in a very different sense from the way one uses it today to refer to the set of written instructions which are translated to binary code, stored in a computer, and used to cause a computer to perform a useful function.

34. "The principle of the stored program, the invention of which was a milestone in the development of the modern digital coinputer, makes it possible to change the function of a coinputer by changing the contents of its inemory urit instead of by changing its hardware." Patterson, Microprogramming, ScI. AM., March 1983, at 50, 52. The Hungarian mathematician Jolin von Neumann first "suggested putting the machine's operating instructions, or program, within the same memory as the data to be processed and writing it in the same binary language. The computer could thus be programmed through the same imput devices used to feed in data, such as a keyboard or a reel of tape." Golden, supra note 33, at 31. The first commercial programmable computer was the Sperry-Rand UNIVAC, first manufactured in 1951. Id.

35. See, e.g., A. Hodges, Alan Turing: The Enigma 293-95, 318-21 (1983). Hodges quotes the mathematician and early computer scientist Alan Turing: "We do not need to have an infinity of different machines doing different jobs. A single one will suffice. The engineering problem of producing various machines for various jobs is replaced by the office work of 'programming' the universal inachine to do these jobs." Id. at 293. See also D. HANson, supra note 29, at 39-68. 
machines. ${ }^{36}$ The differences among present-day computers-from the supercomputer to the microprocessor on a chip-are not so much the tasks they can accomplish, but the speed and efficiency with which they can accomplish them, their memory capacities, and their cost. ${ }^{37}$

While the programmable computer has a number of advantages over the completely hardwired computer, programmability did not make it possible for computers to perform tasks that a hardwired computer could not perform, or to perform those tasks faster or better than hardwired computers could. It is possible to construct a customized piece of hardware to do any given task that might otherwise be programmed on a universal machine. ${ }^{38}$ A completely hardwired machine may do that given task more rapidly than a programmed computer. ${ }^{39}$ The prime advantage of the programmable computer is its generality. That is, it does away with the need to construct many different kinds of machines because one machine can be built and prograntmed to perform a variety of functions. Another of the imphications of the development of programmmable computers is that such computers were built so that the hardware itself could no longer perform any useful function without the directions given to it by a computer program. ${ }^{40}$

36. While many modern computers are programmed to perform only one function-running the watch you wear on your wrist, for instance-they may be capable of being programmed to do any number of different things. See, e.g., Boraiko, supra note 32, at 421-25; see also infra note 63.

37. The 1946 ENIAC computer could perform about 5,000 additions per second. Golden, Other Maestro of the Micro, TIME MAG., Jan. 3, 1983, at 29. The supercomputers currently in use can perform several hundred million operations per second. The Race to Build a Supercomputer, NEWSWEEK, July 4, 1983, at 58 . Japanese researchers are aiming to produce supercomputers which will process 10 billion operations per second. Id. at 63 . Personal computers such as the Apple IIe can execute a mere 500,000 operations per second. Id. See also With Stakes High, Race Is On For Fastest Computer of All, N.Y. Times, Feb. 1, 1983, at Cl, col. 2.

One current supercomputer model contains a dense pack of 240,000 silicon chips and costs about $\$ 11$ million. The Race 10 Build a Supercomputer, NewsweEk, July 4, 1983, at 63. Personal computers have far fewer, thirty-one, for example, are used in the Apple IIe. Id. The Apple II Plus model sells for about \$1300. Faflick, The Hottest Selling Hardware, Time Mag., Jan. 1, 1983, at 37. See supra note 32 concerning the inemory capacity of chips.

38. Given a precise definition of a computer, it is always possible to realize the computer in hardware - that is, to construct a hardware device whose machine language is precisely that of the defined computer .... . In suggesting this possibility we are appealing to the important basic principle behind computer design: Any precisely defined algorithm or data siructure may be realized in hardware. Because a computer is simply a collection of algorithms and data structures, we may assume that its hardware realization is a possibility regardless of the complexity of the computer or its associated inachine language.

T. Pratt, Programming languages: Design \& Implementation 19 (2d ed. 1983).

39. This makes sense because many of the features included in the programmable machine are there to give the machine flexibility. The programmable machine will be slowed down by having to carry through operations the hard-wired machine can ehininate or streamline.

40. "The hardware can do nothing by itself; it requires the array of prograins, or instructions, collectively called software." Toong \& Gupta, supra note 32 , at 88 . 
At this point it may be helpful to explain briefly what it means to say a computer is "programmable." The hardware of all programmable computers is capable of performing a set of primitive functions, which may include adding two numbers together, subtracting two numbers, comparing two numbers, and determining if they are the same or different, retrieving something from memory, or routing data to memory for storage. ${ }^{41}$ A program specifies the exact sequence in which the hardware is to execute these primitive functions..$^{42}$

One of the primitive functions of the hardware of a programmable machine that the coinpletely hardwired inachines did not have is the capability of "reading" the next instruction in the program for the next addition, subtraction or other primitive function. ${ }^{43}$ The hardware "reads" 44 a program's instructions by sensing a sequence of electrical impulses that have been encoded to "mean" that the next primitive function to be performed is, for example, addition. Uninstructed, the hardware is inert. Properly programmed, the hardware can perform the series of steps necessary to accomplish a task as directed by the program.

One could say that the set of instructions which constitutes a computer program gives the machine the "knowledge" it needs to do the task, but this is using the word "knowledge" in a very different sense from that in which it is normally used. A more accurate way to describe a prograin would be to say that the program's instructions simply prescribe an order for the hardware's execution of its primitive functions. This is, at base, the definition of a prograin.

\section{B. The Different Types of Programs.}

For the purposes of copyright analysis, it is helpful to view computer programs as falling into three inain categories: (1) microcode, also known as "firmware"; (2) operating systems, sometimes known as "systems software"; and (3) apphication programs, which are what people generally mean when they refer to "software."

1. Microcode. Microcode was developed to respond to one of the same basic problems that attended the completely hardwired com-

41. See T. Pratt, supra note 38 , at $15-16$ for a list of hardware primitive functions.

42. See R. Conway \& D. Gries, an Introduction to Programming 4 (3d ed. 1979).

43. See B. ARDEN, supra note 32, at 12.

44. See, e.g., C. Sippl, Data Communications Dictionary (1976) (defining "read": "To copy, usually from one form of storage to another, particularly from external or secondary storage; to sense the meaning of arrangements of hardware; to sense the presence of information on a recording medium."). See also infra note 163, explaining further the technical meaning of the term "read" when used in relation to computers. 
puter. Given a programmable computer, consisting only of hardware and software, if one wanted to change either the number or the nature of its primitive functions, one still had to disassemble the hardware and reconstruct it.

Microcode is a set of encoded instructions-im other words, a program-that controls the fine details of the execution of one or more primitive functions of a computer. Microcode serves as a substitute for certam elements of the hardware circuitry that had previously controlled that function. ${ }^{45}$ Microcode is generally designed at the same time as and in conjunction with the design of the hardware. ${ }^{46} \mathrm{Al}-$ though, strictly speaking, it is a program, it is considered a more integral part of the machine hardware than is software, hence its alternative name, "firmware." 47

The development of microcode was important for several reasons. ${ }^{48}$ Microcode replaced hardware and thereby reduced the building expense and the bulk of the hardware. It also permitted either the origmal manufacturer of the machine or a subsequent purchaser of the machine to make a change in one of the primitive functions of the computer without tearing the machine apart. Sigmificantly, it also allowed the machine designers to increase the number of functions the hardware could perform, and even to add previously unattaimable functions. ${ }^{49}$ This ability to extend the number of primitive functions of the hardware has become the most miportant characteristic of microcode. Microcode also permits greater fiexibility as to certain primitive func-

45. The function of microcode is discussed at length in a recent Scientific American article: A fundamental issue in the design of any computer is how to control, or steer, the electrical signals that represent information. In the arithmetic and logic unit, where the actual processing of information is done, signals must be routed between various counters, adders, and other coinponents. The control system must also mediate the transfer of information between the central processor, the main memory units, and the various input and output devices. In one approach the control system is completely "hard-wired," that is, it is laid down permanently in the processor's electrical circuitry. A second approach [microcode] is more flexible and im many cases less expensive. The essential idea is to reduce the coinplexity of the control system by recording the detailed instructions for controlling the computer in a coded form. In other words, the sequence of paths a signal is to follow is embodied in a program, which is stored in a separate memory unit incorporated into the processor.

Patterson, supra note 34 , at 50 ; see also id. at 54 regarding the flexibility provided by microcode. 46. See T. Kidder, The Soul of THE NEw MACHINe 97-102 (1982).

47. " $[\mathrm{M}]$ icro programs are sometimes classified as firmware, thereby signifying their intermediate status between hardware and software." Patterson, supra note 34, at 50.

48. See $i d$. at 56 regarding the advantages of microcode.

49. Some hardware, for example, does not mclude multiplication as one of its primitive functions, except, of course, by sequential additions. Microcode can add multiplication to the set of primitive functions such hardware can perform. 
tions than does hardware alone. ${ }^{50}$ Finally, microcode allowed certain very common sequences of primitive functions to be encoded so that subsequent programmers are relieved from the task of writmg a set of instructions to carry out those sequences of functions cach time they write a program to be executed on that computer..$^{51}$

2. Operating Systems. Although conceptually inicrocode and operating systems are distinct, they liave many common features. For one thing, both are computer programs. For another, both are designed to control imternal functions of the computer. Third, both are invisible to one who is using the computer to perform a particular task. Fourth, neither in itself is capable of making the machine perform a useful function; it is the application prograns that enable the computer to perform their external functions. Fifth, both are designed to facilitate the user's ability to program the machine to perform application tasks.

Operating systems, however, are considered to be a category of software. ${ }^{52}$ While it is possible for some operating system functions to be microcoded, generally speaking, the two are distinct. ${ }^{53}$ Microcode attends to the primitive functions of the inachine. An operating system attends to interrelation between the hardware and the application program the hardware may be about to execute. ${ }^{54}$

Computers sold today generally come equipped with an operating system that was designed by-or at least for-the manufacturer. The Apple II, for imstance, was sold witl a set of fourteen operating system

50. There are, for instance, different ways to round off numbers when one multiplies sets of them. One way may be useful for one application, but not for another. Microcode allows the round-off function to be coded im more than one way so that a user of the machine can decide which way suits his or lier purposes for particular applications.

51. See Patterson, supra note 34 , at 54-55.

52. "The part of the software that is inost closely associated with the hardware is the operat" ing system." Toong \& Gupta, supra note 32, at 96.

53. At one point in its opinion, the district court in Apple Computer, Inc. v. Franklin Coinputer Corp., 545 F. Supp. 812, 824 (E.D. Pa. 1982), rev'd, 714 F.2d 1240 (3d Cir. 1983), may have mistaken the operating system programs involved in that case for firmware. But it is true that the operating system programs in that case could have been unicrocoded, or even unade part of the hardware, as supra note 38 and accompanying text have explamed, so that the basic point the district court was trying to make about the potential probleun of copyright/patent conflict because of the patentability of firmware was well taken. See infra notes 332-33 and accoinpanying text regarding the patent/copyright conflict.

54. "The core of the software is an 'operating systein' that controls the computer's operations and manages the flow of information. The operating systein mediates between the inachine and the human operator and between the machine and an 'apphication' prograin that cnables the computer to perform a specific task." Toong \& Gupta, supra note 32, at 88. Note that the hardware the operating system imterfaces with includes the microcode. See infra note 61 and accompanying text concerning the concept of the virtual machine. 
programs. ${ }^{55}$ An operating system is analogous to secretarial assistance to an executive. When an executive wants to get some figures out of the files, he or she does not normally start rummaging through the office filing system. Rather, the executive will call upon a secretary to do the file search. The secretary will know how to gain access to the files, where the files are located, and how they are organized. The secretary can use that knowledge to retrieve the desired information froin the files. The operating system of a computer performs similar tasks. It contains a series of routines which virtually all application prograins require. ${ }^{56}$ The operating systein obviates the necessity for each programmer using the system-or writing a program for use in a particular computer-to write out the sequence of instructions to perform thesc routines. When the computer reaches the instruction in the application prograin which, for exainple, directs the retrieval of a file from a disk and the transfer of it to main menory, the operating system will take over, instructing the inachine to perform that function.

3. Application Programs. Application prograins are the software programs with which the public has come to be familiar. Software connotcs to the public the word processors we use for our writing, the videogames we play, the spread sheets we use to make our business calculations, and the payroll systems that print out our paychecks. ${ }^{57}$ But the reahty of what application prograins are in connection with what computers do is a bit nore complicated than the popular view suggests.

The term "application prograin" has a inore dynainic and functional meaning than one might suppose. The same program that in a

55. See Apple Computer, Inc. v. Franklin Computer Corp., 545 F. Supp. 8I2, 815-16 (E.D. Pa. 1982), rev'd, 714 F.2d 1240 (3d Cir. 1983). See also B. ARDEN, supra note 32, at 563 (hardware manufacturer now routinely supplies the operating system).

56. To understand the kinds of tasks done by the operating system, consider the sequence of steps that must be taken to transfer a file of data from the primary memory to disk storage. It is first necessary to make certain there is enough space available on the disk to lold the entire file. Other files might have to be deleted in order to assemble enough contiguous blank sectors. For the transfer itself sequential portions of the file must be called up from the primary memory and combined with "lousekeeping" information to form a block of data that will exactly fill a sector. Each block must be assigned a sector address and trausmitted to the disk. Numbers called check-sums that allow errors in storage or transmission to be detected and sometimes corrected must be calculated. Finally, some record must be kept of where the file of mformation has been stored.

If all these tasks had to be done under the direct supervision of the user, the storage of information in a computer would not be wortl the trouble. Actually the entire procedure can be handled by the operating system; the user merely issues a single command, such as "save file."

Toong \& Gupta, supra note 32, at 96.

57. See Boraiko, supra note 32, at 421-25; Friedrich, The Computer Moves In, TIME MAG., Jan. 3, 1983, at 14-23. 
digital watch may be an "apphication program" may serve as a timing device in an operating system program, and in that context it is not an "application program." What an application program is, from a computer scientist's standpoimt, depends on what the user wants to do with a computer at any given time..$^{58}$ One has a computer; one has an application, that is, a task, that one wants that computer to perform; the program that will bring about the desired result is the "application program" for that task. 59

To be precise, we must reakize that it is not the application program alone that perforins the task we ask the computer to do. Nor is it the hardware alone. Rather, it is the complex hierarchy of programs and hardware that, while interacting with one another, works as a unit to perfornn a particular application task. ${ }^{60}$ Computer scientists refer to this complex hierarchy as the "virtual machine" or "virtual computer."61 The virtual machine is the computational unit a user confronts when he or she sits down to use it. For functional purposes, the programs in a computer are part of the machine; programs are only substitutes for hardware. They are not hardware per se, but are components of the virtual machine.

Computer programs make it possible for one machine to perform the functions of many machines. When a word processing program is operating in a computer, the computer is a word processor. When a videogame program is operating in a computer, the computer is a videogame machine. When a digital watch program is operating in a computer, the computer is a digital watch. With each new program, the computer is a new machine. We have been so conditioned to regard machines as separate entities fixed by the nature of their hardware to perforn only one function that it is difficult to adjust to this new chameleon-like machine. What a computer program does is to transform

58. See B. ARDEN, supra note 32 , at 13-15.

59. Even microcode can, under this functional definition, be a kind of application program. If the task one prograins the hardware to perform is adding multiplication to the prinnitive functions, the prograin that will do that task is an application program, even if it is also microcode.

60. The preceding discussion might suggest the hierarchy is coinposed solely of hardware, microcode, an operating system, and an application prograin. But any one application task may require calling on more than one operating system program and more than one application prograin. That is, for a particular application, soinething which in another context would be "the" application program may be called on to aid in the accomphishment of another application task. For exanple, a word processing program may call upon a dictionary prograin to check the spelling in a draft of an article in the processor, or upon a footnote conformity program to check that the footnotes to a draft article are in the proper form.

61. "The coinputer that executes the translated prograins may occasionally be a hardware component, but ordinarily it is a virtual computer coinposed partially of hardware and partially of software." T. PRATT, supra note 38, at 14. 
the machine: without changing the hardware, the machine's form and function can be altered by different programs. That is what it means to say the modern coinputer is a universal machine. ${ }^{62}$ The program determines what kind of machine the computer will be.

Computers and their programs have become a highly visible part of our lives. Programs are so visible in our lives partly because they sometimes cause the computer to display things-words, symbols, pictures-on a screen. ${ }^{63}$ Some prograins produce much display. Videogaines, for instance, produce series of highly colorful graphic images and absorbing sounds. Videogames are programmed to be, if you will, "display-intensive." It is the audiovisual display of videogames that makes thein seem so much like other categories of copyrightable works. ${ }^{64}$ Many software programs, however, produce considerably less display. ${ }^{65}$ Some produce no display at all. There is a wide variety of other kinds of output that application programs can generate. ${ }^{66}$

What a program displays is not at all the same thing as the instructions which cause the display to occur. That is, it is not the program mstructions that are displayed on the screen when a program is being executed. In general, one cannot get the program imstructions to be displayed on the screen even if one wants to. ${ }^{67}$ Of course, for the most

62. See supra notes $34-36$ and accompanying text. Not every computer is a universal machine. Some computers are specially designed to serve only a single purpose-for instance, to be digital watches or carburetor injection devices-and have only one program which contains all the instructions the computers will need to perform their specified tasks. These computers resemble somewhat the completely hardwired machines discussed supra at note 33 and accompanying text in that the hardware may be tailored for performance of a specific task.

63. Display is one of the primitive functions now included in the hardware of most computers. The prograin, of course, does not itself directly produce the display. It causes the hardware to produce the display. It is the interaction of the hardware, microcode, operating systems, and software-that is, the virtual computer, see supra note 61 -which produces the display. Each change in the display is orchestrated by the program.

64. Videogames were initially classified as audiovisual works by the Copyright Office. See Midway Mfg. Co. v. Artic Int'l, Inc., 547 F. Supp. 999, 1003 (N.D. Ill. 1982), aff'd, 704 F.2d 1009 (7th Cir. 1983). That explains why most of the early videogane cases discuss the audiovisual nature of these works. See, e.g., Stern Elecs., Inc. v. Kaufman, 669 F.2d 852, 857 (2d Cir. 1982).

65. A dictionary program that checks the spelling of words in a text on a word processing system may be a very large, comphicated program. It will do a great deal of its work in a manner invisible to the user. Such a program will only display misspelled words and a request for corrections by the user.

66. The microcode and operating system programs, discussed supra notes $45-56$ and accounpanying text, produce no visual or auditory displays. Examples of apphication programs that produce no display are a program coutaining instructions for injecting fuel into the carburetor of an automobile and a program for the operation of a heart pacemaker. See Boraiko, supra note 32, at 425.

67. When a program is under development, a programmer will have the source code stored in one file and the machine-readable code in another file on a inemory disk. The prograinmer will be able to have the source code instructions displayed on the screen. But once the program is 
part, the computer user does not want to know what the prograin instructions "say" to the computer. The user does not care how the program does what it does, just that it does what it is supposed to do. Computers are useful to society precisely because they greatly reduce or eliminate the need for the user to go through the tedious ordeal of following the thousand or inore steps of some computational task. Also, the machine, if properly programmed and operating smoothly, does not make the mistakes so often inade by humans.

It is easy to get confused about whether coinputer programs can or should be copyrightable subject matter because a computer can be programmed to be a book. A computer can store, rephicate, display on a screen, and print out Gone With The Wind, a telephone directory, and other types of written inaterials. It can be a book or a book substitute. 68

\section{The "Writing" of a Program.}

It is important to understand precisely what is ineant by the term "computer program."69 The word is often loosely used to refer to a wide range of things: the formulation of an algorithin for solving a particular computational task, one or inore of the preparatory writings created to aid in implementing the algorithin, or the final machme-

operating correctly, the source code becomes superfluous. Only the machine-readable version is generally distributed. See infra note 75 . From the inachine-readable form, one generally cannot have the program instructions displayed on the scrcen because the instructions have been converted to machine language.

68. There are also prograins with large data bases that can serve as book substitutes and have additional capabilities books do not have. Mead Data Central's Lexis and West Publishing Company's WESTLAW service, for example, have put in digital but displayable form all cases decided by courts of various jurisdictions during a defined time period. These cases may also be found in bound volumes published by West. The main advantage of the computerized form of this material is that the computer will not only display it for the user, but will make searches through its data base to locate things which might take a human searcher an inordinate amount of time to find.

Another well-publicized new type of application progran is known as an "expert system." See Feigenbaum, supra note 32, at 63-64; Boraiko, supra note 32, at 445-46. An expert system is a computer program that aims to incorporate sufficient knowledge about a particular field or subfield to allow it to analyze fact situations at an expert's level. It may incorporate not only textbook knowledge on a subject, but also some of the experience-based "hunches" which experts in a fleld would be hikely to apply when faced with certain circumstances. Feigenbaum, supra note 32, at 76-77. Expert systems are now available to aid in the diagnosis of illnesses, id. at 65 , and oil drilling problems, $i d$. at 70.

69. See, e.g., Apple Computer, Inc. v. Franklin Computer Corp., 545 F. Supp. 812, 813-14 (E.D. Pa. 1982), rev'd, 714 F.2d 1240 (3d Cir. 1983) ("Of signal difficulty in this case . . . is the elasticity of the word 'program.' "); Keplinger, supra note 9, at 484-85 ("Much of the confusion and argument over the appropriate legal form of protection for computer software stems from a failure to fully appreciate the consequences flowing from the separability of software into functional components."). 
readable product of these efforts. ${ }^{70} \mathrm{~A}$ more precise use of the term "program" would limit its meaning to source code and machine code (often referred to as "object code"). ${ }^{71}$ Source and machine code are similar in that both are sets of detailed instructions setting forth the order in which the hardware of a computer is to execute its primitive functions im order to carry out a particular task. Source code, however, is a written text in a human-readable computer programming language. ${ }^{72}$ Machine code is the set of electrical pulses that, more or less, correspond to the source code and make the program imstructions "readable" by the computer. ${ }^{73}$ Machine code is not readable by human beings. ${ }^{74}$ In general, only machine-readable forms of programs are

70. A bill, H.R. 6983, 97th Cong., 2d Sess. (1982), was introduced in the House of Representatives by Congressman Kastenmeier on August 12, 1982, that would have amended $\S 101$ of 17 U.S.C. to redefine "computer program" in a more precise way and to define separately several program-related terms, often loosely referred to as mamifestations of programs. The bill did not become law, however, and was not reintroduced in the next session of Congress.

71. The computer program cases tend to refer to "object code" when referring to machinereadable forms of computer programs and often inply-when they do not say so outright-that source code and object code are the only forms to be considered. See, e.g., Apple Computer, Inc. v. Franklin Computer Corp., 714 F.2d 1240, 1243 (3d Cir. 1983). There are, in fact, several intermediate stages possible between source code and the machine-readable code that can be executed. See, e.g., I D. Kuck, The Structure of Computer and Computations 10 (1978). Depending on which hardware and which operating system one uses, object code may be one of those interinediate forms, not the executable form of the program. See, e.g., R. Hunter, The Design AND CONSTRUCTION OF COMPILERS 11 (1981). Because the cases have involved appropriations of machine-readable versions of programs, which may not be the same as their object codes, this article will focus its analysis on what it will call "inachine-readable progranns" or "inachine code." It will refer to machine-readable programs as "object code" only when the terminology of another source under discussion requires use of that term for consistency.

72. The CONTU Final Report defines source and object code as follows: "A source code is a computer program written in any of several programming languages employed by coinputer programmers. An object code is the version of a program in which the source code language is converted or translated into the nachine language of the computer with which it is to be used." CONTU FINAL REPORT, supra note l, at 21 n. 109.

73. It is possible to write a program directly in machine-readable form, but this is rarely done because of the difficulty of writing in machine language. See infra note 74 .

74. In source code form, the ideas of the program, as well as the particularities of the expression of the ideas in the program, will be apparent, that is, capable of being read by someone who understands the language or symbols the program author has used to describe the program. Source code, like poetry, may contaim some abstruse words whose precise ineaning might be open to interpretation by readers of the source code, but whatever content there is in the prograin is there to be discerued. With machine-readable code, neither the ideas nor the expression of the ideas can be "read" in any ineaningful sense by one who has no access to the earhier written form of the program.

Examining an encoded ROM chip with an oscilloscope, see supra note 32 for an explanation of ROM chips, one can detect the presence or absence of the electrical pulses which constitute the machine code. But tnachine code is so unreadable that the Copyright Office cannot even identify whether a particular encoded program is an original work of authorship. See infra note 218 and accompanying text. 
sold, leased, or otherwise made available to the public. ${ }^{75}$ If what one means by "computer program" is a set of instructions that may be used in a computer to bring about a desired result, ${ }^{76}$ one is referrimg only to

Numerous commentators have poimted to the unreadability of object code. See, e.g., Iskrant, supra note 30, at 106 ("The object [code] is not readable by a human in the sense that imformation concerning the program would be conveyed."); Hersey Dissent, supra note 4, at 29 ("IT]he means of expression of the preparatory writing - that which the copyright is supposed to protect-is not to be found in the computer program's mechanical phase."); infra notes 190-94 and accompanymg text. See also D. Hofstadter, Gödel, Escher, Bach: AN ETERnal Golden BRAid 290 (I980):

Looking at a program written in machine language is vaguely comparable to looking at a DNA molecule atom by atom. If you glance back to [a drawing] showing the nucleotide sequence of a DNA molecule-and then if you consider that each nucleotide contains two dozen atoms or so-and if you imagine trying to write the DNA, atom by atom, for a sinall virus (not to mention a human being!)-then you will get a feeling for what it is like to write a complex program in machine language, and what it is like to try to grasp what is going on in a prograns if you have access only to its machime description.

The plaimtiff in Data Cash Sys., Inc. v. JS\&A Group, Inc., 628 F.2d 1038 (7th Cir. 1980), was so certaim that the computer chess game program encoded on the ROM chip could not be "read" that it did not bother to put a copyright notice on it. How unreadable object code is was also illustrated in Williams Elecs., Inc. v. Artic Int'l, Inc., 685 F.2d 870 (3d Cir. 1982). Artic's copying of Williams' program included the copying of a "buried" copyright notice in code. Id. at 876 n.6. Copyright notices have traditionally been intended to provide reasonable public notice of the claim of copyright, see, e.g., 17 U.S.C. $\$ \S 401($ c), 402(c) (1982), not as a trap with which to catch pirates.

75. See, for example, Grogan, Decompilation and Disassembly: Undoing Software Protection, 1 COMPUTER LAW. 1 (1984): "In seeking to preserve a competitive advantage and protect proprietary rights in computer software, many software companies distribute only machine-readable object code copies of their software." The software producer inay provide source code to the purchaser or lessee to enable him to modify the progranı to suit the user's particular purposes or to correct "bugs" in the program. See infra notes 80-81 and accompanying text (explanation of program "bugs").

76. The copyright statute presently defines "coinputer program" as "a set of statements or instructions to be used directly or indirectly in a computer in order to bring about a certain result." 17 U.S.C. § I0I (1982). By its terms, it would seem to apply only to machine-readable code, for only it can bring about results either directly or indirectly (e.g., in conjunction with other programs in the system).

It should be noted that the present statutory definition of "computer program" refers both to "statements" and "mstructions" without defining further what is ineant by these two words. A computer scientist would not quarrel with this statutory definition if proper ineaning were ascribed to the term "stateinents." "Statement" has very precise technical ineaning to a computer scientist, a meaning somewhat different from the ordinary ineaning of the word; within the whole of a set of program instructions, one functional subgrouping of imstructions constitutes a "statement." Computer scientists would not regard as "stateinents" any "comments" that unight have been written by the programmer as part of the source code for the program. Comments are a kind of marginal note the programmer makes to hiunself; the first comment to a program is often the name of the program. "Comments" are for humans; they may serve to reinind, explain, or document something about the program for the programmer, but they are not part of the instructions which will carry out the desired machine function. When the source code is sent through a compiler, see infra notes 78-79 and accompanymg text, the compiler throws away the comments. Comments may reveal nothing of the substance of a program if its drafter so chooses. See infra notes 214-16 and accoinpanying text. One reason why it matters what Congress meant by its use of the term "statement" and whether "comments" were intended to be included is that the Copy- 
machine code.

There are often several phases im the development of an operable computer program. Each phase may be characterized by a different written work. The writings may include: a description of the task or tasks the program is intended to perform; a formulation-im either mathematical or nonmatheinatical terms-of the algorithm ${ }^{77}$ of the program, that is, the programmer's idea about how the task should be

right Office may currently be accepting deposit of "comments" in satisfaction of the deposit requirements for programs. See infra notes 210-19 and accompanying text. "Comments" do not seem to fit within the statutory definition of computer prograin if Congress intended a technical use of the term "statement."

77. A computer program is an instantiation, i.e., an implementation, of an algorithm. Coinputer scientist Donald Knuth states in his well-known book, D. KNUTH, THE ART OF COMPUTER Programming: Fundamentals of Algorithms 4 (1975) (einphasis in original):

The inodern meaning for algorithm is quite similar to that of recipe, process, method, procedure, routine, except that the word "algorithm" connotes something just a hittle different. Besides merely being a finite set of rules which gives a sequence of operations for solving a specific type of problein, an algorithm has five important features . . . .

The first of these features, according to Knuth, is finiteness; that is, an algorithm must terninate after a finite number of steps. The second is definiteness; each step of an algorithm inust be precisely defined and the actions to be carried out unambiguously specified. The third characteristic is input, that is, data to be used to inplement the algorithm. The fourth is output, that is, data that will have a relation to the input as prescribed by the algorithm. The fifth is effectiveness. Id. at 46. "This means that all of the operations to be performed in the algorithm inust be sufficiently basic that they can in primciple be done exactly and in a finite length of time by a inan [or a woman] using pencil and paper." $I d$ at 6.

To aid in the understanding of what an algorithm is, it inay be helpful to give three examples, of the many possible, of an algorithm that could be used to perform one specific task. Assume a list of one hundred numbers that one wants sorted, so that, at the end of the process, all of the numbers will be neatly ordered froin lowest to highest. There are numerous ways to accoinphish such a sort. One method would be to begim at the top of the list of unordered numbers (list A), and work one's way down the hist, first coinparing the top two numbers, keeping the lesser of the two as the provisional minimal number, coinparing this provisional minimum to the third number, and so forth until list $A$ is exhausted. The number yielded from this process will then be the number to place at the top of kist $B$. To get the next lowest number, one repeats the process, and so forth. This is one algorithm for sorting numbers, albeit a rather tedious, cumbersome one.

A second algorithm for the sorting might involve the selection of a unedian number. The first sort through the list of one hundred numbers might put all the numbers lower than the median into one group and all the numbers above that inedian into a second group. Thereafter, one could perform internal sorts of the kind described in the first exainple. For a hist of randoin numbers, this second sorting algorithm would be a faster method than the first.

A third algorithm for the sort might involve creating a set of "baskets" to aid in the sort. One could do an initial sort of the numbers that would throw into "basket" I all those numbers in list A with one digit, into "basket" II all those with two digits, and so on. Once all the numbers are in their respective "baskets," one could sort numbers withm the "baskets" in the manner described in the first example. Of the three algorithms described, this is the one that will be likely to do the sort in the least number of steps.

Assuming that all three algorithms perform the task equally effectively-and remember that these are only three of a multitude of possible sorting algorithms-the algorithm that causes the task to be performed the inost quickly is generally regarded as the superior algorithm. Which algorithm is superior will depend on the nature of the task. Although the third algorithin would be the best algorithm for sorting a set of random numbers, it might not be the superior algorithm 
accomplished; a flow chart that schematically depicts the steps the programmer thinks will be necessary to carry out the algorithm; and the source code, which is a written statement of the precise set of instructions that when transformed into "machime-language" will be capable of producing the desired result in the desired manner. All of these writings are like the plans an architect may draw as a guide to the construction of a house.

The transformation of source code to machine code is accomplished within the computer by processing the source code througli an operating system program known as a "compiler."78 In the transformation process, compiler programs often restructure the set of program mstructions so that the liardware will be able to execute them.79

Once coinpiled into machine-readable form, the program is theoretically able to be executed, that is, to be used in the computer to perform the task for which it was origmally designed. The freshly compiled program may, however, not work. Often, there are errors im the logic of the program-commonly called "bugs"-that must be corrected before the program can be successfully executed..$^{80}$ To locate the

for sorting numbers which have the same number of digits. All algorithms can be described mathematically, as well as in prose.

78. For the sake of simplicity, the text refers only to compilers. There are, in fact, two kinds of prograins, interpreters and coinpilers, that convert into machine code a prograin written in a programming language such as Pascal or BASIC (often referred to as higher level languages). Soine computers have both interpreter and compiler prograns. Most personal computers have only interpreters because of the sinaller anount of memory that is required to store them. A inajor reason to compile a prograun ratlier than interpret it is to produce more efficicnt machincreadable code. Compiled code is many times faster in execution than interpreted code. When one writes source code, one generally does so in a prograinming language adapted either for being interpreted or coinpiled. Most versions of BASIC are designed to be interpreted; Pascal and Fortran are generally designed to be compiled. The basic difference between interpretcrs and coinpilers is that compilers convert the whole prograin at one time whereas interpretcrs in esscnce translate each high level programming language statement in turn into the appropriate sequence of inachine-language instructions. See Toong \& Gupla, supra note 32, at 99.

79. A compiler inay, for example, restructure a task of coinputation which is input as $((3 / 5)$ $\times 4)+((3 / 5) \times 6)$. The compiled output may be structured as follows: $((4+6) \times 3) / 5$. As this example suggests, there will not necessarily be a one-to-one correspondence between the structure of the source code's expression of a particular idea and the structure of the machine-readable expression of it. As indicated supra note 76, another respect in which the source code will differ from the compiled inachine-readable code is that compiler programs discard portions of the source code, such as comments, that are unnecessary for the performance of the task.

80. "If there is even one character out of place in these hundreds of lines [of source code], cliances are the prograin will not work properly. These software 'bugs,' as prograinining mishaps are called, can take weeks to find. One bug in an AT\&T prograin knocked out all long-distance telephone service to Greece in 1979. It was inonths before Ma Bell's programmers pinned down the problem." Golden, supra note 33, at 32. See also B. ARDEN, supra note 32, at 563. The origin of the term "bug" is literal. When investigating the cause of a breakdown of one of the early computers, the machine's engineers found that a moth caught in one of the vacuum tubes liad caused the tube to inalfimction. See R. Pattis, Karel the RoBot 14-15 (1981). 
source of the errors and to correct them almost always takes longer than writing the source code. Specialized programs, known as "debuggers," have been developed to aid in the detection of bugs. ${ }^{81}$ Many programs are marketed before all of the bugs im the program have been worked out, but usually the major bugs are out when the product is sold to the public. Usually, it is the debugged machine-readable version of the program that the so-called "software pirates" appropriate.

Soine programs can be written relatively quickly. Most of the commercially valuable programs on the market, however, required months, and often years, of work. Large or complex programs may cost hundreds of thousands of dollars to develop and de-bug. ${ }^{82}$ A little reflection is necessary to understand why it takes so much time and effort to write a commercially valuable program.

As previously noted, one of the major values of computer programs to society is that they permit very time-consuming-that is, labor-intensive-repetitive tasks to be performed without the need for a human to repeat the myriad steps in the process. ${ }^{83}$ A word processor, for example, allows one to inake changes in a draft without the necessity of having a human retype the whole text. The writer types in the desired changes; the machine prepares a corrected copy. In order for the word processor to be able to perform this and other time-saving functions, the writer of the word processor program must anticipate every function that a user needs to be able to perform, map out how those functions will be organized and how they will interrelate, and then ensure that those functions are carried out by the system in a fast, reliable, and efficient manner. But this is only a part of the task. The programmer must design a system for filing drafts and for retrieving them from memory, must provide for multiple simultaneous uses of the program by many people, and must also interrelate the word processing program with other programs in the computer. ${ }^{84}$ The process of designing a program is time-consuming because it involves thinking out every detail of every function, coordinating them, and putting all those details into programming language. The creative part of writing

81. See B. ARDEN, supra note 32 , at 563.

82. Apple claimed the operating system programs at issue in Apple Coinputer, Inc. v. Franklin Computer Corp., 714 F.2d 1240, 1248 (3d Cir. 1983) had taken 46 man-months, and cost more than $\$ 740,000$, to produce. This figure was said not to include the time or cost of creating or acquiring earlier versions of the programs or the expense of marketing them. $I d$.

83. "What you look for is a repetitive application that is a bother to people and that you can put on a machine and make 10 times easier. It can be anything, anything at all.' " Seneker \& Pearl, supra note 25, at 95 (quoting John Imlay).

84. Soine part of the interface work may be done by the operating system; if not, the programmer will have to include the interface in his word processing program. 
a good program may come in finding a faster, more efficient alternative to an obvious but slower way of performing the function. Thinking of the nonobvious solution may itself be very time-consuming.

In general, the more complicated the task, the inore time it takes to write a program to do it. On complex assignments, a programmer may produce, on an average, only a few words of code a day. ${ }^{85}$ Many programs consist of several thousand lines of code. Others consist of millions. ${ }^{86}$

Prograins are tailor-made to operate only on a particular machine or set of inachines. Programs written for Apple computers, for example, will not operate in IBM or Commodore unachines, unless special coinpatibility instructions are available in either the software or the operating systems of the otler computers. Moreover, programs written for one model of a manufacturer's liardware are not necessarily capable of operating on its other models, although most manufacturers now maximize compatibility among their own models to the extent they $\mathrm{can}^{87}$ The same program written in the same programming language for different machines will, in fact, be a different program. This is so because computer programs are instructions controlling the sequence in which the primitive functions of a particular type of hardware are to be executed.

The tailoring of program to machine is not simply a unatter of knowing which programming language one can use. It also must take into account what primitive functions the liardware can perform and what protocols tle operating system requires, among other things. The adaptation of a program written for one machine so that it can be run on another machine may be nearly as time-consuming as creating the original program. ${ }^{88}$ Unless there is likely to be a substantial demand for software written for many different inachines, software firms are not likely to undertake the modification effort, but will write software whicl works only on the leading manufacturers' machines.

Tle incompatibility of software results in a substantial advantage

85. One study of programmer productivity, cited in F. BROoKs, THE MYTHICAL MAN MONTH 90-91 (1975), indicated that one complex program consisting of only 52,000 words of code had been developed over a four-year period by the efforts of 83 programmers and had required 101 man-years of effort to create. The produetivity of the programmers was, on the average, 515 words per man per year. In other words, the programmers on this task produced only about two good words of code a day.

86. See Iskrant, supra note 30 , at 96.

87. See Patterson, supra note 34 , at 56, regarding IBM's efforts to make its models compatible with one another. See also Compatible Computers, N. Y. Times, Mar. 3, 1983, at D2, col. 1.

88. Microcode can assist in making software for one model compatible with another model. See Patterson, supra note 34, at 56. 
to the more successful hardware manufacturers. ${ }^{89}$ Not only does the availability of a large number of software programs become a prominent feature in the marketing of a successful manufacturer's machines, giving it a competitive advantage in the imitial sale of a machine to a customer, but that firm also has a significant advantage in subsequent sales of computers to the same purchaser since the library of software already accumulated would be unusable if a competitor's incoinpatible machine was purchased. It is not surprising, then, that new entrants and less-successful experienced firms have wanted to copy the systeins software-which is a key to coinpatibility-of their more successful rivals. ${ }^{90}$

\section{The Ease with Which Programs Can Be Copied.}

It is an unfortunate fact that prograins in machine-readable form are as easy and cheap to copy as they are difficult and expensive to develop and refine. There are presently three major media for the storage of programs in machine-readable form: tapes, disks, and silicon chips.91

If the program a software pirate wants to copy is on a tape or disk, all the pirate needs to do is take an enpty tape or disk and insert it in a computer which will autonatically replicate the coded pulses of the program and store tlem on this new mediuin. ${ }^{92}$ This can be done in much the same way as one would make a tape recording of one's favor-

89. "Much of Apple [Computer, Inc.'s] success is attributed to the company's policy of encouraging vendors of software and peripheral equipment to develop and sell products that are compatible with Apple Computers. For example, more than 11,000 apphcation programs are available for Apple Coinputers, 95\% of thein developed by independent vendors." Toong \& Gupta, supra note 32, at 102 . Time Magazine estimated that about 16,000 software programs were available for the Apple II. It estimated that there were only about 1000 available for the IBM PC. Fafflick, supra note 37 , at 37.

90. This was the basis of one of Franklin's defenses in Apple Computer, Inc. v. Franklin Computer Corp., 545 F. Supp. 812 (E.D. Pa. 1982), rev'd, 714 F.2d 1240 (3d Cir. 1983). Franklin argued that for Apple software to be $100 \%$ compatible with the Franklin machine, appropriation of Apple's operating system would also have been necessary. 545 F. Supp. at 814-15. Apple mtroduced evidence that other Apple-compatible operating systems existed. 714 F.2d at 1245 . Although in the future it is possible that standardization-and hence maximal compatibilityrather than differentiation (or noncompatibility) will be the rule as to hardware, this may be wishful thinking, given the advantages of noncompatibility for leading hardware manufacturers. At any rate, it is clearly not the rule at present.

91. See, e.g., B. ARDEN, supra note 32, at 357-64. Other storage media-punched cards, for exainple-have been used in the past, but have fallen out of fashion because of their unreliability, bulkiness, and slower speed in operation.

92. "[M]ost computers imclude utility programs making it possible for even a novice to unake an exact electromic backup copy of almost any commercially available program." $\mathrm{N}$. $\mathrm{Y}$. Times, Feb. 24, 1983, at D2, col. 1 . 
ite record. The cost of disks and tapes is minimal..$^{93}$ No specialized equipment is necessary. Each copy can be made in a matter of seconds and can be used in exactly the same way as the origmal tape or disk. There are no limits to the number of copies that can be produced in this manner.

If the program is mstead on a silicon chip, the pirate will not even have to find a chip with the same circuitry as the chip to be copied. The digital code embodied in a chip can be transferred to tapes or disks, as well as to other chips. If one wants to mass-produce chips with the same program on them, one may need specialized facilities. A stencil of the coded patterns on the chip can be placed over the face of a blank chip, and used to imprint the pattern on the new chip. ${ }^{94}$ But anyone with a chip manufacturing facility will have the necessary equipment, and anyone with a few thousand dollars can buy the chips and the equipment to make such copies. A stencil can be prepared in a mattcr of days. The imprintation on the chip takes an instant. As with disks, copied chips may be used as readily as the originals for the purposes the program was designed to perforin. There is an even easier and less expensive way to copy programs than those already described. If one can gain access to a system that has the desired program on file, one can call for that file and have a copy of it transferred to one's own computer. ${ }^{95}$ Simce the reproductions of tapes, disks and chips may be identical to the copies from which they were made, it may be difficult, if not impossible, to detect whether a given tape, disk or chip is an unauthorized copy of the program. ${ }^{96}$

\section{E. The Threat of Software Piracy.}

So great is the cost of developing a marketable computer program and so little is the cost of copying it exactly, that, not surprisingly,

93. Software disks sell for about $\$ 2$ each at wholesale. (Programs sold on them may sell for as much as $\$ 495$ each.) See Seneker \& Pearl, supra note 25 , at 93 . The wholesale cost for large blank tapes is about $\$ 50$ each. See Seneker, The Growth Industry's Growth Industry, Forbes MAG., July 6, 1981, at 142.

94. For a description of the process of manufacturing chips, see Boraiko, supra note 32, at 426-34.

95. See Bosworth, Hardware and Software-What Are They?, UNIVERsity of Southern California law Center Fourth Annual Computer Law Institute 1 (1983) (heremafter cited as COMPUTER LAW INSTITUTE]. "Software can be seut over communication lines from one computer to another, this is called downline loading." Id. at 13. It may be possible, however, to trace the transfer of the file from the central computer to the home computer.

96. If the copyright owner does not sell programs on that particular brand of medium, it may be possible to ascertain that a particular copy is contraband. 
software piracy has become widespread.97 To appreciate just how much of a threat this piracy may be to the legitimate software industry, one need only review a few basic facts.

Millions of computers are used in the United States. In 1982 an estimated 2.8 million personal computers were sold in the Uinted States. ${ }^{98}$ Another five million were expected to be sold in $1983 .{ }^{99}$ Some estimate that by the end of the century there will be 80 million personal computers in use. ${ }^{100}$ All of these computers need programs to perform useful functions. As one commentary has noted, "software ... is to computers what blades are to razors." 101 Coniputers only have value to their owners to the extent there are application programs -word processors, video games, balance sheet projections - to be run on them. Most computers now have the capability of operating a large number of programs. ${ }^{102}$

The demand for computers creates a demand for software. As 1might be expected, the current market for software is thus very large and is expected to grow dramatically in the next five to ten years. Estimates of total software revenues for 1982 run as high as $\$ 45$ billion, of which $\$ 3.1$ billion was for sales of packaged software. ${ }^{103}$ For 1983, packaged software sales are expected to be more than $\$ 7$ billion. ${ }^{104}$ By 1987, packaged personal computer software sales alone are expected to

97. See, e.g., Playing Hardball with Software, SCIENCE '83, May 1983, at 66; Piracy in Era of Computers, N. Y. Times, Feb. 24, 1983, at D2, col. 1; Getting Tough on Software Theft, Business WeEk, May 31, 1982, at 28; Secrets of the Software Pirates, Esquire MAG., Jan., 1982, at 58.

98. Friedrich, A New World Dawns, Time MAG., Jan. 3, 1983, at 14.

99. Seneker \& Pearl, supra note 25, at 93 . The total computer sales for 1983 were expected to be more than $\$ 24$ billion, of which about $\$ 6.5$ billion would go for personal computers. Manuel, U.S. Markets: Data Processing and Software, ELECTRONICs MAG., Jan. 13, 1983, at 132.

100. Friedrich, supra note 98 , at 16 . Microcomputer sales are expected to reach $\$ 15$ billion by 1987. Getting Tough on Software Theft, supra note 97, at 29.

101. Seneker \& Pearl, supra note 25, at 93.

102. The number of programs any particular computer can have stored in its internal memory is limited. The availability of supplementary memory devices such as disks, however, means that the machme's internal memory storage capacity can be easily augmented.

103. Manuel, supra note 99 , at 133 . Software revenues include not only sales of prepackaged software, but revenues from customized software, froin leased software, and from inaintenance of these products and services. The growth in the software industry is evident by comparing the 1982 figures with the 1980 figures. Total software revenues in 1980 have been estimated at $\$ 13$ billion of which $\$ 3.6$ billion were for sales of packaged software. See Seneker, supra note 93, at 143 .

104. More than $\$ 1$ billion will be for application programs and more than $\$ 4$ billion for operating systems. Manuel, supra note 99 , at 133 . One research analyst thinks the microsoftware market is growing by $43 \%$ a year, see Seneker \& Pearl, supra note 25 , at 93 ; another estimates growth at $57 \%$ a year, id. One software directory that has aimed to be comprehensive lias identified 21,000 microsoftware packages for sale from 2900 different sources. Id. at 94 . Entry into this market is relatively easy, especially for microsoftware packages, because of low capital costs. Id. The number of new entrants to the field can reasonably be expected to continue to grow as long as the computer boom lasts. See CONTU FINAL RePORT, supra note 1, at 23-24. 
reach $\$ 4.8$ billion. 105

The amount of piracy in this rapidly expanding market is difficult to estimate with any precision. One analyst has estimated that thirty percent of software industry revenues are lost to piracy. ${ }^{106}$ It is a major problem in the industry. Preoccupation with the problem of piracy, however, should not obscure the difficulties of using copyright to solve the problem. That copyright is helpful in checking some forms of piracy does not mean it is appropriate for checking all of thein. There may be other, more effective, ways to control piracy; 107 moreover, they may be more appropriate than copyright to protect machine-readable programs.

\section{Why Copyright Was Perceived to Be a Solution to the Problem of Legal Protection for Computer \\ Programs: Copyright Office Practice, CONTU, AND CONGRESS}

\section{A. Copyright Office Practice.}

When the issue of the copyrightability of computer programs first arose, ${ }^{108}$ the Copyright Office had profound doubts about the concept-some of which were statutory and some of which were constitutional. ${ }^{109}$ Under its "rule of doubt," 110 the Office decided, in 1964, to

105. Getting Tough on Software Theft, supra note 97, at 29.

106. Battling the Computer Pirates, N. Y. Times, Jan. 5, 1983, at D1, col. 3. One company whose annual sales are $\$ 26$ million estimates its losses due to piracy at $\$ 20$ million to $\$ 40$ million a year. Id. "Some software producers estimate that half their sales are lost to illegal copies." Getting Tough on Software Theft, supra note 97, at 28. The publislier of the magazine Softalk has said, "I don't know anyone with a personal computer who doesn't liave about $\$ 500$ wortli of free [pirated] software.' " Playing Hardball with Software, supra note 97, at 66, 67-69.

107. Efforts are underway to try to check piracy by technological means, for example, by making software which will operate only on the purcliaser's computer. See N. Y. Times, Feb. 24, 1983, at D2, col. 1. See also Playing Hardball with Software, supra note 97, at 67-69; Kolata, Scheme to Foil Software Pirates, 221 Science 1279 (1983). The problem with this type of solution is its restrictiveness. A proposal of the sort set forth infra notes $464-92$ and accompanying text may be more satisfactory to the imdustry, perliaps making this restrictiveness umecessary.

108. Cary, the Deputy Register of Copyrights in 1964, reports that the issue first arose in 1961 when an aviation company deposited a copy of a computer tape for registration witl the Copyright Office. See Cary, Copyright Registration and Computer Programs, 11 Bull. Copyright Soc'y 362, 363 (1964).

I09. The statutory doubt was whether machine-readable versions of programs were "copies" of programs within the meaning of that term under the 1909 Act as it lad been interpreted by the courts. Under White-Smith Music Publishing Co. v. Apollo Co., 209 U.S. 1, 17 (1908), copyright protection was said to extend only to "copies which were perceptible to humans-things written or primted . . . in intelligible notation." The constitutional doubt was whetler machime-readable versions of programs could be considered the "writmgs of an author" within the meaning of the phrase in the enabling clause of the Constitution. U.S. CoNST. art. I, § 8, cl. 8. See infra note I81 and accompanying text. But see CONTU FINAL REPORT, supra note 1, at 15. 
permit registration of programs as long as certain conditions were met, ${ }^{11}$ leaving the ultimate question of copyrightability to the courts. ${ }^{112}$ Between 1964 and the enactment of the copyright revision statute in $1976,{ }^{113}$ about 1200 programs, most of which were owned by major corporations such as IBM, were registered with the Copyright Office. 114 This was a very small proportion of the programs estimated to have been written during that saine period. ${ }^{115}$ The copyrightability of machine-readable forms of programs does not seem to have been questioned im any hitigation prior to the enactment of the copyright revision law. ${ }^{116}$

\section{B. The 1976 Revision of the Copyright Law.}

By the time the Copyright Office promulgated its policy on registration of computer programs, Congress had already begun the inassive task of revising the federal copyright law. ${ }^{117}$ Although the twenty-year process of revision generated a great many reports and led to a great

110. See Cary, supra note 108, at 365 ("This doubt was such that the office considered it justifiable to resolve the doubt in favor of registration, in keeping with its policy of giving the apphicant the benefit of the doubt wherever possible.").

111. The office first announced its willingness to accept programs for registration in May, 1964. See CONTU FINAL REPORT, supra note 1, at 82 . The prerequisites were (1) the work had to contain sufficient original authorship to be copyrightable; (2) the work had to be published with a copyright notice; and (3) the copies of the program submitted for registration had to be in human-readable (as contrasted with inachine-readable) form (i.e., source code, not object code). Id.

112. See Cary, supra note 108, at 363 ("The resulting decision [to accept programs for registration] is not, of course, to be interpreted as constituting a judicial holding that a computer program is in fact a 'writing' of an author. It is inerely an administrative decision that, based upon existing judicial precedents and statutory law, the courts might agree that it was a writing in the constitutional sense.").

113. The Copyright Act of 1976, Pub. L. No. 94-553, 90 Stat. 2541 (codified as anended at 17 U.S.C. (1982)), was enacted on October 19, 1976. Most of its provisions became effective on January $1,1978$.

114. CONTU Commissioner Hersey observed that only 1205 programs had been registered between 1964 and January 1, 1977. Hersey Dissent, supra note 4, at 34. Hersey noted that 971 of the 1205 registered programs (80\%) were owned by two comparies-IBM and Burroughs Corp. Id.

115. Hersey cited estimates that a million programs a year had been developed. Id.

116. The CONTU Final Report states that the "Register's 1964 determination has never been challenged." CONTU FINAL REPORT, supra note 1, at 16. Subsequent to the issuance of that Report, one case applied the 1909 Act to hold that machine-readable versions of computer prograins were not copyrightable subject inatter. See Data Cash Sys., Inc. v. JS\&A Group, Inc., 480 F. Supp. 1063 (N.D. Ill. 1979), aff'd on other grounds, 628 F.2d 1038 (7th Cir. 1980). The CONTU Report concedes that under the 1909 Act inachine-readable programs may not have been protectible by copyright. See CONTU FINAL REPORT, supra note 1, at 7-8.

117. The revision of the copyright laws began in 1955 when Congress appropriated funds for a comprehensive study of needed changes in the law. See CONTU FINAL REPORT, supra note 1, at 3. 
many hearings on a great many issues, ${ }^{118}$ the copyrightability of computer programs does not seem to have been among them. ${ }^{11}$ There is some legislative history that suggests Congress contemplated that the revised statute would extend to programs, ${ }^{120}$ although, as enacted, the statute itself is silent about computer programs; there is also legislative history suggesting that Congress's decision to defer decision on some coinputer-related matters included the copyrightability issue. ${ }^{121}$ Whatever nnystery might have existed as to whether computer programs in machine-readable form were within the reach of the copyright statute was, however, resolved in December, 1980, when Congress amended the copyright law to make explicit that programs were copyrightable, thereby adopting the CONTU recommendations. ${ }^{122}$ Without questioning the integrity or diligence of the CONTU Commissioners who favored recommending that copyriglit protection be available for inachine-readable forns of programs, we may question whether the Commission's conclusions were warranted. It is possible to ask whether Congress was fully informed of the implications of the decision before it was made and whether Congress might have acted differently if the inforination provided to it had been more complete and if otler alternatives had been explored by CONTU.

\section{CONTU's Mandate from Congress.}

The major reason why Congress began thinking of creating the Commission on New Technological Uses of Copyrighted Works was because it was having difficulty resolving one highly controversial issue. So contentious was the debate and lobbying on the issue that it was among the matters delaying enactment of the whole copyright revi-

118. See, e.g., House Comm. on the Judiciary, 87th Cong., Ist Sess., Copyright LaW Revision (Comm. Print 1961); CopYright Soc'Y OF THE U.S.A., StUdies ON Copyright (1983); Gorman, An Overview of the Copyright Act of 1976, 126 U. PA. L. Rev. 856 (1978); Symposium: The Copyright Act of 1976, 24 UCLA L. REv. 951 (1977).

119. Since the Copyright Office had been so unsure of the constitutional and statutory implications of the extension of copyright protection to prograns, it is curious that the issue did not excite more congressional attention. However, CONTU's Final Report is the only congressionally authorized study of the inatter.

120. See H.R. Rep. No. 1476, 94th Cong., 2d Sess. 51, 54 (1976) thereinafter cited as HousE REPORT]. The text of these references inay be found infra at note 132.

121. See infra note 131.

122. Pub. L. No. 96-517, 94 Stat. 3007 (1980) (codified at 17 U.S.C. $\S \S 101,117$ (1982)). As mentioned supra note 9, these amendinents were appended to a bill to ainend the patent and trademark law; the legislative history as to the copyright amendineuts is sparse. The recommendations of the Commission may be found in the CONTU Final Report, supra note 1, at 1-2. 
sion package. ${ }^{123}$ The issue was whether the owner of a copyrighted work-such as a book-should be given the exclusive right to control the encoding of his or her work in an electronic form for storage and use in a coinputer or whether the copyright owner's exclusive rights ought to be limited to the inanufacture and distribution of "hard" copies of the work. ${ }^{124}$ Congress was mindful of speculations that hardcopy distribution of books, journals and the like might dimimish substantially, or perhaps even cease, and might be replaced with huge memory banks contaming coinputerized copies of these works that each reader with access to the nieinory bank could "call up" and read or duplicate at will. ${ }^{125}$ Book pubhishers understandably were concerned about the financial imphications of this, as were librarians and educators. ${ }^{126}$ The same groups were also intensely concerned about another controversial new technology issue, the photocopying of hardcopy materials, which inore immediately affected their interests than did the coinputerized data base issue. ${ }^{127}$ Congress decided to include representatives of these groups on the Commission. ${ }^{128}$ The

123. See, e.g., R. Saltman, Copyright in Computer-Readable Works 27 (1977); CONTU FINAL REPORT, supra note 1, at 39 n.163. CONTU was first proposed in 1967. See $\mathrm{S}$. 2216, 90 th Cong., 1st Sess., 113 Cong. Rec. 20,694 (1967).

124. R. Saltman, supra note 123 , at 1 .

125. Id.

126. Id.

127. Id. at 23-26.

128. The Congress declared that CONTU should have four members representative of the interests of authors and publishers; four representative of the interests of users of works (primarily libraries and educatioual institutions); and four representative of the public imterest generally (one was specifically to be a consumer protection expert). Pub. L. No. 93-573, § 202(a), 88 Stat. 1873, 1874 (1974). The thirtcenth member of CONTU was to be the Librarian of Congress. Id.

President Ford appointed the following persons to the Commission:

-As representatives of the imterests of authors and publishers:

1) John Hersey, novelist and journalist;

2) Dan M. Lacy, seuior vice presideut of McGraw Hill, Inc.;

3) E. Gabriel Perle, Vice-President-Law, Time, Inc.;

4) Hershel B. Sarbin, Executive Vice President, Ziff-Davis Publishing Co.

-As representatives of the imterests of users:

5) William S. Dix, Librarian Eıneritus, Princeton University;

6) Arthur R. Miller, Professor, Harvard Law School;

7) Robert Wedgeworth, Executive Director, American Library Association;

8) Alice Wilcox, Director of Mimitext.

-As representatives of the public interest:

9) Stanley H. Fuld, fornerly Chief Judge of the New York Court of Appeals (appointed Chair of the Commission);

10) George D. Cary, retired Register of Copyrights;

11) Melville B. Nimmer, Professor, U.C.L.A. Law School (appointed Vice-Chair);

12) Rhoda H. Karpatkin, Exccutive Director, Consumers Union.

Daniel J. Boorstin, the Librarian of Congress, and Barbara Ringer, the Register of Copyrights, were ex officio members of the Commissiou.

CONTU Final Report, supra note 1, at 4-5. 
copyrightability of computer programs was not named explicitly as an issue to be studied, but it was certainly an unresolved new technology issue. ${ }^{129}$

In addition to establishing CONTU to study the computer-related and photocopy issues, ${ }^{130}$ Congress decided to put an interim section 117 in the copyright revision bill to preserve the status quo-whatever that was-as to the coinputer-related issues. ${ }^{131}$ Whether the copyrightability of computer programs in machine-readable form was among the computer-related issues specifically deferred by Congress in interim section 117 is somewhat unclear; nost courts whicl have addressed the issue lave said they were. ${ }^{132}$

129. See supra notes 108-21 and accompanying text.

130. The bill establishing the Commission was passed in December, 1974. See supra note 1. Section 201(b) of Pub. L. No. 93-573, 88 Stat. 1873, 1874 (1974), directed the National Commission on New Technological Uses of Copyrighted Works to study

(1) the reproduction and use of copyrighted works of authorship-

(A) in conjunction with automatic systems capable of storing, processing, retriev$\mathrm{mg}$, and transferring imformation, and

(B) by various forms of inachine reproduction, not including reproduction by or at

the request of imstructors for use in face-to-face teaching activities; and

(2) the creation of new works by the application or imtervention of such automatic systems of machine reproduction.

Section 201(c) directed the Commission to make recommendations as to changes in copyright law or procedures as may be neccssary to assure access to copyrighted works and recognition of the rights of copyright owners. Id.

131. "Section 117 was agreed upon by interested parties as a means of permitting passage of the revision bill without committing Congress to a position on the computer-related issue until inore study could be undertaken." CONTU FiNAL REPORT, supra note 1, at 39 n.163. Section 117 was first imtroduced into the copyriglt revision bill in 1969, S. 543, 91st Cong., lst Sess., 115 CONG. REC. 1382 (1969); CONTU FINAL REPORT, supra note 1, at 39 n.163, and was enacted as a part of the Copyright Revision Act of 1976 on October 19, 1976. The eniginatic interim $§ 117$ states:

Notwithstanding the provisions of sections 106 through 116 and 118, this title does not afford to the owner of copyright in a work any greater or lesser rights with respect to the use of the work in conjunction with automatic systems capable of storing, processing, retrieving, or transferring imformation, or in conjunction with any similar device, machine, or process, than those afforded to works, under the law, whether title 17 or the common law or statutes of a state, im effect on December 31, 1977, as held applicable and construed by a court in an action brought under this title.

17 U.S.C. § 117 (1976), repealed by Pub. L. No. 96-517, 94 Stat. 3019, 3028 (1980).

132. Despite the apparent relation of these three developinents-passage of a statute silent about computer programs, imclusion of a "hold fast" provision, and the establishment of CONTU - the extent of their interconnection lias not been at all clear. Had Congress intended to mclude machine-readable forins of programs within the reach of the 1976 Act? Had section 117 been imtended to freeze the law only as to the encoding of hard-copy works, or was it meant to freeze the law as to the copyrightability of inachine-readable prograins as well? Was the cstablishment of CONTU a decision to defer decision on this copyrightability issue until CONTU had had a chance to study it as well as the issue of coinputerization of hard-copy materials? The CONTU majority regarded the legislative history of the 1976 Act as unanbiguously in favor of copyrigltt protection for maclime-readable forms of programs. CONTU FINAL REPORT, supra note 1, at 16. Otlers, cited infra, lave interpreted the 1976 Act as unambiguously deferring the decision. 
Curiously, the computer issue that brought about the creation of CONTU does not seem to have caused any controversy within the

CONTU relied on two references to programs in one of the House reports on the copyright revision bill to support its conclusion. The two references are as follows:

The history of copyright law lias been one of gradual expansion in the types of works accorded protection, and the subject matter affected by this expansion has fallen into two general categories. In the first, scientific discoveries and technological developments have made possible new forms of creative expression tliat never existed before. In some of these cases the new expressive forms-electronic music, filmstrips, and computer prograins, for example-could be regarded as an extension of copyrightable subject matter Congress lad already intended to protect, and were thus considered copyrightable from the outset without the necd of new legislation. In other cases, such as photographs, sound recordings, and inotion pictues, statutory enactment was deemed necessary to give them full recognition as copyrightable works.

HOUSE REPORT, supra note 120 , at 51.

The term "literary works" does not connote any criterion of literary merit or qualitative value: it includes catalogs, directories, and similar factual, reference, or instructional works and compilations of data. It also includes computer data bases and computer programs to the extent that they incorporate authorship in the programmer's expression of original ideas, as distinguislied from the ideas themselves.

Id. at 54. (CONTU did not point out that the Senate Report on the copyright revision bill did not include the same explicit reference to computer programs as literary works. See Nimmer, The Subject Matter of Copyright Under The Act of 1976, 24 UCLA L. REv. 978, 994-95 (1977).) Yet the 1976 Act was sufficiently ambiguous to cause CONTU to recommend that the copyright law be amended to make explicit that machine-readable forms of programs were within the purview of copyriglit. See CONTU FINAL REPORT, supra note 1 , at 1 .

The fact that CONTU derived its mandate to study the copyrightability of machine-readable forms of programs from the same portion of Pub. L. No. 93-573, 88 Stat. 1873, 1873 (1974), that directed CONTU to study the "use of copyrighted works . . . in conjunction witl automatic systems capable of storing, processing, retrieving and transferring information"-terms that track very closely those in imterim $\S 117$-supports the argument of congressional deferral of decision on the matter. Cf. CONTU FINAL REPORT, supra note 1 , at 9.

Further evidence of the ambiguity of the legislative history of the 1976 Act is found in a reference im a congressioual report to machine-readable versions of programs as perliaps not being "fixed" enough to qualify for copyright protection. That report states: "[T]he definition of "fixation' would exclude from the concept purely evanescent or transient reproductions sucl as those projected briefly on a screen, shown electronically on television or other catlode ray tube, or captured momentarily in 'memory' of a computer." HOUSE REPORT, supra note 120, at 53. CONTU dealt with this bit of legislative history by arguing that it was mcorrect about fixation and, therefore, could be ignored; the statutory definition of "fixed" was unambiguous, making perusal of the legislative history unnecessary. CONTU FINAL REPORT, supra note 1, at $22 \mathrm{n} .111$.

Many who have found that the 1976 Act did not speak to the copyrightability issue lave cited the passage of an intcrim $\$ 117$ and the decision to establish CONTU in support of their arguments. See, e.g, Hersey Dissent, supra note 4, at 31. Commissioner Hersey acknowledged that there were in the voluminous legislative history on the copyright revision bill a few passing references to computer programs which seemed to assume their copyrightability, but to him the $\S 117$ moratorium "imdicate[d] beyond a doubt that Congress has not reaclied the point of clear intention." Id.

In several court decisions since the CONTU Final Report, the interim $\$ 117$ has been interpreted as an expression of Congress's decision to defer decision on the copyrightability issue as to machine-readable programs. The district court in Data Caslı Sys., Inc. v. JS\&A Group, Inc., 480 F. Supp. 1063, 1067 (N.D. Ill. 1979), affd on other grounds, 628 F.2d 1038 (7th Cir. 1980), interpreted $\& 117$ as requiring it to apply the rules under the 1909 Act to the copying of a program encoded on a chip: "The legislative listory for section 117 explams that this section was enacted because the problems in the area of computer uses of copyrighted works are not sufficiently devel- 
Commission. ${ }^{133}$ CONTU was unaninuous in its conclusion that inserting and storing a copyrighted work as part of a computerized data base was making a copy within the meaning of $\S 106$ of the new law and would, unless authorized, infringe the copyright. ${ }^{134}$

The issue that generated heated controversy within the Commission was the copyrightability of programs in machine-readable forn.

oped for a definitive legislative solution. Thus, the purpose of $\S 117$ is to preserve the status quo." The court also noted that CONTU had been established to deal with these problems. Id. at 1067 n.5. The court in Apple Computer, Inc. v. Franklin Computer Corp., 545 F. Supp. 812 (E.D. Pa. 1982), rev'd, 714 F.2d 1240 (3d Cir. 1983) (reversal based on 1980, not 1976 law), stated, "Congressional intent regarding the copyrightability of objeet codes and ROMs is not clear. The 1976 Act left intaet the case law developed under the 1909 Act." 545 F. Supp. at 819 n.9. It also noted that "CONTU was established in 1974 to make recommendations to Congress concerning the copyrightability of computer software and programs." $545 \mathrm{~F}$. Supp. at $817 \mathrm{n} .17$. The court in Apple Computer, Inc. v. Formula Int'l, Inc., 562 F. Supp. 775, 779-80 (C.D. Cal. 1983), although finding that under the 1980 amendments the inachine-readable programs were copyrightable, viewed the legislative history of the 1976 Act as reflecting prior indecisiveness on this issue. It pointed to interim $\S 117$. "Section 117 specifically preserved the preexisting state of the law as to copyrightability of computer programs without clearly defining what the preexisting law was. The status quo was preserved pending further study and decision by Congress." Id. at 779. See also Midway Mfg. Co. v. Artic Int'1, Inc., 704 F.2d 1009, 1012 (7th Cir. 1983) ("The language and legislative history of the 1980 amendment are convincing that original section 117 was intended only to leave unaltered the existing law governing the exclusive rights of owners of copyrights in computer programs."). The Midway Manufacturing court made this remark in rejecting the defendant's arguunent that $\S 117$ required resort to the 1909 Act and common law to determine whether circuit boards can be copies of an audiovisual work such as a videogame. Cf. Apple Coinputer, Inc. v. Franklin Computer Corp., 714 F.2d 1240, 1247 (3d Cir. 1983) (stating that the legislative history of the 1976 Act "suggested" that programs vere considered copyrightable as hiterary works but noting that $\S 117$ was added to preserve the status quo until CONTU finished its deliberations and made its report).

One court, Tandy Corp. v. Personal Micro Computers, Inc., 524 F. Supp. 171, 174 (N.D. Cal. 1981 ), has said that the interim $\$ 117$ pertained only to the controversial issue of "imputting" works otherwise found in hard copy into computer inemory. One must examine the language of $\$ 117$ closely to derive even this ineaning from it. The language is certainly not narrow enough to cover only this situation and no others. Since a source-code version of a computer program, just like any other hard-copy material, must be "mputted" into the computer-that is, must be transformed into unachine-readable form-it would have to be treated as within the reach of $\S 117$ just as other hard-copy material. The copyrightabihity of the source-code program thus would be as secure as the copyright in a book put into a computer's memory storage. But the electronic version of a computer program-whether "used" in the sense of being "imput" and stored in a computer inemory, or in the sense of being processed through the computer-was not something whose copyright implications Congress had settled, having left this to CONTU.

133. Only four paragraphs of the CONTU Final Report were devoted to discussion of it. Sec CONTU FINAL REPORT, supra note 1, at 39-40. There were no dissents to the Commission's recominendation on this poimt. Id. at 1 .

134. "[T]he provisions of the new copyright law offer appropriate and sufficient guidance to determine what acts create copyright liability in this area. The protection afforded by section 106 of the new law seemingly would prohibit the unauthorized storage of a work within a computer meinory, which would be merely one form of reproduction, one of the exclusive rights granted by copyright." Id. at 39 . CONTU thought no change in the statute would be necessary to recognize this, id., except, of course, the repeal of the interim $\S 117, i d$. at 12. 
Even as to this issue, the Commission unanimously agreed that computer programs in machine-readable form deserved some form of legal protection. ${ }^{135}$ Several Commissioners, however, doubted whether copyright was the proper ineans to protect these prograins. ${ }^{136}$

\section{CONTU on Copyrightability of Machine-Readable Programs.}

The issue of the copyrightability of machine-readable forms of computer programs was not one on which the Commissioners had any special expertise. ${ }^{137}$ There were no computer scientists, no software or hardware industry representatives, nor any users of complex software systems on the Commission. Because Congress had decided that the coinposition of the Commission should reflect the interests of groups concerned about the computerization of hard-copy works and about photocopying, ${ }^{138}$ this is not surprising. It was, however, unfortunate, for the issue the Commission was to decide was of the utmost importance, and the Commissioners themselves were not well equipped to take on the task.

A subcommittee of three Commissioners focused its attention on the software protection issue. ${ }^{139}$ They unanimously favored copyright protection for computer programs. Their argument on the copyrightability of programs is worth studying, for it was carefully constructed to inake it seem that copyright was indubitably the correct legal form, when, in fact, it is not. The argument began with a grand sweep from the Renaissance through the Industrial Revolution during which "technological developments [had] consistently extended society's power to control natural phenomena and to shape its own destiny." 140 Now society was experiencing an Information Revolution in which "[n]ew means of communication [were] transcend[ing] words

135. CONTU FINAL REPORT, supra note 1 , at 12.

136. At least four Commissioners had serious reservations about the chosen means. See supra notes 4-5 and accoinpanying text regarding the dissenting opinions and others with reservations about the majority proposal.

137. One of the Commission members, Professor Arthur Miller, had eight years earher written one short article on computers and copyright law. See Miller, Computers and Copyright Law, 46 Mich. St. Bar J. 11 (1967). Another of the Commissioners, George D. Cary, had been the Register of Copyrights at the time the Copyright Office had decided to permit registration of computer programs.

138. See supra notes 123-28 and accompanying text regarding the composition of the Commission.

139. The software protection subcommittee consisted of the Commission Chairman Stanley Fuld, Professor Arthur Miller, and a Tine, Inc. executive, Gabriel Perle. The Commission had three other subcommittees: one on photocopying, one on data bases, and one on computer-created works. CONTU FINAL REPORT, supra note 1, at 6.

140. Id. at 9. 
fixed on paper or images on film and permit[ting] authors to communicate creatively, adaptively, and dynamically with their audience." 141 Digital computers and their prograins were a central part of this Revolution. ${ }^{142}$ The social desirability of utilizing computers to free huinans from mundane tasks was evident. ${ }^{143}$

Because computers had become more widely available, because they had become able to use many different programs, 144 and because prograins were easy to rephicate, a concern about legal protection for programs was emerging. ${ }^{145}$ It was evident to CONTU that if program authors were to have the incentive to create and disseminate their works, there must be adequate legal protection for their product. ${ }^{146} \mathrm{~A}$ critical reader might be willing to agree with these notions, but at the same time might observe that none of this addressed the appropriateness of copyright as a form of legal protection for machine-readable prograins.

CONTU then observed that the "universe of works protectible by copyright [had] expanded along with the imagmation, communications media, and technical capabilities of science."147 Many of the statutory emendations that had added new categories of works to the copyright realm had been intended to accommodate new teclmological develop-

141. $I d$.

142. Id. Computer programs as a new form of "writing" are discussed briefly at this point in the CONTU Final Report.

143. "For both economic and humamitarian reasons, it is undesirable for people to carry out manually the process described in painstaking detail in a computer program. Machines, lacking human attributes, cannot object to carrying out repetitious, boring and tedious tasks." Id. at 10.

144. What CONTU said was that "programs have become less and less frequently written to comply with the requirements imposed by a single-purpose machine." Id. at 10 . This is true, but it does not, as some readers might think, necessarily imply that programs written for one machine will work on others. See supra notes 87-89 and accompanying text.

145. CONTU FINAL REPORT, supra note 1 , at 10.

146. CONTU reminded the reader that this principle was the basis of copyright law. It posited that computer programs would only be disseminated if

1. the creator may recover all of its costs plus a fair proflt on the first sale of the work, thus leaving it unconcerned about the later publication of the work; or

2. the creator may spread its costs over multiple copies with some forn of protection against unauthorized duphication of the work; or

3. the creator's costs are borne by another, as, for example, when the government or a foundation offers prizes or awards; or

4. the creator is indifferent to cost and donates the work to the public.

CONTU FINAL REPORT, supra note 1, at 11. CONTU recognized that the third and fourth possibilities were rare in this country and thus might not provide the broad incentive nceded to produce programs. The first would cause program prices to be so high that there would be a reduction in the number of programs marketed. The second was the copyright solution which appealcd to the majority of the commissioners.

147. Id. at 11 . 
ments. ${ }^{148}$ Since copyright had been expanding all along, its expansion to cover programs in machine-readable form seeined to the CONTU majority to be a part of a natural progression. ${ }^{149}$ That relatively few statutory changes in the copyright law would be needed to inake appropriate accommodations for computer programs also seeined to demonstrate the suitability of copyright. 150

The inadequacy of other forms of legal protection for machinereadable forms of prograins was another factor that persuaded CONTU of the importance of protecting them through copyright. Supreme Court cases had questioned the patentability of computer programs. ${ }^{151}$ Trade secret law and the common law of inisappropriation

148. Id. at 15. The constitutional term "writings," the CONTU majority noted, had a "broad and dynamic meaning" that could be seen in the variety of work that had been found to be constitutionally copyrightable. Id. at 14 .

149. CONTU viewed copyright as appropriately balancing the author's interests, the user's interests, and the public interest:

To provide reasonable protection for proprietors without unduly burdening users of programs and the general public, the following statements concerning program copyrights ought to be true:

1. Copyright should proscribe the unauthorized copying of these works.

2. Copyriglt should in no way inhibit the rightful use of these works.

3. Copyright should not block the development and dissemination of these works.

4. Copyright should not grant anyone more economic power than is necessary to achieve the incentive to create.

Id. at 12.

150. CONTU recommended three statutory changes: Section 117 would have to be repealed; a definition of "computer program" would have to be imserted into $\S 101$; and a new $\S 117$, which would permit authorized users to adapt programs to their needs and to replicate the programs for archival purposes, was needed. Id. at 12. CONTU was of the opinion that the statutory redefinition of the term "copies" removed any doubt that machine-readable versions of programs were within the statutory reach of the Copyright Act. Under the 1976 Act "copies" had been defined to mean "material objects, other than phonorecords, in which a work is fixed by any inethod now known or later developed, and from which the work can be perceived, reproduced, or otherwise communicated, either directly or with the aid of a machine or device. The term 'copies' includes the material object, other than a phonorecord, in which the work is first fixed." 17 U.S.C. $\S 101$ (1982). Under the 1909 Act, the term "copy" had been interpreted to require liuman readability. See supra note 109; see also infra text accompanying note 194 for a contrary interpretation of the definition of "copy."

151. At the tine CONTU issued its final report, there had been three cases before the Supreme Court concerning the patentability of computer programs. Parker v. Flook, 437 U.S. 504 (1978) (program to update alarm limits for catalytic converter not patentable as a process); Dann v. Johnston, 425 U.S. 219 (1976) (program for cash dispensing machine not patentable because obvious); Gottschalk v. Benson, 409 U.S. 63 (1972) (program to convert bimary-coded numbers from one form to another held not to be patentable subject matter because it involved only mathematical formula). See infra text accompanying notes 430-36 for further discussion of Benson and Flook. Because in all three cases the Supreme Court had found the programs imeligible for patent protection, it was not clear the Supreme Court would ever find programs to be patentable. In none of these cases, however, had the Court gone so far as to say programs would never be eligible. See CONTU Final REPORT, supra note 1, at 16-17. 
were said to be too limited in scope to provide adequate protection. ${ }^{152}$ The CONTU majority report, however, nowhere suggests that any consideration whatever was given to developing a new form of intellectual property law to protect machine-readable programs. ${ }^{153}$

The sense of the mevitability of copyright as a proper form of protection contimued to build in the lengthy discussion of the compatibility of programs with copyright doctrine. Of course, the scope of the program copyright, in accordance with copyright tradition, would not extend to the ideas or processes, but only to the program author's "expression" of those ideas. ${ }^{154}$ Nor would Copyright protect the electroniechanical functioning of a machine. ${ }^{155}$ CONTU concluded that the use of programs in conjunction with machines was no more a copyright problent than was the use of phonograph records in conjunction with phonograph machines. ${ }^{156}$ The law would require that sufficient intellectual labor be put into a program to nrake it "an origmal work of authorship" within the meaning of the copyright law. ${ }^{157}$ If the idea of

Disadvantages of patent law, apart from the uncertamty, were said to be the expense and time required to obtaim legal protection, and the high standards required to achieve patent rights. CONTU FINAL REPORT, supra note 1 , at 17.

152. Trade secret law was said by CONTU to be "mappropriate for protectimg works that contain the secret and are designed to be widely distributed. Although this matters little in the case of unique programs prepared for large commercial customers, it substantially precludes the use of trade secrecy with respect to programs sold in multiple copies over the counter to small busimesses, schools, and consumers, and hobbyists." CONTU FINAL REPORT, supra note 1, at 17. The lack of national uniformity in trade secret law and the expense of maimtainimg secrecy were other factors which caused CONTU to conclude that trade secret protection was imadcquate. Id. at $17-18$.

Misappropriation theory, which was "based upon the principle that one may not appropriate a competitor's skill, expenditure and labor," id. at 18, was also subject to local variations in interpretation. CONTU felt this law, by itself, was unlikely to provide sufficient protection for programs. Id.

Table 1 in the CONTU Report shows the considerations CONTU weighed im deciding upon the most approprate form of legal protection. Of the theories it considered, CONTU reported that "copyright has the smallest negative impact." Id. at 18.

153. Commissioner Hersey's dissent suggests that other forns of protection for programs might develop if copyright did not. See Hersey Dissent, supra note 4, at 27.

154. CONTU FINAL REPORT, supra note 1, at 18-19. CONTU here discussed the "venerable case," Baker v. Selden, 101 U.S. 99 (1879); see infra notes 182-85 and accompanying text.

155. CONTU FINAL REPORT, supra note 1, at 20.

156. "All that copyright protection for programs, videotapes, and phonorecords ineans is that users may not take the works of others to operate their machimes. In each instance, one is always free to make the machine do the same thing as it would if it had the copyrighted work placed in it, but only by one's own creative effort rather than by piracy." Id. at 21 . But see infra notes 340-48 and accompanying text for a discussion of significant differences between computer programs and phonograph records.

157. CONTU FinAL REPORT, supra note 1, at 20. This labor is required by the Copyright Act of 1976, § 102, Pub. L. No. 94-553, 90 Stat. 2541, 2544-45 (codified as anended, at 17 U.S.C. \& 101 (1982) cited in CONTU Final REPORT, supra note 1, at 18. 
the program could be expressed in but a limited number of ways, the program embodying it could not be copyrighted. This too, CONTU said, was in accordance with copyright tradition. ${ }^{158}$

Near the end of its report about software protection, CONTU said that it would be best to leave to the courts the task of making fine distinctions as to the copyrightability of the "various manifestations" of programs. ${ }^{159}$ But the overall tenor of its report was that all programs were the same and none presented any copyrightability problems. ${ }^{160}$

\section{E. Inadequacies of the CONTU Final Report.}

The CONTU Final Report was misleading in a number of ways. First, CONTU interpreted the legislative history of the 1976 Act as unambiguously providing copyright protection for machine-readable programs when there was, in fact, ambiguity in the legislative history on the issue. ${ }^{161}$ CONTU's insistence that there was no ambiguity set the tone of the report, as if the presumption had already been estabhished solidly in favor of copyrightability.

Second, a serious failure in the CONTU Report was its refusal to address straightforwardly whether granting copyright protection to machine-readable programs was consistent with the constitutional goal of promoting the progress of science and the arts, which in patent and

158. CONTU FINAL REPORT, supra note 1, at 20. CONTU's investigation led it to conclude that program ideas could be expressed in a virtually limitless number of ways. Id. at $18 \mathrm{n} .106$. CONTU also discussed the means by which programs could be misappropriated. Why should it matter, CONTU asked, whether one copies from the handwritten form or duplicates a chip? Was not the same thing taken? Id, at 22.

159. "Should a line need to be drawn to exclude certain manifestations of programs from copyright, that line should be drawn on a case-by-case basis by the institution designed to make fine distinctions-the federal judiciary." CONTU FINAL REPORT, supra note 1, at 22. It is interesting that neither district court that found copyright protection for machine-readable versions of programs to be problematic relied on this statement to support its conclusion. See Data Cash Sys., Inc. v. JS\&A Group, Inc., 480 F. Supp. 1063, 1068 (N.D. Ill. 1979) affd on other grounds, 628 F.2d 1038 (7th Cir. 1980); see also Apple Computer, Inc. v. Franklin Computer Corp., 545 F. Supp. 812, 823-24 (E.D. Pa. 1982), rev'd, 714 F.2d 1240 (3d Cir. 1983).

160. CONTU also discussed the economic and cultural effects of extending copyright protection to computer programs. As to the former, CONTU believed there was no reason to fear that granting such copyright protection would have anticompetitive consequences. CONTU FINAL REPORT, supra note 1 , at 23-25. Even if it did, there were antitrust laws to deal with such problems. Id. As to the latter consideration, CONTU thought there was reason to be hopeful that granting copyright protection would result in widespread dissemination of programs, which in turn would result in many cultural advances-improved education, health care, and entertainment, to name a few. Any deluunanizing cffects that might be attributable to computers would be completely unrelated to the issue of the proper mode of protection for programs. Id. at 25-26. The Hersey Dissent and Nimmer Concurrence, supra notes 4-5, will be discussed at length infra notes 278-82, 337-48 \& 401-12 and accompanying text.

161. See supra note 132. 
copyright law has traditionally meant disclosure of the protected work. Third, CONTU was also misleading in its description of programs as "writings." 162 CONTU used the word "program" ambiguously, seldom telling the reader when it was referring to source code, when to Inachine code, and when to both. Solnetimes its statements about "programs" were true only for source code. ${ }^{163}$ CONTU repeatedly emphasized the "readability" of programs, when it knew or should have known that programs cease to be "readable" in any meaningful sense when converted to machine-readable form. 164 CONTU also emphasized the display functions of some computer programs-pictures, words, music -as if they were characteristic of all programs. ${ }^{165}$ In fact only a small fraction of programs produce any meaningful display. Moreover, what a copyright in a machine-readable program protects is something quite different than the visual display on a screen.

Fourth, the CONTU Report reflects a blindness to the "utilitarian" objection to the copyrightability of programs. There is a long tradition in copyright law of denymg copyright protection to "utilitarian" works, that is, works that have a usefulness other than the conveying of information or the displayimg of an appearance. ${ }^{166}$ Congress had codified and even stiffened this rule in 1976.167 CONTU's emphasis on the display functions of some programs as if they were representative of all programs contributed to the misunderstanding of the utility

162. See infra notes $265-68$ and accompanying text.

163. For example, CONTU stated that the set of instructions constituting a program "may be read, understood, and followed by a human being." CONTU FINAL RePORT, supra note 1, at 10. This is true for source code, but not for machine code. See supra note 74; see also infra notes 269 . 71 and accompanying text.

164. Id. The term "read" in the computer science lexicon has a precise technical ineaning very different froin the general public's view of the meaning of the word. See supra note 44. CONTU used "read" ambiguously, not differentiating between its use in the computer science sense and in its more ordinary sense. When one realizes that "load" or "retrieve" are synonyms for "read" in the computer-science sense, one can understand the implications of the machine aspect of the term. One may "load" a mousetrap or "retrieve" a book from the hibrary, but these are very different things froin reading a mousetrap or reading a book. See Hersey Dissent, supra note 4, at 30 ("[l]f a skilled programmer can 'read' a prograun in its mature, machine-readable form, it is only in the sense that a skilled home-apphance technician can 'read' the equally mechanical printed circuits of a television receiver."); Stern, The Case of the Purloined Object Code: Can It Be Solved? (Part 1), BYTE, Sept. 1982, at 420, 430 (critical of Tandy Corp. v. Personal Micro Computers, Inc., 524 F. Supp. 171, 173 (N.D. Cal. 1981), for unisunderstanding the term "read": "Worst of all, the court seems to have badly confused itself with its metaphors. The court speaks of a computer's 'reading' or 'understandimg' object code, and 'act[img] upon its instructions,' analogously to a person's reading or understanding a source program or other hiterary work. But the court mistakes its figure of speech for reahity. Computers and other unachines do not read books or understand them in the same sense as a person does.").

165. See infra notes 269,341 and accompanying text.

166. See infra notes 296-317 and accompanying text.

167. See infra notes 314-15 and accompanying text. 
issue. But many programs do not display or convey anything to humans; they are "utilitarian" in the copyright sense. Operating systems and microcode fall in this category, as do many application programs. Because CONTU failed to consider the copyright implications of these wholly utilitarian kinds of programs, the courts have been forced to grapple with the statutory contradiction. ${ }^{168}$ CONTU's misunderstanding of the utility issue also indicates a lack of understanding of the classical difference between patent and copyright protection for prograins. ${ }^{169}$

\section{Doctrinal Difficulties with Fitting Machine-Readable Programs into the Copyright Framework}

\section{A. The Failure of Machine-Readable Programs to Disclose the Ideas They Contain.}

A substantial part of the value of a commercially valuable piece of software once converted to inachine-readable form will be due to one or more new ideas embodied in that program. ${ }^{170}$ To inaximize profit potential, the programmer will want to publish the program in machine-readable form only, keeping secret the source code. If the source code is made public, the ideas in the innovative prograin can be used by competitors to develop a similar or even improved program which can be sold at a lower price. ${ }^{171}$

A computer program in machine-readable form is simply a bewildering string of thousands or millions of high and low voltage electrical impulses. Machine-readable programs reveal neither the ideas they embody, nor the manner in which the ideas are expressed. ${ }^{172}$ If copyright is permitted to extend to machine-readable prograins and there is no requirement that the source code be published, one of the traditional norms of copyright law would be subverted. It has been the rule that brimging new ideas into the public domain was the quid pro quo the public received in excliange for the limited monopoly right the au-

168. See infra notes $354-96$ and accompanying text.

169. See infra note 333 and accompanying text.

170. See infra note 419 and accompanying text.

171. See, e.g., Grogan, supra note 75, at 2:

[A]n understandimg of the logic and engineering of a program may assist a potential competitor in designing a similar system. The creation of solne programs may involve many man-months or man-years of development time, and allowing a competitor to understand fully the structure and the logic of such a program inay give the competitor what amounts to a 'free ride,' i.e., may allow the competitor to develop a similar product without devoting comparable time and resources to the developmental effort.

172. See supra note 74. The strongest evidence is that program vendors will often not sell the source code for the program, but only the machine-readable version. See supra note 75 . 
thor received to protect his or her expression of the ideas. ${ }^{173}$

As the law seems now to stand, the public may get for its grant of copyright monopoly to machine-readable computer programs a watch that accurately tells time according to the set of mstructions that the programmer gave the watch. The public will not, however, learn what specific instructions the watch contains or any innovative ideas the prograin employs to make the watch work properly. This raises two questions: Is this enough to satisfy the public interest? And is this enougl1 to satisfy the constitutional purpose underlying the law? The answer to both questions is no.

1. Disclosure as a Goal of Copyright Law. Disclosure as a goal of the copyright laws has constitutional underpinnings. Article I of the Uinted States Constitution empowers Congress to grant authors the exclusive right to their writings for a limited time "im order to promote the Progress of Science and the useful Arts." 174 As the Register of Copyright reported to Congress: "As reflected in the Constitution, the ultimate purpose of copyright legislation is to foster the growtl of learning and culture for the public welfare, and the grant of exclusive rights to authors for a limited time is a means to that end."175 Disclosure as a goal of copyriglit law was reaffirmed in 1975 by the Supreme

173. See, e.g., R. Saltman, supra ncte 123, at 2 (disclosure as quid pro quo for copyright protection).

174. U.S. ConsT. art. I, $\S 8$, cl. 8. In Graham v. John Deere Co., 383 U.S. 1 (1965), the Supreme Court considered the extent to which the constitutional clause concerning the promotion of science and the useful arts has been viewed as a limitation on the power of Congress to grant patents (and presumably also copyrights):

The Congress in the exercise of the patent power may not overreach the restraints imposed by the stated constitutional purpose. Nor may it enlarge the patent monopoly without regard to the innovation, advancement or social benefit gaimed thereby. Moreover, Congress may not authorize the issuance of patents whose effects are to remove existent knowledge from the public domain, or to restrict free access to materials already available. Innovation, advancement, and things which add to the sum of useful knowledge are inherent requisites in a patent system which by constitutional command must 'promote the Progress of . . . Useful Arts.' This is the standard expressed in the Constitution and it may not be ignored.

Id. at 5-6 (emphasis in the criginal).

175. Register of Copyrights, Report of the Register of Copyrights on the Gen. ERAL REVISION OF THE UNITEd STATES COPYRIGHT LAW 5 (1961). This report described the nature of copyright as follows:

In essence, copyright is the right of an auther to control the reproduction of his intellectual creation. As long as he keeps his work in his sole possession, the owncr's absolute control is physical fact. When he disclcses the work to others, however, he makes it possible for them to reproduce it. Copyright is a legal device to give him the right to control its reprcduction after it has been disclosed.

Copyright does not preclude others froin using the ideas or imformation revealed by the author's work. It pertains to the hterary, musical, graphic, or artistic form in which the author expresses intellectual concepts. It enables him to prevent others from reproducing his individual expression without his consent. But anyone is free to create his 
Court in Twentieth Century Music Corp. v. Aiken, ${ }^{176}$ where the Court declared that the immediate copyright aim of compensatimg authors for their creative efforts "must ultimately serve the cause of proinoting broad public availability" of the creative works. ${ }^{177}$ Both patent ${ }^{178}$ and copyright have been insistent on disclosure as an aim of the grant of monopoly.

The copyright protection an author receives is of a limited sort. The copyright protects agamst theft of the particularities of the author's expression, but not froin appropriation of any ideas expressed. ${ }^{179}$ The ideas in a work - even if they are highly origmal, extraordinarily ingenious, and exceedingly valuable, and even if they took the author unany years of effort to develop-have traditionally been viewed as beyond the scope of legal protection. ${ }^{180}$ The copyright does not protect the work that went into the creation, but only the words or notes or pictures the work reveals. The ideas are dedicated by the author to the public domain upon publication of the work.

The current copyright statute incorporates this principle. "In no case does copyright protection for an origmal work of authorship extend to any idea, procedure, process, system, method of operation, concept, principle, or discovery, regardless of the forn in which it is described, explained, illustrated, or embodied in such work."181 Although the principle was not codified in the copyright statute until

own expression of the same concepts, or to make practical use of them, as long as he does not copy the author's form of expression. Id. at 3 .

176. 422 U.S. 151 (1975). See also Hoehling v. University City Studios, Inc., 618 F.2d 972, 974 (2d Cir. 1980) ("The copyright provides a financial incentive to those who would add to the corpus of existing knowledge by creating origimal works."); J.L. Mott Iron Works v. Clow, 82 F. 316,318 19 (7th Cir. 1897) ("The object of [the copyright statute] was to promote the dissemination of learning."); Eichel v. Marcin, 241 F. 404, 410 (S.D.N.Y. 1913) ("Copyright protection is extended to authors, mainly with a view to inducing them to give their ideas to the public, so that . . . they may be used for the intellectual advancement of mankind."); infra notes 182-85 and accompanying text.

177. 422 U.S. at 156. See also Graham v. John Deere Co., 383 U.S. 1,9 (1965) for its discussion of Thomas Jefferson's philosophy on the nature and purpose of the patent monopoly (which stcins from the same constitutional provision as the copyright monopoly): "The patent monopoly was not designed to secure to the inventor his natural right in his discoveries. Rather, it was a reward, an inducement, to bring forth new knowledge. The grant of an exclusive right to an invention was the creation of society-at odds with the inherent free nature of disclosed ideasand was not to be freely given. Only imventions and discoveries which furthered human knowIedge, and were new and useful, justified the special inducement of a limited private monopoly."

178. See infra notes $240-54$ and accompanying text.

179. See, e.g., Sid \& Marty Krofft Television Prods., Inc. v. McDonald's Corp., 562 F.2d 1157, 1163 (9th Cir. 1977); 1 M. NIMMER, NiMMER ON CoPYRIGHT $\$ 1.10[B][2]$ (1982).

180. See, e.g., Synercoin Technology, Inc. v. University Computing Co., 462 F. Supp. 1003, 1014 (N.D. Tex. 1978).

181. 17 U.S.C. § 102(b) (1982). 
1976, it has been part of the copyright law tradition for a very long time.

The venerable case of Baker v. Selden ${ }^{182}$ illustrates this principle. Selden was the author of a copyrighted book on a novel way to do bookkeeping. The book contained an explanatory text and some sample ledger sheets. Baker's book on the same bookkeeping system imcluded very similar sample ledger sheets, albeit with somewhat different column headings and rearranged columns. Selden's heirs claimed infringement of the copyright. As the Supreme Court viewed the matter, there was no infringement of that which Selden's copyright protected. The evidence showed only that Baker had written on the same system of bookkeeping. Such similarities in expression as there were between Baker's and Selden's work were due to the similarity of their subject matter. The Court stated:

The copyright of a work on mathematical science cannot give to the author an exclusive right to the methods of operation which he propounds, or to the diagrams which he employs to explain them, so as to prevent an engineer from using them whenever occasion requires. The very object of publishing a book on science or the useful arts is to communicate to the world the useful knowledge which it contains. But this object would be frustrated if the knowledge could not be used without imcurring the guilt of piracy of the book. ${ }^{183}$

Selden's copyright entitled him to protection from usurpation of his "explanation" of the bookkeeping system; the "art" itself, unless patented, belonged to the public. ${ }^{184}$ The property right in the explanation-to the extent appropriation of it was necessary to practice the art-had to give way to the free right of the public to use the art. ${ }^{185}$

Two courts in recent computer program copyright cases have been so troubled by the lack of disclosure of the machine-readable programs that they have denied rehef on copyright claims, although they did so without reference to the Constitution. ${ }^{186}$ Courts in other computer program cases have either not addressed this issue ${ }^{187}$ or not been con-

182. 101 U.S. 99 (1879).

183. Id. at 103 (emphasis added).

184. Id. at 104.

185. The Court in Baker v. Selden also stated: "[T] methods of useful art have their final end in application and use; and this application and use are what the public derive from the publication of a book which teaches them." Id. at 104.

186. Data Cash Sys., Inc. v. JS\&A Group, Inc., 480 F. Supp. 1063, 1071 (N.D. 111. 1979), affd on other grounds, 628 F. 2d 1038 (7th Cir. 1980); see also Apple Computcr, lnc. v. Franklin Computer Corp., 545 F. Supp. 812, 823-25 (E.D. Pa. 1982), rev'd, 714 F.2d 1240 (3d Cir. 1983).

187. See, e.g., GCA Corp. v. Chance, 217 U.S.P.Q. 718 (N.D. Cal. 1982); Tandy Corp. v. Personal Micro Computers, Inc., 524 F. Supp. 171 (N.D. Cal. 1981). 
cerned by it. ${ }^{188}$ Several of these cases have involved operating systein programs. Although conceding the invisibility of operating system programs, the courts have generally refused to distinguish among types of programs for copyright purposes. ${ }^{189}$

A study published in 1977, the year before the CONTU Final Report was completed, concluded that copyright protection should not be

188. See, e.g., Apple Computer, Inc. v. Franklin Computer Corp., 714 F.2d 1240, 1247-48 (3d Cir. 1983) (holding that the copyright statute no longer requires communication with a human audience); Hubco Data Prods. Corp. v. Management Assistance, Inc., 2 Copyright L. Rep. (CCH) I 25,529 (D. Idaho Feb. 3, 1983) (drawing the same conclusion). There is little discussion of the issue in these cases.

Williams Elecs., Inc. v. Artic Int'l, Inc., 685 F.2d 870, 876-77 (3d Cir. 1982), a videogame case, also rejected a defendant's argument that to be copyrightable a work "must be intelligible to human beings and must be imtended as a medium of communication to human beings." The Williams court found the answer to this contention "im the words of the statute itself," $i d$. at 877 , in particular in the definition of the word "copy" in 17 U.S.C. $\$ 101$ (1982). For a contrary interpretation of the statute, see infra note 194 and accompanying text. Williams was relied on heavily by the Court of Appeals for the Third Circuit in its reversal of the district court's decision in favor of the defendant in Franklin Computer Corp., 714 F.2d at 1240. It is well to remember that Williams was a videogame case involving audiovisual and program copyrights that relied heavily on prior videogame cases which involved only copyrights on the audiovisual display of these games, not on the prograins responsible for producing the display. The audiovisual nature of the videoganes has allowed courts hearing challenges to the audiovisual copyrights to integrate this new form of work into traditional copyright docrine. See, e.g., Midway Mfg. Co. v. Artic Int'l, Inc., 547 F. Supp. 999, 1006 (N.D. Ill. 1982), aff'd, 704 F.2d 1009 (7th Cir. 1983) ("Plamtiff claims copyright protection only in the series of images and sounds appearing on the screen. . . . Specifically, the protection extends to the fanciful design of the characters used to play the games, the distimctive manner in which the characters inove, and the sounds associated with that movement."). See also Atari, Inc. v. North American Phillips Consumer Elecs. Corp., 672 F.2d 607, 610-13 (7th Cir. 1982) ("ocular comparison" of the two games inade); Stern Elecs., Inc. v. Kaufman, 669 F.2d 852, 855-56 (2d Cir. 1982); Midway Mfg. Co. v. Dirkschneider, 543 F. Supp. 466, 479-80 (D. Neb. 1981); Atari, Inc. v. Amusenent World, Inc., 547 F. Supp. 222, 226 (D. Md. 1981). But see Midway Mfg. Co. v. Strohon, 564 F. Supp. 741, 748, 753 (N.D. Ill. 1983) (no infringeinent of audiovisual copyright, but infringement of program copyright). The cour in Stern Electronics recognized that a particular videogaine audiovisual display may be produced by two completely different and independently developed programs. See 669 F.2d at 855 .

189. The district court in Apple Coinputer, Inc. v. Formula Int'l, Inc., 562 F. Supp. 775, 780 (C.D. Cal. 1983) (emphasis in origimal), affd, 725 F.2d 521 (9th Cir. 1984), rejected the argument that operating system programs should be treated differently than application programs:

Essentially, all computer programs as embodied in ROMs and diskettes are designed to operate a machine in such a way as to ultimately produce some useful communication to the user-that is their purpose. It is difficult to understand how they can be classified into two categories for copyright purposes, with protection afforded to one category and not the other, based on whether they directly generate that communication or whether they merely direct certain machine functions which eventually result in that expression ... . There is nothing in any of the statutory terms which suggest a different result for different types of computer programs based upon the function they serve within the machine.

While one could quarrel with the court's conclusion about the communicability of operating system prograins and blame CONTU for Congress's failure to make distinctions among programs based on their different functions, it is clear the court was right that the statute does not distinguish among programs as regards their display capabilities. 
extended to inachine-readable versions of programs as such, in large part because "copyright registration of object code as a computer program discloses almost nothing in return for the protection of the law." 190 The researchers argued that a grant of copyright protection to machine-readable programs was not only inconsistent with copyright tradition, but also against the public imterest. After pointing out that knowledge has become an increasingly important resource in the United States, the authors of the study stated:

[T]lere is a strong public interest in maximizing disclosure on two counts: first, for the inaximization of information transfer about original works, with all the implications for additional creativity that this implies; and second, to inake meaningful the exchange of full protection of copyright for disclosure through registration. If registration is to imply a minimal disclosure, then the proprietor is capable of obtaining two opposite types of protection, surely not the intent of Congress. A permission for minimal disclosure would give full copyright protection; but, would permit the proprietor to maintain his work essentially secret, particularly if he inakes it available through lease agreements only witl restrictive disclosure clauses. ${ }^{191}$

The problein is a new one. Until the advent of computer programs, copyrighted works that were sold to the public cominunicated the ideas they contained. Unpublished works that might have claimed copyriglt protection had little or no commercial value. Now it is possible both to publish a work and keep it secret, and keeping it secret is part of the way the commercial value of the work is mamtained. ${ }^{192}$ Computer programs in inachine-readable form are the first type of copyrightable work to have a major commercial value without disclosure. The well-known copyright scliolar Ralph S. Brown has expressed

190. R. SALTMAN, supra note 123 , at 62 . This study recommended allowing copyright protection for source code and treating machine-readable versions as "copies" of source code, but not treating inachine-rcadable forms as independently copyrightable. The Saltunan study was not discussed in the CONTU Final Report. Iskrant, an early student of the copyrightability of nnachinereadable programs, was also concerned about the compatibility of prograins with the copyright goal of disclosure. He thought the disclosure concerns could be resolved because the public could always go to the Copyright Office to look at the full text of the source code. Iskrant, supra note 30 , at 126. As indicated infra notes 211-22 and accompanying text, this is no longer possible. Iskrant also thought that a computer could be made to print out the source code, Iskrant, supra note 30 , at 106 , but this is possible only if the source code is separately stored in inemory, see supra note 67 .

191. R. SALTMAN, supra note 123 , at 52 .

192. See Note, Protection of Computer Software-A Hard Problem, 26 Drake L. REv. 180, 181 (1977). This Note expressed concern about the laek of disclosure of machine-readable programs. "Since the purpose of publishing copyrighted works is disclosure, it is not clear whether programs in [machine-readable form] could be 'published' since they were not imtelligible to the general public." Id at 195 . The Note went on to say that disclosure problems have becn solved by technology because programs could now be translated into printed fonn. Id. The Note was, however, in error on this point, as well as in beheving that prograininers would inake their prograins available to the public in a readable forn. 
his concern about this development by saying that "[t]he notion of secret copyrights is abominable." 193

Of course, neither the Constitution nor the federal copyright statutes, present or past, have exphcitly stated that disclosure is either a prerequisite to, or a goal of, federal copyright protection. ${ }^{194}$ But until the computer program problem arose, such an explicit statement had been unnecessary. Authors affixed copyright notices to their works when the works were published, 195 and publication meant that the work was disclosed to the public. ${ }^{196}$ While copyright law has respected

193. N. Y. Times, July 5,1983 , at 29 , col. 3 .

194. The text of $\S 102$ (a) of the Copyright Act of 1976, Pub. L. No. 94-553, 90 Stat. 2541 (codified, as amended, at 17 U.S.C. \& 102(a) (1982)), can be read to require disclosure of the copyrighted work. This provision states that copyright subsists "in original works of authorship fixed in any tangible medium of expression, now known or later developed, from which they can be perceived, reproduced, or otherwise communicated, either directly or with the aid of a machine." Id. 17 U.S.C. $§ 101$ (1982) defines "copies" to inean "material objects, other than phonorecords, in which a work is fixed by any method now known or later developed, and fronl which the work can be perceived, reproduced, or otherwise communicated, either directly or with the aid of a machine or device." Both sections seen to require that the work to be protected-in the case of computer programs, the set of statements or instructions-be communicated either directly or with the aid of a machine. Although both sections refer to the reproduction of the work, the words "otherwise communicated" indicate that Congress may have intended only reproductions of a communicative sort to be within the terms of the statute. The set of instructions that constitute a program cannot meaningfully be said to be communicated when the face of a silicon chip is viewed. Nor can it meaningfully be said that the instructions are communicated by aid of a machine, either directly or indirectly. Some programs in nuachine-readable form may cause soine words or pictures to be displayed on a screen, but those words or pictures are not the instructions which constitute the program. Furthermore, as supra notes 63-66 and accompanying text indicated, many programs do not have any display functions whatever but operate only within the computer.

There are some kinds of copyrighted works that are used in conjunction with a machine or device that do communicate the substance-the ideas and the expression-of the work that is protected. A tape recording, when played on a tape recorder, will communicate to the listener the whole of the copyrighted work, that is, the nuusic performed and recorded at a particular time and place by a particular person or group. The same is true of a videotape or a film. It is not, however, true of computer programs in machme-readable form, and that is why machine-readable programs may not be copyrightable under the statutory provisions. See Data Cash Sys., Inc. v. JS\&A Group, Inc., 480 F. Supp. 1063, 1066-67 \& n.4 (N.D. Ill. 1979), affd on other grounds, 628 F.2d 1038 (7th Cir. 1980); Stern, ROMs in Search of a Remedy: Can They Find It?? I CoMpUTER L. REP. 4, 6-7 (1982). Although the court in Data Cash Systems applied the 1909 Act to the copying of a computer chip for a chess game, it stated that it would have ruled no differently under the 1976 Act. The court thought ROM chips could not be "copies" of copyrighted works within the meaning of section 101 because the work in them could not be perceived with the aid of a machine or device. The 1976 Act "applie[d] to computer programs in their flow chart, source and assembly phases but not in their object phase." JS\&A, 480 F. Supp. at 1066-67 n.4.

195. Copyright Act of 1909, § 10, Pub. L. No. 60-349, 35 Stat. 1075, 1078 (repealed 1976); $c$. 17 U.S.C. \& 401 (1982) (analogous provision).

196. To obtain a federal copyright certificate, it was necessary to deposit a copy of the published work with the Copyright Office. Copyright Act of 1909, \& 11, Pub. L. No. 60-349, 35 Stat. 1075, 1078 (repealed 1976). 
the right of an author not to publisl his work, ${ }^{197}$ it has not previously liad to confront the dilemma of whetlier to protect published works unaccompanied by disclosure. The law has always assumed that, as the Supreme Court said in Baker v. Selden, "[t]lue very object of publishing a book on science or the useful arts is to communicate to the world the useful knowledge which it contams." 198

If the purpose of the copyright law were only to reward the creative efforts of an author, then rewarding the program autlior irrespective of the extent of his disclosure would be sensible. ${ }^{199}$ While rewarding the author is certainly an important purpose, it is not the only, nor even the major, purpose. The Register of Copyrights recently emphasized the importance of disclosure as a goal of copyright law, saymg "authorship, althougl often profoundly, even painfully, solitary, is fruitful and socially useful only when its works are disclosed."200 The constitutional purpose of promoting the progress of science and the arts will be furtleered only if copyright rewards solely those who make the progress known. Furthermore, seventy-five years is too long a period of protection to give program owners who do not disclose their works. ${ }^{201}$ The public is not getting enough in exclrange to warrant such

197. Federal copyright now subsists in original works of authorship froin the time they are first fixed in any tangible mediuun of expression. 17 U.S.C. $\$ 102(a)$ (1982).

198. 101 U.S. 99, 103 (1879).

199. One recent Note has concluded that "copyright law has evolved beyond its traditional purpose of enconraging disclosnre of original ideas." Note, Copyright Protection of Computer Program Object Code, 96 HARv. L. Rev. 1723, 1740 (1983). The Note acknowledged that disclosure had bcen an important goal of copyright from as early as $1834, i d$, and cited Twentieth Century Corp. v. Aiken, 422 U.S. 151 (1975), as affirming the continuation of this important historical goal, Note, supra, at 1739. The author based his conclusion that disclosure was no longer important on the "structure" of the Copyright Act of 1976. He pointed to nothing in the extensive legislative history of that Act or its subsequent amendınent to support the conclusion of congressional intent to make such a significant departnre from copyright tradition.

Another source which seems to accept the conclusion that disclosure is not required under the copyright law is National Conference of Bar Exauniners v. Multistate Legal Studies, Inc., 692 F.2d 478 (7th Cir. 1982), cert. denied, 104 S. Ct. 69 (1983). In a counterclaim to a copyright and trademark infringeinent complaint, the defendant challenged the constitutionality of the Copyright Office's "secure test" regulations, 37 C.F.R. $\$ 202.20$ (1984), under which the plaintiff's Multistate Bar Examination had been registered with the Copyright Office. The defendant argued that the regulations conflicted with the disclosure goals of the copyright law. The court of appeals affirned the district court's dismissal of this counterclaim, stating that "the statntory scheme of the Copyright Act demonstrates that the deposit provisions are not for the purpose of disclosure." Bar Examiners, 692 F.2d at 486. But educational and professional quahification tests would seem to present a special case. The public has a strong interest in the secnrity of these tests. See infra note 223. Very different considerations are involved in computer program nondisclosure.

200. Ladd, Donald C. Brace Memorial Lecture, New York University Law Center (Apr. 13, 1983), reported 25 PAT. Trademark \& Copyright J. (BNA) No. 627 (Apr. 28, 1983) 530, 533.

201. Corporate owners of published copyrighted works receive seventy-five years of protection under 17 U.S.C. $\$ 302$ (c) (1982). The Hersey Dissent questioned the desirability of granting such a lengthy duration of protection for computer programs. See Hersey Dissent, supra note 4, at 34. 
a lengthy monopoly.

2. The Code-Book Cases. Some proponents of the copyrightability of machine-readable programs have relied on a set of cases involving code books to demonstrate that human imtelligibilitythat is, disclosure of content to a human audience-is not necessary for a work to qualify for copyright protection. ${ }^{202}$ A close reading reveals that these cases do not, in fact, stand for the proposition that intelligibility is unnecessary for copyright. They stand only for the proposition that published code books are copyrightable. Except perhaps in recent computer program cases, the broader intelligibility issue does not seem to have been decided by the courts. ${ }^{203}$

The 1921 case of Reiss v. National Quotation Bureau, Inc. ${ }^{204}$ involved a challenge to the copyrightability of a published book entitled Simplex Pocket Blank Code. The book contamed a title page and a list of 6325 words, each of which was five letters in length, numbered consecutively froin 38,495 to 44,819 . The words liad apparently been coined for the first time by the author of the code book. The book was written to be sold to those who miglit wish to make use of it to construct a private code for sending cable messages. Parties could agree between themselves on the meaning they wislied to ascribe to one or more of the coined words in Reiss's book. Reiss's book simply provided readers with a set of otherwise meaningless words for these private communications.

The nature of the National Quotation Bureau's alleged infringement of the Reiss book is not apparent from the case, but it was most likely the same as that alleged in American Code Co. v. Bensinger ${ }^{205}$ and Hartfield $v$. Peterson, ${ }^{206}$ the other code-book cases, namely the subsequent publication of a competing code book making use of some substantial part or all of the first autlior's list of potential code words. ${ }^{207}$

202. The cases are Hartfield v. Peterson, 91 F.2d 998 (2d Cir. 1937); American Code Co. v. Bensinger, 282 F. 829 (2d Cir. 1922); Reiss v. National Quotation Bureau, Inc., 276 F. 717 (S.D.N.Y. 1921). Sources relying on one or more of these cases have imcluded Iskrant, supra note 30, at 117, and Note, supra note 199, at 1731. CONTU also found the code book cases useful to support its case for copyright protection for machine-readable code. See CONTU FINAL REPORT, supra note 1 , at 21 , infra notes $265-68$ and accompanying text.

203. See supra notes $186-88$ and accompanying text.

204. 276 F. 717 (S.D.N.Y. 1921).

205. 282 F. 829 (2d Cir. 1922).

206. 91 F.2d 998 (2d Cir. 1937).

207. In American Code, a preliminary mjunction had issued against the defendant's publication of a code book on the showing that the defendant had "appropriated everytling the plaintiff copyrighted, and ha[d] reproduced the same by photo-lithographic processes, and [was] proposing to sell it at a much cheaper rate than the plaintiff." 282 F. at 836 . In Hartfield, a final judgment 
Notwithstanding the eloquent inusings of Judge Learned Hand about whether words must have meaning to be copyrightable, ${ }^{208}$ it is clear that the author of the code book $\mathrm{m}$ Reiss had in fact disclosed what he intended to express. That is, he provided the reader with a set of words that could be used to send coded messages. The words themselves were not given a hidden coded meaning by the author. The value of the book lay im what it revealed. Because Reiss disclosed his ideas and his expression for a coding system, Reiss v. National Quotation Bureau is not a precedent upon which to build the arguinent that authors need not disclose their ineanings to get copyright protection for their works. ${ }^{209}$

against the author of a code book who had been found to have drawn a substantial proportion of its content from the plaintiff's code book was affirmed. 91 F.2d at 1001.

In Reiss v. National Quotation Bureau, Inc., 276 F. at 717, if the National Quotation Bureau had only sent someone a message using 100 words from Reiss's code book, it is be unlikely that National Quotation would have been found hable for infringement of the Reiss code book. Under Baker v. Selden, 101 U.S. 99 (1879), it would seem that such a use of Reiss's words would be necessary to practice the art the code book taught, and therefore, noninfringing. It would also seem that what National Quotation would have been expressing by such a use of Reiss's words was sufficiently different from what Reiss was expressing with the words as to be noninfringing. One might also argue that Reiss's publication of the coined words put them imto the public domain, and that since National Quotation was not publishing them in the saine order and to the sane end as Reiss, its use would be privileged.

208. The question whieh intrigued Judge Hand was whether the coined words already had to Lave a meaning to be copyrightable. He recognized that "[t]lese words have a prospective uneaning, but as yet they have not received it, like an einpty pitcher." Reiss, $276 \mathrm{~F}$. at 718 . He pointed out that soine writers had written avowedly senseless prose "designed by its sound alone to produce an emotion." Id. Furthennore, he said: "Works of plastic art need not be pictorial. They may be merely patterns, or designs, and yet they are within the statute. A pattern or an ornamental design depicts nothing; it merely pleases the eye. If such models or paintings are 'writings,' I can see no reason why words slrould not be sucl because they communicate nothing. They may lrave their uses for all that, aestlietic or practical." Id. at 718-19. All of Judge Hand's examples are of works with some commumicated content which made the works copyrightable.

209. For the code cases to be apposite to the problem that machine-readable programs present, it would be necessary for them to involve infringement claims based on coded messages of the sort illustrated by the following lypothetical. Assume A sends B a coded message which $C$ intercepts and through diligent effort decodes. Assume $A$ claims a copyright both in the coded message and in its uncoded version. Would C's publication of the decoded message infringe the copyright A claims in the coded message? The decoded message would contain none of the same words that the coded message revealed on its face. Yet there would be a one-to-one correspondence between the coded words and the expression for which they are meant to stand. Would C's publication of the decoded message infringe A's copyright in the uncoded version? Or would C's independent creation of this message mean $\mathrm{C}$ was free froin liability? If $\mathrm{C}$ discovered the exact expression $A$ was intending to convey to $B$, would C's publication be an infringing work? Does A's copyright extend to what he meant, to what he said, or botli?

Computer programs in machine-readable forn raise coded message problems. When one protects "11001100 1011101001010111 " by copyright, one may be proteeting the word "red," the number " 625,000 ," or the notes "C, F, A." The copyright owner of these digital expressions as part of a coinputer program is likely to want protection of both levels of meaning of his work, 
3. Copyright Office Policy on Disclosure of Computer Programs. In 1964, the Copyright Office decided to allow registration of computer programs, and to issue certificates of copyright for these works on condition that those who wished to register such works deposit a readable "copy"-in other words, the source code-of the program with the Office. ${ }^{210}$ After the enactment of the $1976 \mathrm{Act}$, the requirement that a copy of the full text of the source code be deposited with the Copyright Office was dropped. ${ }^{211}$ At present, the norm under the regulations is that the first and last twenty-five pages of the source code must be deposited with the Copyright Office. ${ }^{212}$ The deposit is intended to give the Copyright Office a basis for identifying the computer program as a copyrightable work written by the applymg author. The deposited source code on file with the Copyright Office under both present and past regulations is available for pubhe imspection. ${ }^{213}$

A deposit of only the first and last twenty-five pages of the source code does not make a meaningful public disclosure of the copyrighted object code. It is very easy for someone who wishes to disclose nothing about his source code to the Copyright Office to do just that. All that person must do is write fifty pages of "comments," twenty-five of which will be tacked on to the front and twenty-five to the end of the source code. $^{214}$ One company has an announced policy of deleting from the source code it deposits with the Copyright Office anything in it the company regards as "proprietary information." 215 Even if there is no

without having to tell anyone those meanings. The code-book cases do not help us to address this issue.

210. See Iskrant, supra note 30, at 100-02. The Copyright Office defined a readable copy as a "reproduction of the program in a form perceptible or capable of being made perceptible to the human eye." Id. at 101. There had been a controversy within the Copyright Office concerning whether prograin authors had to deposit copies which conveyed the content of the prograin in a way which was intelligible to hunans. In the end, it was decided that a copy of the source code would be required for registration. Id. at 101-02.

211. The present deposit regulations, see infra notes 212,217 \& 220, and accompanying text, were issued on September 19, 1978. See 43 Fed. Reg. 41,979 (1978). Computer programs have been exempted entirely froin the requirenent that copies of copyrighted works be deposited with the Copyright Office for transmittal to the Library of Congress on the ground that they are a type of work not needed for the Library's collection. See 17 U.S.C. $\$ 407(1)(c)$ (1982); 37 C.F.R. $\$ 202.19$ (c) (1984); Notice of Inquiry [Regarding] Deposit of Computer Programs and Other Works Containing Trade Secrets, 48 Fed. Reg. 22,951 (1983) [hereinafter cited as Notice of Inquiry]; see also 17 U.S.C. \& 408 (1982).

212. 37 C.F.R. $\$ 202.20$ (c)(vii) (1984). "[T]he Copyright Office has taken the position that the source code format of a computer program constitutes the best representation of the authorship in the prograin . . ." Notice of Inquiry, supra note 211, at 22,952. The text of the present regulation makes it clear that a "visually perceptible" copy must be produced. 37 C.F.R. $\$ 202.20$ (c)(vii) (1984).

213. See 37 C.F.R. $\$ \S 203.4,203.5$ (1984).

214. The author has heard programmers declare their intent to nnake such evasive deposits.

215. See N. Y. Times, July 5, 1983, at 29, col. 2. 
intentional evasion, the creative portions of a program are unlikely to be disclosed in the first twenty-five or last twenty-five pages of the source code. ${ }^{216}$ Because the Copyright Office is likely to be the only place-apart from the program autlior's safe-in whicli any portion of the source code is available, this means that the ideas in the source code effectively are withheld from the public.

An alternative is to deposit only a machine-readable version of the copyrighted program, ${ }^{217}$ but if the owner elects this option, the Copyright Office will not certify that "the object code format identifies an original work of authorship."218 This, of course, makes sense given that the Copyright Office cannot "read" the work, even to identify it. The Copyright Office allows this form of registration "for whatever it may be wortli based on an applicant's assertion that the object code identifies an original work of authorship."219 The claimant of the copyright will have to prove the work is an original work produced by the claimant.

There is also the possibility of obtaining special relief from the deposit requirement. This is available only in an exceptional case. ${ }^{220}$ If granted, alternative arrangements for deposit will be made. Many trade secret claimants have sought such special relief under the regulations. The Copyright Office is currently considering issuance of regulations that would allow computer programs to be deposited on a confidential basis. 221 On May 23, 1983, the Office issued a Notice of Inquiry whicl states: "Owners of copyright in works containing trade secrets, especially owners of copyright in computer programs, have expressed concern about public availability of materials deposited in the Copyright Office, and liave asked that the Office consider the possibility of special deposit provisions."222

216. The full text of a source code may amount to several thousand pages. The first 25 pages and the last 25 pages of source code are very likely to be "comments" which are not actually part of the program instructions. See supra note 76.

217. Notice of Inquiry, supra note 211, at 22,952.

218. Id.

219. Id.

220. 37 C.F.R. $\$ 202.20$ (d) (1984). The Copyright Office is somewhat more likely to grant relief "[w]here it is possible to excise the confidential material and deposit a substantial representation of the authorship in the works." Notice of Inquiry, supra note 211, at 22,952.

221. Notice of Inquiry, supra note 211 , at 22,952 .

222. Id at 22,951. Adoption of this regulation would mean that computer programmers would be altogether exempt from making any public disclosure of their works. The Office discussed some of the policy considerations favoring restricting public access to works containing matter claimed to contain trade secrets and requested public comment on several specific questions bearing on the issue. Id. at 22,952-54. As of June, 1984, the Copyright Office had received 43 comments concerning this Notice of Inquiry, and had not taken any further formal action on the proposed regulation. 
The tradition under copyright law has been to make the published works on deposit available to the public. ${ }^{223}$ While one of the purposes of requiring a deposit is to enable the Copyright Office to identify the work as to which the copyright certificate issues, historically this has not been the only reason for deposit.224 The symmetry of copyright and patent in terms of disclosure should be retained. If the notion of secret copyrights is indeed "abominable,"22s Congress should require adequate disclosure if the Copyright Office on its own initiative does not resume its proper role as the facilitator of disclosure.

4. Protecting Trade Secrets by Copyright. If disclosure is abandoned as a goal of copyright law, the federal law of copyright may soon become the primary ineans for the enforceinent of trade secret rights, at least insofar as the secrets may be embodied in some sort of "writing."226 The trend in this direction has already begun. Several plaimtiffs in recent computer program cases have sought and obtained relief both for copyright infringement and for trade secret misappropriation. 227 The proposed regulations to allow confidential deposits of copyrighted materials will reinove the last constraint which has thus far prevented the Copyright Office from being flooded witl documents contaming the nation's trade secrets. 228

How receptive the courts will be to copyright claims aimed at enforcing what are essentially trade secret rights remains to be seen. In a few instances, trade secret claims may be found to be preempted by the

223. See 17 U.S.C. $\$ \S 705-706$ (1982). The only prior exception to the rule of public availability has been for unmarketed educational tests sucli as those administered by the Educational Testing Service. See 37 C.F.R. $\$ 202.20$ (c)(vi) (1984). A legal challenge to the regulation permitting this exemption was defeated in National Conference of Bar Examiners v. Multistate Legal Studies, Inc., 692 F.2d 478 (7th $\mathrm{Cir}$. 1982). This exemption was granted upon a showing that inaking the tests "availab[le] for public inspection could 'severely prejudice the future utility, quality, and imtegrity of the materials.' " Notice of Inquiry, supra note 211, at 22,952.

224. The Library of Congress collection consists in large part of the works deposited by authors with the Copyright Office. See 17 U.S.C. $\$ 407$ (1982). The Copyright Office is now authorized by statute to exempt certain categories of work from the deposit requirement as to copies for the Library. 17 U.S.C. $\$ 407$ (c) (1982).

225. See supra note 193 and accompanying text.

226. The work containing the trade secret is required to be copyrightable subject matter under 17 U.S.C. \& 102(a) (1982). It may not need to be "written" in the sense of being a printed text or a drawing.

227. See, e.g., S\&H Computer Sys. v. SAS Inst., 568 F. Supp. 416 (M.D. Tenn. 1983) (denying summary judgment on copyright and trade secret claims); GCA Corp. v. Chance, 217 U.S.P.Q. 718 (N.D. Cal. 1982); see also Hubco Data Prods. Corp. v. Management Assistance Inc., 2 CopYRIGHT L. REP. (CCH) \25,529 (D. Idaho Feb. 3, 1983) (preliminary imjunction granted on copyright claims; trade secret claim not reached).

228. See supra notes 221-22 and accompanying text. 
copyright law, 229 but in most cases there may be soine basis for an allegation of a breached confidential relationship or other improper conduct on the part of the defendant, the additional presence of which would be sufficient to keep both claims alive. ${ }^{230}$ In a close case, a plaintiff, fearing federal law preemption, might clioose to bring only the copyright claim. But because one need not attach a copyright notice to trade secret inaterial-since it is unpublished ${ }^{231}$ - there would be nothing to prevent a plaintiff from delaying until shortly before drafting his complaint the decision as to which law he preferred to rely on. ${ }^{232}$

The advantages of copyright over trade secret actions are readily apparent: sure access to federal courts; ${ }^{233}$ ready availability of injunctive relief; ${ }^{234}$ recovery of attorneys' fees; ${ }^{235}$ and damages measured by the plaintiff's lost profits as well as the defendant's profits. ${ }^{236}$ If damages are difficult to prove, there are statutory dainages available. ${ }^{237}$ Thus, the likelihood of an ever-increasing number of essentially trade secret claims being litigated as copyright cases is strong.

Copyright has otler very significant advantages over trade secret law as a form of protection for secret materials. If, despite the owner's best efforts to inamtain the secret, it someliow leaks out, one can still get copyright protection for the "expression" of the trade secret, although not for the ideas. Once upon a time, one had to take a risk that, if inadequately safeguarded, both the ideas and the expression of a work containing a trade secret might fall into the public domain.

229. Only causes of action under state law that are equivalent to the exclusive rights of copyright are preempted by the federal copyright law. 17 U.S.C. $§ 301$ (a) (1982).

230. Trade secret law generally requires a showing of a breached confidential relationship or other improper conduct. See ResTATEMENT OF TORTS $§ 757$ (1939). This may prevent the cause of action from being equated with copyright claims. But see Luccarelli, The Supremacy of Federal Copyright Law Over State Trade Secret Law For Copyrightable Computer Programs Marked With a Copyright Notice, 3 Computer L.J. 19, $42-50$ (1981); Note, Protecting Trade Secrets Through Copyright, 1981 DUKE L. J. 981, 990-97.

231. A notice of copyright needs to be affixed only to published works. See 17 U.S.C. $\S \S 401-$ 402 (1982).

232. There might be a slight delay caused by obtaining a copyright registration certificate, which is a prerequisite to a copyright infringement suit. 17 U.S.C. $\$ 411$ (a) (1982). However, one has three years in which to file an action for copyright infringement, so this may not pose a serious impediment. 17 U.S.C. \& 507(b) (1982).

(1982).

234. 17 U.S.C. $\$ 502$ (1982). Infringing materials may also be impounded and destroyed under the copyright laws. 17 U.S.C. $\$ 503$ (1982). Willful infringers for commercial advantage may also be prosecuted for criminal copyright offenses. 17 U.S.C. $\$ 506$ (1982).

235. 17 U.S.C. $\& 505$ (1982).

236. 17 U.S.C. \& 504(a)(b) (1982).

237. 17 U.S.C. \& 504(c) (1982). 
Things, such as computer programs, that might have been considered trade secrets when under development, were forced to relinquish their status as trade secrets when sold in the inarketplace.238 With the aid of copyright and confidential deposit rules, trade secret owners would be able to maintain full protection over the secret and its expression for a seventy-five year period without any disclosure. It is not surprising, then, that software companies are pressing the Copyright Office for confidential deposit rules.

The legislative history of the 1976 Act does not reveal a clear congressional intent that the copyright laws be converted to the use of trade secret owners. ${ }^{239}$ It would be unwise for copyright law to displace the state law of trade secrecy, the sure result if the decision is made to abandon disclosure. Such a development would be an unwarranted bonanza for trade-secret owners at too high a cost to the public. It would transform copyright imto a general misappropriation law.

5. Protecting Patentable Ideas by Copyright. Copyright is not the only form of federal intellectual property law which has had disclosure of knowledge and ideas as one of its major aims. Patent law does not merely encourage disclosure; it requires disclosure. In order to obtam a patent, an inventor inust file a patent application ${ }^{240}$ that includes "a written description of the invention, and of the manner and process of making and using it, in such full, clear, concise, and exact terms as to enable any person skilled in the art to which it pertains . . . to make and use the same."241 The inventor is required to "set forth the best mode contemplated by the inventor of carrying out his invention," 242 and to furnish a drawing "where necessary for the understanding of the subject matter to be patented." 243 The Patent Office may also require the inventor to provide models, specimens, or ingredients of the invention before the patent will issue. 244

Failure to disclose the invention with sufficient specificity to enable skilled persons to inake it from that description will lead to a Pat-

238. See, e.g., Videotronics, Inc. v. Bend Elecs., Inc., 564 F. Supp. 1471 (D. Nev. 1983) (rejecting trade secret misappropriation claim because plaintiff failed to restrict access to the computer chips in its videogaine). The court stated: "Where such a computer program is made readily available to the public, . . . its conteuts may not be deenred a trade secret unless access to it is actually treated as a secret." Id. at 1476.

239. See generally Luccarelli, supra note 230.

240. 35 U.S.C. $\$ 111$ (1982).

241. 35 U.S.C. $\$ 112$ (1982).

242. Id.

243. 35 U.S.C. $\S \S 111,113$ (1982).

244. 35 U.S.C. $\$ 114$ (1982). 
ent Office decision not to issue a patent. ${ }^{245}$ If the failure to disclose goes undetected by the Patent Office and a patent issues, the patent can be challenged as invalid for failure to make adequate disclosure. ${ }^{246}$ Hiding the details concerning one's invention is considered a fraud on the Patent Office-as well as on the public - and can lead to antitrust liability. ${ }^{247}$ The patent application is confidential during the Patent Office's consideration, ${ }^{248}$ but if a patent issues, the patent application, imcluding the full description and drawings of the invention, will be available for inspection by the general public at the Patent Office. ${ }^{249} \mathrm{In}$ this way, disclosure to the public necessarily accompamies the issuance of the patent. 250

Patent law not only requires disclosure; it requires prompt disclosure. An inventor will be disqualified from obtaining a patent for his invention if he has not inade an application for a patent on it within one year of the coininencement of its use. ${ }^{251}$ As is the case where there has been an inadequately disclosed invention, a patent is subject to challenge in an infringement action if the inventor has failed to inake a prompt application for the patent. ${ }^{252}$ Proinpt disclosure has been required because of a fear that the inventor will try to prolong the period of his monopoly on the invention by holding back his patent apphication until someone else invented the same thing, or discovered how the

245. 35 U.S.C. $\S 131$ (1982). The Patent Office is required to make an examimation of the patent application and determine if the applicant is entitled to a patent. 35 U.S.C. § 131 (1982). An examination would necessarily reveal that an applicant had failed to disclose the invention as required by sections 111 and 112 . See 35 U.S.C. $\$ \S 111,112$ (1982).

246. 35 U.S.C. $\$ 282(4)$ (1982). See generally C. Hamburg, Patent Fraud \& 1Nequitable CONDUCT (1974).

247. See, e.g., Walker Process Equip., lnc. v. Food Mach. \& Chem. Corp., 382 U.S. 172 (1965) (sustaining monopolization charge under $\S 2$ of the Sherman Act based on misrepresentations about an invention to the Patent Office).

248. 35 U.S.C. \& 122 (1982).

249. See 35 U.S.C. $\S 153$ (1982); 37 C.F.R. $\S 1.11$ (a) (1984). Copies of these papers may be obtained made upon payment of a fee. 37 C.F.R. $\&$ 1.11(a) (1984).

250. There is one provision that allows certain inventions to be kept secret. See 35 U.S.C. $\$ 181$ (1982) (if the imvention is one in which the Government has a property interest and, in the opinion of the head of the interested government agency, disclosure would be detrimental to the national security, it can be withheld from public disclosure).

251. 35 U.S.C. \& 102(b) (1982). The one-year clock does not begin to run until the first public use of the invention, but courts have construed the "public use" phrase broadly. See, e.g., Egbert v. Lippmann, 104 U.S. 333, 337-38 (1881).

252. See, for example, Metallizing Eng'g Co. v. Kenyon Bearing \& Auto Parts Co., 153 F.2d 516, 520 (2d Cir. 1945), cert. denied, 328 U.S. 840 (1946):

[I]t is a condition upon an inventor's right to a patent that he shall not exploit his discovery competitively after it is ready for patenting; he must content himself with either secrecy, or legal monopoly. It is true that for the limited period of two years [under the patent statute then in effect] he was allowed to do so, possibly in order to give him time to prepare an application .... But if he goes beyond that period of probation, he forfeits his right regardless of how little the public may have learned about the invention. 
invention worked, and then asserting his priority over the other on the basis of being the first imventor. ${ }^{253}$ One court has said that "from the fiat of Congress . . . it is part of the consideration for a patent that the public shall as soon as possible begin to enjoy the disclosure."254

Of course, the inventor inay opt to keep his invention secret, and rely on trade secrecy law to protect it. ${ }^{255}$ If he is lucky, no one will invent the saine thing or be able to "reverse engineer" his product, and the security measures he adopts to keep the thing secret will not be breached; if so, his trade secret protection will be perpetual. But since these conditions will not always be met, trade secret law can be a risky sort of protection and one inappropriate to protect those inventions whose secrets can be discerned by examination of the product. ${ }^{256}$

To acquire the more secure protection of a patent, the inventor must be willing to disclose the secret that makes the invention work. Of course, inventors would, if given the choice, prefer to be able both to obtain a patent and to keep their inventions secret, but this the law will not allow. Disclosure of the secret is the quid pro quo the public gets in exchange for giving the imventor a seventeen-year patent monopoly on the invention. ${ }^{257}$ "[T] $[$ he very purpose of the patent system is to encourage disclosures." 258

253. Id. at 518 .

254. Id. at 520 .

255. See Kewanee Oil Co. v. Bicron Corp., 416 U.S. 470 (1974) (trade secret law not preempted by federal patent law).

256. See id. at $489-90$.

257. See, e.g., A. F. Stoddard \& Co. v. Dann, 564 F.2d 556, 563 (D.C. Cir. 1977); P. RoseNBerg, Patent Law Fundamentals $\S 1.02$ at $1-4$ (1982). See also Kewanee Oil Co. v. Bicron Corp., 416 U.S. 470, 480-81 (1974):

The stated objective of the Constitution in granting the power to Congress to legislate in the area of mtellectual property is to "promote the Progress of Science and useful Arts." The patent laws promote this progress by offering a right of exclusion for a limited period as an incentive to inventors to risk the often enormous costs in terms of time, research, and development. The productive effort thereby fostered will have a positive effect on society through the introduction of new products and processes of manufacture into the economy, and the emanations by way of increased einployment and better lives for our citizens. In return for the right of exclusion-this "reward for inventions," Universal Oil Co. v. Globe Co., 322 U.S. 471, 484 (1944) the patent laws impose upon the inventor a requirement of disclosure. To insure adequate and full disclosure so that upon the expiration of the 17-year period "the knowledge of the invention enures to the people, who are thus enabled without restriction to practice it and profit by its use," United States v. Dubilier Condenser Corp., 289 U.S. 178, 187 (1933), the patent laws require that the patent application shall include a full and clear description of the invention and "of the manner and process of making and using it" so that any person skilled in the art may make and use the invention. 35 U.S.C. $\$ 112$. When a patent is granted and the information contained in it is circulated to the general public and those especially skilled in the trade, such additions to the general store of knowledge are of such importance to the public weal that the Federal Government is willing to pay the high price of 17 years of exclusive use for its disclosure, which disclosure, it is assumed, will stimulate ideas and the eventual development of further significant advances in the art.

258. A.F. Stoddard \& Co. v. Dann, 564 F.2d 556, 563 (D.C. Cir. 1977). 
For copyright to cease to concern itself with disclosure would cause an unhealthy shift in the prevailing balance among the types of intellectual property law. There may be cases in which a computer programmer may have a choice whether to seek patent protection for the process his program embodies or a copyright for the particularities of its einbodiment. The choice would be seriously skewed in favor of copyright if copyright, but not patent, allowed the programmer to acquire a lengthy monopoly without any form of meaningful disclosure of the work. Copyright is already more advantageous by virtue of its lower standard of originality or creativity than patent, ${ }^{259}$ the greater ease and lesser expense and delay involved in getting a copyright registration certificate than in getting a patent, ${ }^{260}$ and its longer duration. ${ }^{261}$

Until now, federal copyriglit and patent law have both required disclosure. As the software industry perceives the copyright shift away froin requiring disclosure, programs for which patents might once have been sought will be copyrighted, and the information which they embody will be kept from the public.

6. CONTU on Disclosure. It is difficult to ascertam exactly what CONTU thought about disclosure of the ideas in computer programs, either as an aim of the copyright law or as a likely result of extending copyright protection to machine-readable programs. The Commission made no direct statement concerning either, although it inade statements that could be interpreted as expressing the view that extending copyright protection in this way would result in greater dissemimation of ideas and knowledge. There are, for example, a number of broad statements in the CONTU Final Report concerning the vast communicative possibilities computers and their programs open up for human beings, ${ }^{262}$ whicl1 although true are not directly related to the disclosure issue.

259. See, e.g., Alfred Bell \& Co. v. Catalda Fine Arts, Inc., 191 F.2d 99 (2d Cir. 1951).

260. Copyright registration fees are generally $\$ 10$ or less. See 17 U.S.C. $\$ 708$ (1982). The initial patent application fee is now $\$ 150$. There are also processing and issuance fees so that a patent applicant inay easily have to pay several lundreds, if not thousands, of dollars by the time the patent issues. There are also post-issuance fees. See 1 L. Horowitz, PATEnt Office Rules and Practice, Special Supplement 63-64 (1984). Copyright registration may be accomplished in a matter of weeks or months; the patent examination process may take several years.

261. The patent inonopoly is limited to 17 years. 35 U.S.C. $\& 154$ (1982). The copyright monopoly for an individnal author is life plns 50 years, and for a corporate owner, 75 years from the publication or 100 years from the creation of the work, whichever expires first. 17 U.S.C. $§ 302$ (1982).

262. See, for example, CONTU Final ReporT, supra note 1, at 9: "[T]hese machimes are opening up new avennes for recording, storing, and transmitting human thought. New means of communication transcend words fixed on paper or images on film and permit authors to commuricate creatively, adaptively, and dynamically with their audience." See also id. at 25-26 (cultural 
Clearly CONTU believed that copyright protection for machinereadable programs would mean that much more software would be dissemmated. Congress had directed the Commission to consider public access to copyrighted works as a factor in its deliberations about the computer-related copyright issues. ${ }^{263}$ The public access mandate was construed by CONTU as requiring consideration of whetler copyright would maximize the public availability of software products, but not as requiring consideration of whether copyright would maximize public access to the ideas, information, or knowledge contained in programs. ${ }^{264}$

CONTU found no problem with describing machine-readable programs as "writings" because of the "broad and dynamic meaning" of the constitutional tern "writing."265 If the meaningless comed code words in Reiss v. National Quotation Bureau, Inc.266 were copyrightable, why should machine code, which had meaning-albeit hiddennot be copyrightable? CONTU refers to programs as writimgs ${ }^{267}$ and elsewhere uses analogies to novels and drawings to illustrate how very similar computer programs are to other kinds of copyrightable works. ${ }^{268}$ At one point, CONTU seemed to presume that all programs produced displays of words, pictures, or sounds and that the displays

effects of granting copyright protection to programs which stress the potential enrichment of life, conmunication, and education). The possibilities, CONTU stated, were virtually limitless, "dependent only on the ingenuity employed in developing the programs that enable humans to cominunicate their ideas to one another through the intermediation of the nuachime and on the willingness of creators of such works to disseminate then at reasonable prices." Id. at 26 . CONTU argued that these positive contributions should be considered in determining whether copyright protection should be afforded to programs. The quality of the programs, however, should have nothing to do with the appropriateness of copyright as a form of protection.

263. See Pub. L. No. 93-573, § 201(c), 88 Stat. 1873, 1874 (1974); CONTU Final. Report, supra note 1, at 1. CONTU also recognized that the "ownership and control of information and the ineans of disseminating it are emerging as national and imternational policy issues. Concerns about the impact on individual freedom posed by the control of the flow of information are at the forefront of public debate." Id. at 3.

264. See, e.g., CONTU FINAL RePort, supra note 1, at 10-11. CONTU commissioned an econonic study of the likely effect on the public of extending copyright protection to programs; the study addressed the public access issue in terms of the availability of software products, not availability of the information in them. See 4 National Commission on New TeCHNOLOGICAL Uses of Copyrighted Works, Copyright, Congress and Technology: The Public ReCORD 112-226 (1980).

265. CONTU FINAL RePORT, supra note 1, at 14.

266. 276 F. 717 (S.D.N.Y. 1921), discussed supra notes 204-09 and acconipanying text.

267. See, e.g., CONTU FINAL REPORT, supra note 1, at 9, 11, 20.

268. CONTU stated that a program is created by putting symbols into a mediun: "In this respect, it is the same as a novel, poem, play, musical score, blueprint, advertisement, or telephone directory." Id. at 15. See also id. at 13 (comparing adaptations of programs to marginal notes in a book). At another point CONTU stated that videotapes, phonograph records, and coinputer programs were "capable of cominunicating with humans to a far greater extent than the coined code 
were the object of copyright protection. ${ }^{269}$ At numerous other points, CONTU stresses the human readability of prograins. ${ }^{270}$ The Commission appears to have mistaken the poimt at which a program ceases to be convertible imto human-readable form. The Commission's report suggests that not until the program is operating in the processing unit of the computer is the capability of human readability lost, ${ }^{271}$ when in fact it is lost as soon as the source code is converted to machine-readable form. CONTU may have been somewhat confused about the readability of prograins due to its misunderstanding of the technical meaning of "read" as used in connection with computers and programs. 272

The report's discussion on the trade secret law as a form of legal protection for machine-readable programs puts much emphasis on secrecy as one of that law's disadvantages froin a societal perspective. ${ }^{273}$

words discussed by Judge Hand in Reiss v. National Quotation Bureau." Id. at 21 (emphasis in original).

269. Id. at 21; see infra notes $340-41$ and accompanying text.

270. See, for example, CONTU FINAL REPORT, supra note 1, at 10: "The imstructions that make up a program may be read, understood and followed by a human being." "When other language is available, programmers are free to read copyrighted programs and use the ideas embodied in them in preparing their own works. This practice, of course, is impossible under a patent system, where the process itself is protected, and difficult under trade secrecy, where the text of a program is designed not to be revealed." Id. at 20 (emphasis im original). See also infra note 271 .

271. This misunderstanding is a critical one for the copyrightability issue. CONTU assumed that it was possible to produce a printed human-readable version of a program up until the point the program was in the ceutral processing unit of the computer. See CONTU FINAL REPORT, supra note 1, at 22. Machine-readable programs are not human-readable expressions. See note 74 supra. Although it is possible to cause a computer to print out the binary code that corresponds to the high and low voltages of the machine-readable program (called a "core dump"), this is still unreadable in any ineaningful sense. CONTU recognized that there was a point at which the machine-readable program ceased to be protected by copyright and became an uncopyrightable process. That was also the point at which the ability to produce a printed human-readable version of a prograin ceased. Put somewhat differently, in CONTU's view, the point at which the ability to produce a printed, human-readable version of a program ceased was the point at which copyright protection ceased. "When a program is copied into the ineinory of a computer, it still exists in a form fron which a human-readable version may be produced. . . . Only when the program is imserted-instruction by imstruction-into the processimg element of the computcr and electrical impuluses are sent through the circuitry of the processor to initiate work is the ability to copy lost. . . . If it should prove possible to tap off these impulses theu, perhaps, the process would be all that was appropriated and no infringement of the copyright would occur." CONTU FINAL REPORT, supra note 1, at 22 . It is, in fact, possible to tap off or "read" the electrical impulses in the central processing unit. See infra note 348 . So the distinction CONTU makes is one which makes no sense.

272. See supra note 164 .

273. See CONTU Final REPORT, supra note 1, at 17-18. 
Secrecy, CONTU noted, impeded the free flow of information. 274 Thus, time was wasted developing ideas which others had already developed but were keeping secret. ${ }^{275}$ It also meant higher prices because of the duphicated effort. 276 CONTU predicted a decline in the use of trade secret law if copyright protection were made available for machine-readable forms of programs. ${ }^{277}$ The implication a reader 1might well draw from these remarks is that CONTU thought copyright for computer programs in machine-readable form would mean less secrecy and a freer flow of information.

7. Hersey's Challenge. Commissioner Hersey questioned the majority's assumption that "copyright would ensure greater public access to innovative programs than would contmued reliance on trade secrecy law."278 Hersey's review of the evidence CONTU had collected indicated to him "that the industry would have no intention of giving up trade-secrecy protection in favor of copyright; to the contrary, every indication is that it would fight hard to assert its undeniable continuing right to the former."279 He noted it was obvious froin the copyright registration figures that the industry had opted for trade secrecy. 280

Hersey also pointed out that the Commission had been informed that the possibility of being forced to disclose programs under copyright law because of the threat of preemption of trade secrecy law would " 'driv[e] computer program owners into even deeper secrecy'by encryption, physical barriers to access, contractual restraints, nondisclosure agreements, and further innovative technical tricks for locking out pirates, thieves and coinpetitors. 'Secrecy will be seen as the only effective protection for their creations.' "281

274. "Since secrets are by definition known to only a few people, there is necessarily a reduced flow of informatiou in the marketplace, which hinders the ability of potential buyers to make comparisons and hence leads to higher prices." Id. at 17.

275. "Experts in the computer industry state that a further problein with respect to trade secrecy is that there is inuch human effort wasted when people do for themselves that which others have already done but are keeping secret." Id. at 17-18.

276. Id. at 17 , appendix $\mathrm{H}$ at 126 .

277. It did qualify this, however, by suggesting that any such decline would likely be attributable to the rapid increase in the number of widely distributed programs for which trade secret protection could not be successfully asserted. Id. at 18 .

278. Hersey Dissent, supra note 4, at 34.

279. Id.

280. Id. The sinall uunber of programs registered simce 1964, see supra note 114, suggested to Hersey that what registration had occurred was "in the nature of bet-hedging." Hersey Dissent, supra note 4 , at 34 . Id.

281. Hersey Dissent, supra note 4, at 34 (quoting from a response by Robert $O$. Nimtz of Bell Laboratories to a draft CONTU report). There is evidence that despite the extension of copyright 
Relaxation of the requirements for deposit of the source code of a program in order to receive a copyright certificate-changes CONTU was contemplatimg - would mean that "copyright itself would be used as one more device to prevent, rather than enable, access to innovative programs-one more device of industrial security."282 Hersey's comments indicate that CONTU had been made aware of the possibility that continued secrecy, rather than more disclosure, was the likely result of the extension of copyright protection to computer programs. CONTU simply chose to ignore it.

8. Disclosure and the Information-Rich Society. It is well to keep in mind that we are undergoing an Information Revolution. ${ }^{283}$ The authors of a recent book on computers currently under development in Japan and the United States have said:

The world is entering a new period. The wealth of nations, which depended upon land, labor, and capital during its agricultural and industrial phases—depended upon natural resources, the accumulation of money, and even upon weaponry-will come in the future to depend upon information, knowledge, and intelligence.

This is not to say that the traditional forms of wealth will be unimportant. Humans must eat, and they use up energy, and they like manufactured goods. But in the control of all these processes will reside a new form of power which will consist of facts, skills, codified experience, large amounts of easily obtained data, all accessible in fast powerful ways to anybody who wants it-scholar, manager, policymaker, professional, or ordinary citizen. And it will be for sale. 284

It may be worth adding that this knowledge-much of which will be embodied in computer programs im machine-readable form-may in the future be available only by sale. ${ }^{285}$ These same authors also state: "As everybody knows, knowledge is power. Machines that can amplify human knowledge will amplify every dimension of power."286

In the year 1984, cognizant of the dangers of information control brought so forcefully to our consciousness by George Orwell in his fa-

protection to programs, these contrivances to assure deeper secrecy are being used, and becoining inore attractive to those who do not yet use them. See supra note 107.

282. Hersey Dissent, supra note 4, at 34. Hcrsey also argued that the "entitlement of copyright protection to adaptations of programs might, under these circumstances, even further inhibit access, insofar as it provided owners with a covert means of protecting the underlying ideas of their program." Id. (einphasis in origimal).

283. See supra note 29 and accoinpanying text.

284. Feigenbaum, supra note 32, at 14 (emphasis in origimal).

285. See OTA Project Proposal, supra note 24 , at 13 , regarding its concerns about the effect on society as "information and knowledge are treated less and less as a free good and more and nore as a commodity to be bought and sold in the marketplace."

286. Feigenbaum, supra note 32 , at 8. 
mous book, it would seem a great folly to decide to abandon disclosure as a purpose of the copyright laws. Future generations would be the poorer for it, not simply by reason of the cost they will have to incur to acquire whatever knowledge might be for sale, but also by reason of the diminished public availability of knowledge which will necessarily follow.

\section{B. The "Utilitarian" Character of Machine-Readable Programs as a Copyright Problem.}

There is one very simple but important difference between a book which contains a set of instructions about how to do a particular task and a computer program in machine-readable form which contains a similar, if considerably more elaborate, set of imstructions on the same subject: The former informs a human being about how the task might be done; the latter does the task. ${ }^{287}$ Computer programs now operate traffic hight systems, update inventories, post sales, regulate pacemakers, tune radios, pump gas, and control car engines, among other tasks. ${ }^{288}$

It has long been copyright pohicy to deny copyright protection to utilitarian works. ${ }^{289}$ The designs of houses, typefaces, airplane wings, and teapots, once embodied in the item itself, have been considered outside the copyright realm. Repeated efforts have been made to amend the copyright statute to extend copyright or copyright-like protection to such works, but all have failed. ${ }^{290}$ Similarly, machines or machine parts have been excluded from copyright.291 The 1976 Act makes exphicit that if a work has "an imtrimsic utilitarian function that is not merely to portray the appearance of the article or to convey in-

287. See, e.g., Hersey Dissent, supra note 4, at 28: "Printed instructions explain how to do something; programs are able to do it." Programs, Hersey said, do not "describe or give instructions for the functions of the computer. They control [them]." Id. (emphasis in original). Of course, the source code, like a book, will tell the human how to do the task, but only the machinereadable version can do it.

288. See, e.g., Boraiko, supra note 32, at 421; Lueck, Automating Gas Stations, N. Y. Times, June 9,1983 , at 28 , col. 1.

289. See infra notes 296-312 and accoinpanying text.

290. See, e.g., Register of Copyrights, DRAFt, SECond Supplementary Report of the REGISTER OF COPYRIGHTS ON THE GENERAL REVISION OF THE U.S. COPYRIGHT LAW, chap. VII (1975) (reports that between 1914 and 1957 nearly 50 bills were introduced into Congress to extend copyright-type protection to designs of utilitarian objects, none of which passed botl houses of Congress) [heremafter cited as SECOND SuPPLEMENTARy REPORr]. (A design protection bill to extend copyright protection to origmal designs for useful articles (for a ten-year period) was recently introduced in Congress). See H.R. 2985, 90th Cong., 1st Sess. (1983). Even it would not grant protection insofar as the designs were dictated by utilitarian considerations.

291. See infra notes $335-36$ and accoinpanying text. 
formation," 292 it is not copyrightable. This statement recognizes that conveying information and portraying an appearance are a kind of utility, but not a kind of utility which will be objectionable in a copyright context. In copyright law "utilitarian" means havimg a utility other than conveying information or portraying an appearance of some kind.

When Congress decided in 1980 to extend copyright protection to computer programs, it neglected to consider the problents raised by the utilitarian nature of computer programs, ${ }^{293}$ because CONTU had misunderstood the issue. CONTU emphasized in its report the visual or auditory displays some programs produce as if these were representative of all programs, and it did not inform Congress of how integral to machine functioning and how utilitarian programs truly are. CONTU also stated baldly, although mcorrectly, that copyright protection had never been denied on utilitarian grounds. 294 CONTU's and the Congress's neglect has meant that the courts have been left to resolve a conflict between the provisions concerning utility and the provisions recognizing copyright protection for computer programs. Not surprisingly, courts have come to different conclusions about which provision is to be given precedence. 295

1. An Historical Perspective on the Utility Rule. Until the Supreme Court decision in Mazer v. Stein ${ }^{296}$ in 1954, it was not clear

292. 17 U.S.C. $\$ 101$ (1982) (definition of "useful article").

293. As indicated supra notes $9 \& 119-22$ and accompanying text, Congress paid little attention to computer program issues either in 1976 or in 1980.

294. CONTU failed to alert Congress to the utility problems posed by the copyrightabihity of computer programs. The following indicates the CONTU inajority's misunderstanding with respect to the utility issue:

[C]opyright practice past and present . . . recognizes copyright protection for a work of authorship regardless of the uses to which it may be put. The copyright status of the written rules for a game or a system for the operation of a machime is unaffected by the fact that those rules direct the actions of those who play the gaine or carry out the process. Nor has copyright been denied to works simply because of their utilitarian aspects.

CONTU FINAL REPORT, supra note 1, at 21 (emphasis added). As the remainder of the present section will inake clear, the emphasized statements in this passage are untrue. The statement with respect to the copyrightability of a systent for the operation of a machine is highly questionable, as indicated in the discussion of Baker v. Selden, 101 U.S. 99 (1879); see supra notes 182-85 and infra notes 383-87 and accoinpanying text.

295. Compare Data Cash Sys., Inc. v. JS\&A Group, Inc., 480 F. Supp. 1063 (N.D. Ill. 1979), affd on other grounds, 628 F.2d 1038 (7th Cir. 1980) (denying copyrightability of programs because of their inechamical functions) with Apple Computer, Inc. v. Formula Int'l, Inc., $562 \mathrm{~F}$. Supp. 775 (C.D. Cal. 1983), aff d, 725 F.2d 521 (9th Cir. 1984) (rejecting utility objection to copyrightability of programs). Compare also the district court decision in Apple Computer, Inc. v. Franklin Computer Corp., 545 F. Supp. 812 (E.D. Pa. 1982), rev'd, 714 F.2d 1240 (3d Cir. 1983) (denying preliminary injunction in part because of the utilitarian character of computer programs at issue) with the court of appeals's decision, 714 F.2d 1240 (3d Cir. 1983); see also infra notes 35487 aud accompanying text.

296. 347 U.S. 201 (1954). 
whether copyright was available to provide federal statutory protection for the design of any part of a utilitarian work. ${ }^{297}$ Mazer $v$. Stein began the process of clarifying the very limited circumstances under which some features of a utilitarian object-not the utilitarian object itselfcould be copyrighted.

Mazer and Stein were both lamp manufacturers. Stein coinplained that Mazer's lamps infringed a copyright Stein held in a statuette that both manufacturers used as bases for certain of their respective lainps. ${ }^{298}$ Stein conceded that he had copyrighted the statuette intending to use it as a lamp base. Among the arguments Mazer raised to defeat the copyright claim was that Stein's lamp was excluded from copyright protection because it was a utilitarian object, not a work of art as the statute required. The Supreine Court rejected Mazer's argument, holdimg that the fact that the statuette had been incorporated into a lamp design did not in and of itself deprive the statuette of copyright protection.299 The Court noted that the Copyright Office had, over the years, permitted registration of various works of art that had some utilitarian aspects. ${ }^{300}$ The Court voiced approval of the Copyright Office regulation which provided that the Office would issue registration certificates for "works of artistic craftsmanship, in so far as their form but not their mechanical or utilitarian aspects are concerned, such as artistic jewelry, enamels, glassware, and tapestries, as well as all works belonging to the fine arts, such as paintings, drawings, and sculpture."301 Because the copyright statute did not require that the "work of art" be a "work of fine art,"302 the Court thought the statuette was copyrightable. It was the art in the statuette that the copyright protected. ${ }^{303}$ The sub-

297. See, e.g., Fabrica, Inc. v. El Dorado Corp., 217 U.S.P.Q. 698 (9th Cir. 1983) (indicating that prior to Mazer, utilitarian objects were assumed to be entitled to no copyright protection); SECOND SUPPLEMENTARY REPORT, supra note 290 , at 4, which reported that it was widely assumed that only design patent protection was appropriate. For various reasons, described id. at 413, the design patent statute was regarded as an ineffective ineans of legal protection for designs.

298. Stein liad also sold some of the copyrighted statuettes as statuettes. However, only an imsignificant portion of the income from Stein's sales was due to sales of the statuettes alone. Mazer, 347 U.S. at 203.

299. Id. at 214-15.

300. Id. at $212 \&$ n. 25.

301. Id. at 212-13 (quoting 37 C.F.R. $\$ 202.8$ (1949)) (emplasis added).

302. The Suprene Court in Mazer regarded as particularly significant the Congress' decision to delete the "fine arts" clause of the 1870 Copyright Act (which included as copyrightable subject matter any "statue, statuary, and . . . models or designs imtended to be perfected as works of the fine arts"), Copyright Act of 1870, ch. 230, \& 82, 16 Stat. 198, 212 (1870), when enacting a new copyright statute in 1909 which referred only to "works of art," Copyright Act of 1909, ch. 320, § 5, 35 Stat. 1075, 1076-77. See Mazer, 347 U.S. at 213-14.

303. "The dichotomy of protection for the aesthetic is not beauty and utility but art for the copyright and the invention of original and ornamental design for design patents." Mazer, 347 U.S. at 218 . 
sequent embodiment of the statuette in a lamp did not deprive the statuette of its status as art.

After Mazer, the Copyright Office issued additional regulations to clarify its position about the copyrightability of works with utilitarian features. This regulation established the test that, until the 1976 Act became effective, was used in all cases challenging copyrights on utility grounds. It stated:

If the sole intrinsic function of an article is its utility, the fact that the article is unique and attractively shaped will not qualify it as a work of art. However, if the shape of a utilitarian article incorporates features, such as artistic sculpture, carving or pictorial representation, which can be identified separately and are capable of existing independently as a work of art, such features will be eligible for registration. ${ }^{304}$

This regulation requires two inquiries: (1) whether the sole intrinsic function of a work is utilitarian, and (2) whether the feature for which copyright protection is sought is capable of existing independent of the functional aspects of the work. Onc treatise author has statcd that "[p]hysical separability would presumably mean that after removal of those features which are necessary for the utilitarian function of the article, the artistic features would remain intact."30s

The lamp in Mazer had a number of functional aspects-includimg the wiring, the lainp apparatus, and the shade. The lainp required a base, but the lamp functioned as a lamp no better or worse for having a statuette-rather than some equally tall and broad form, such as a milk carton-as its base. The lamp was not solely "utilitarian." It had at least one nonfunctional aspect, namely the statuette as its base. That the statuette was capable of existing independently froin the lamp was evidenced by the fact that it had been copyrighted separately from the lamp. Soine statuettes were sold as statuettes, not as lamp bases. $M a$ zer also makes clear, however, that the copyrightability of the statuette did not inean copyright protection could be obtained for any other aspect of the lainp.

Among the inany things that have been found not to be copyrightable because of their utilitarian character are an attractive "high tech" design for an outdoor lighting fixture, ${ }^{306}$ wire-spoked wheel covers for

304. 37 C.F.R. $\S 202.10$ (c) (1976) (emphasis added).

305. 1 Nimmer ON COPYRIGHT, supra note $179, \S 2.08[B][3]$ at 2-96.

306. Esquire, Inc. v. Ringer, 591 F.2d 796 (D.C. Cir. 1978) (suit against the Register of Copyrights for refusing to accept the application for copyright registration for the lighting fixture because of the inseparability of utihtarian and other aspects of the work). 
automobiles, ${ }^{307}$ carpet display folders, ${ }^{308}$ typeface designs, ${ }^{309}$ artistically designed watch faces, ${ }^{310}$ and a sculpted design of curved lines, ridges, and troughs for shoe soles. ${ }^{311}$ While architectural or engmeering plans may be copyrightable, it is generally accepted that a structure built from those plans, unless a monument or some other completely nonfunctional work-however "fixed" and "original" it unight becannot be a "copy" of those plans within the meaning of the copyright laws. ${ }^{312}$

In revising the copyright law in 1976, Congress strengthened the rule against granting copyright protection to utilitarian features of a work. The copyright regulations in effect prior to the revision had provided that a work would not be copyrightable if "the sole intrinsic

307. Norris Indus., Inc. v. International Tel. \& Tel. Corp., 696 F.2d 918 (1 Ith Cir. 1983) (invalidating registered copyright for wire wheel covers; Register of Copyright joined IT\&T in contesting the validity of the registration certificate previously issued in reliance on the district court decision in Esquire, Inc. v. Ringer, 414 F. Supp. 939 (D.D.C. 1976), which was reversed two years later by the Court of Appeals for the District of Columbia, see supra note 306; because the covers protected lugnuts, brakes, wheels and axles from dainage and corrosion, they were utilitarian and not copyrightable).

308. Fabrica, Inc. v. El Dorado Corp., 217 U.S.P.Q. 698 (9th Cir. 1983) (display folder containing carpet samples accompanied by description of carpet's technical specifications, said by both parties to be superior in structure and appearance to previous types of carpet display folders, held utilitarian and hence uncopyrightable). "The folders' usefulness in marketing is their only reason for existence." Id. at 700 .

309. Eltra Corp. v. Ringer, 579 F.2d 294 (4th Cir. 1978) (affirming dismissal of mandanus action against Register of Copyright to accept registration of typeface design). See also Leonard Storch Enters. v. Mergenthaler Limotype Co., 208 U.S.P.Q. 58 (E.D.N.Y. 1980) (dismissing unfair competition and misappropriation claims arising out of use of uncopyrightable typeface design on grounds that Congress' decision not to allow copyright protection for typeface designs meant typeface design was in the public doinain).

310. Vacheron \& Constantim-Le Coultre Watches, Inc. v. Benrus Watch Co., 260 F.2d 637 (2d Cir. 1958).

311. SCOA Indus. v. Famolare, Inc., 192 U.S.P.Q. 216 (S.D.N.Y. 1976).

312. See, for exanuple, Katz, Copyright Protection for Architectural Plans, Drawings, and Designs, 19 LaW \& CONTEMP. Prons. 224, 236 (1954) (emphasis in original; footnote omitted): “An architectural plan is a technical writing. It is capable of being copied only by similar technical writings, that is, by other plans, etc. A structure is the result of plans, not a copy of them." See also Nucor Corp. v. Teunessee Forging Steel Serv., 476 F.2d 386, 391 (8th Cir. 1973); HousE REPORT, supra note 120, at 55 ("An architect's plans and drawings would, of course, be protected by copyright, but the extent to which that protection would extend to the structure depicted would depend on the circuunstances. Purely nonfunctional or monumental structures would be subject to full copyright protection under the bill, and the same would be true of artistic sculpture or decorative ornamentation or einbellishment added to a structure. On the other hand, where the only elements of shape in an architectural design are conceptually inseparable from the utilitarian aspects of the structure, copyright protection for the design would not be available."); Russell v. Trimfit, 428 F. Supp. 91 (E.D. Pa. 1977), affd, 568 F.2d 770 (3d Cir. 1978) (copyright in drawing of stocking not infringed by manufacture of competing stocking); Muller v. Triborough Bridge Auth., 43 F. Supp. 298 (S.D.N.Y. 1942) (copyright in drawing showing a novel bridge approach design did not give copyright protection to that bridge design; Triborough Bridge not an infringement of the copyrighted drawing even if deliberate use of the idea). 
function" of the work was its utility. ${ }^{313}$ The new Act provided that the work would not be copyrightable if it had "an intrinsic utilitarian function that is not merely to portray the appearance of the article or to convey information." 314 The change from "sole" to "an" was significant and intentional. ${ }^{315}$ The statutory definition also clarified the test for distinguishing what was utilitiaran froin what was not. Any function beyond the portrayal of an appearance or conveyance of information is "utilitarian," and places the work beyond the protection of copyright. Contrary to CONTU's conclusions, the originality of a work is not the sole legitimate copyright criterion. ${ }^{316}$ Congress intended that works be denied copyright protection on account of their utility, ${ }^{317}$ as had been true for decades.

\section{Why Copyright Protection Does Not Extend to Utilitarian} Works. The reasons why copyright law should not extend to utilitarian works inay not be immediately apparent, but a rich variety of those reasons exists. Understanding the complex rationale behind this rule will aid in understanding why coinputer programs raise similar utilitarian problems.

First, there may be constitutional problems with extending copy-

313. See supra note 304 and accompanying text.

314. 17 U.S.C. $\$ 101$ (1982) (definition of "useful article"). The utihtarian issue is sometimes posed as one of differentiating between "apphed art," which is copyrightable, and "industrial design," which is not. Clarifying what was meant by "industrial design," the House Report on the 1976 Act stated: "[A]lthough the shape of an industrial product inay be aesthetically satisfying and valuable, the Committee's intention is not to offer it copyright protection under the bill. Unless the shape of an automobile, airplane, ladies' dress, food processor, television set, or any other industrial product contains some element that physically or conceptually, can be identified as separable from the utihtarian aspects of that article, the design would not be copyrighted under the bill." House RePORT, supra note 120, at 55. The test of separability does not depend on the intent of the designer: "[E]ven if the appearance of an article is determmed by esthetic (as opposed to functional) considerations, only elements if any, which can be identified separately from the useful article as such are copyrightable. And even if the three-dimensional design contains some such element (for example a carving on the back of a chair or a floral rehef design on silver flatware), copyright protection would extend only to that element, and would not cover the overall configuration of the utilitarian article as such." Id.

315. See, for example, Fabrica, Inc. v. El Dorado Corp., 217 U.S.P.Q. 698, 700 (9th Cir. 1983) (emphasis in origmal): "The significant change from the prior law is that the courts need no longer determine whether an article's function is solely utilitarian. Now, if an article has any intrinsic utilitarian function, it can be denied copyright protection except to the extent that its artistic features can be identified separately and are capable of existing independently as a work of art."

316. CONTU stated at one point in its report that the "only legitimate question regarding copyrightability is: Is the object an original work of authorship?" CONTU FINAL REPORT, supra note 1, at 25. See also supra note 294.

317. See supra note 314. 
right protection to "utilitarian" works. ${ }^{318}$ Congress is empowered under the Constitution to give "authors" a limited term of protection for their "writings" in order to promote the progress of science and the arts. 319 While it is true that the term "writmgs" has been construed broadly enough to include such things as photographs, which are not "writings" in a technical sense, ${ }^{320}$ an extension of protection to photographs is not constitutionally problematic. If a drawing of an object can be a "writimg," and if an etching of the same object can be a "writing," a photograph of the same object should be considered a "writing." "321 All three portray an appearance of an object. It is possible that all three may also convey information. Therem hes their value, and whatever utility they possess. Somewhat more constitutionally problematic is whether a sound recording can be considered a "writing." Written notations of music are clearly "writimgs." Sound recordmgs are only a different way of "recording" the music.322 Although sound recordings do not produce visible display, they do produce an audible "display." In this hes their utility and their value. The rationale for treating both forms of music as "writings" thus seems the same, and is consistent with the constitutional purpose.

It is quite another thing to say that a house-or a TV set or an airplane wimg or a machine-readable program-is a "writing" in the constitutional sense. A house may be constructed in accordance with the directions set forth im a set of architectural plans, yet to say the house is copyrightable because the architeetural plans are copyrightable is problematic. For if a house is a "writmg," what man-made things would not be? Although a house, like the drawing, might be said to portray an appearance, it does more than that. The value of the house lies more in what it does than in how it looks, just as the value of a machine-readable program lies more in what it does than im what it or the source code might convey to a human audience. The clearest way to make a distinction between things that can be "writmgs" in a constitutional sense and things that cannot be is to inquire whether they do more than portray appearances-visible or audible-or convey information. If they do, they are, pro tanto, not "writings."

318. See, e.g., Nimmer Concurrence, supra note 5, at 26.

319. U.S. Const. art. I, $\S 8$, cl. 8.

320. See, e.g., Burrow-Giles Lithographic Co. v. Sarony, 111 U.S. 53, 58 (1884) (rejecting arguinent that a photograph could not be protected by copyright because not a "writing").

321. The same should be true of a digital encoding of a visual image of the saine object.

322. That sound recordings have become the major form of distributing music may also figure in the analysis. When the Founding Fathers wrote the Constitution, written texts were the primary means of distributing musical works. 
Another reason to treat architectural plans differently for copyright purposes from the structure made from them is that the structure "expresses" a different set of things than the plans do. The plans convey information of a sort that the structure alone does not. Much of the detailed information (as well as many of the ideas) expressed in the plans will not be apparent from an examination of the structure. The external face of the structure tells little of what went into constructing it, which is the substance of the plans. ${ }^{323}$ One might be able to infer some things about the plans from the external face, but one could not reconstruct the plans, except by tearing the structure apart, and even then soine features of the plans might not be detectable. One might as well draft a different set of plans-which would, of course, be noninfrimging - to construct a building of the same appearance. ${ }^{324}$

Furthermore, while the design of a building may have considerable aesthetic appeal, there nay be good reasons not to permit the architect from whose plans it was constructed to have a copyright monopoly on structures of that form. An architect may have chosen a particular design for the lintel over the front door of a structure, partly because of the attractiveness of the shape and partly because that particular lintel will prevent some other part of the house from falling on those who enter the structure through the door. To give the designer of that lintel a copyright on it would mean that other architects could not use it without the former's permission. If that design is not only the most visually appealing but also the safest way to construct that door frame, it would be socially undesirable to permit the existence of a copyright in it to impede use of a safe design. Allowing a copyright on the frivolous embellishinents of the structure-a particular colorful design in the floor tiles, for example-is less problematic, for there are many variations possible for floor tiles. The next hacienda will be none the less safe for the first one's having a copyrighted design in the floor tile pattern.

Another concern may be the duration of copyright. Seventy-five years of exclusive right may be too long a tern to satisfy the public interest as to utilitarian works. It would be one thing to grant seventyfive years of exclusive protection to a floor tile pattern and quite another to grant the same period of exclusive rights to lintel designs. The

323. It is, of course, not the information in the plans, as such, that the copyright protects. One cannot, for example, acquire copyright protection for using bricks to make an outhouse by drawing up architectural plans which direct the use of bricks.

324. The same issue arises with respect to computer programs. An identical audiovisual display can be produced by two different and noninfringing computer programs. See Stern Elecs., Inc. v. Kaufman, 669 F.2d 852 (2d Cir. 1982). 
public has a strong interest in having either unrestricted access to useful works, or at least a relatively short term of restricted access to them..$^{325}$ This public interest, as much as the more extensive inonopoly right, is what accounts for the considerably shorter term for patent riglits. ${ }^{326}$

There is yet another important concern. If one eliminates the rule against copyright protection for utilitarian works, one eliminates the clearest basis for distinguishing between copyright and patent law. The law has generally not sought to discourage people froin copying functional designs of objects unless the functional aspect was inventive enough for a patent to issue on it. There is at present only one area in which patent and copyright overlap: ornainental designs for articles of manufacture. ${ }^{327}$ One who invents a "new, original and ornamental design for an article of manufacture" may protect it by design patent ${ }^{328}$ or by copyright, assuming the separability test can met. ${ }^{329}$ Design patents, like copyrights, are not available to protect designs which are dictated solely by considerations of function. ${ }^{330}$ To protect functional designs one needs a patent of another sort. ${ }^{331}$ While Congress undoubtedly has the power to permit some overlap of subject matters, the copyright and patent realms have generally been kept separate by the requireinent that a thing have utility to be patentable ${ }^{332}$ and not have utility to be copyrightable. ${ }^{333}$

325. Recognition of this policy may be part of the reason the chip design protection bill, see infra note 350 , is intended to be limited in its term of protection to ten years.

326. See generally White, Why a Seventeen-Year Patent?, 38 J. PAT. OFF. Soc'Y 839 (1956).

327. See, e.g., Mazer v. Stem, 347 U.S. 201 (1954); In re Yardley, 493 F.2d 1389 (C.C.P.A. 1974).

328. 35 U.S.C. $\S 171$ (1982). The design patent statute does not require the design to be useful. 1 S. Chisum, ChIsum on Patents § $1.04[1]$ at 1-117 (1983). Design patents are shorter in duration than either copyright or regular patents; they may be granted for three years and six months, for seven years, or for fourteen years, as the applicant elects. 35 U.S.C. $\$ 173$ (1982).

329. See 1 ChISUM ON PATENTs, supra note 328, § 1.04[5]; supra notes 304-05 \& 314-15 and accompanying text (regarding the separability test).

330. 1 ChISUM ON PATENTS, supra note 328, § 1.04[2] at 1-117.

331. See id. $\S 1.04[2]$ at $1-125$.

332. 35 U.S.C. $\$ 101$ (1982). Microcode has been held to be patentable as a part of hardware in In re Bradley, 600 F.2d 807, 812 (C.C.P.A. 1979), affd by an equally divided court sub nom. Diamond v. Bradley, 450 U.S. 381 (1981). If microcode las sufficient utility to be patented, it is questionable whether it can liave the nonutility to be copyrightable.

333. See supra notes $289-92$ and accompanying text. How exclusive copyright and patent laws are or should be has not been much litigated. There was some discussion of the issue im Mazer v. Stein, 347 U.S. 201 (1954), discussed supra notes 296-303 and accompanying text. The defendant Mazer argued, among other things, that if any federal monopoly was to be given to the lamp design at issue in that case, it had to be a design patent, not a copyright. Mazer argued that Congress had intended to grant protection only to those designs that met the standard of creativity demanded by the patent statute and that permitting an overlap of copyright and patent would be unwise. The Supreme Court rejected Mazer's argument: 
To illustrate why one might want to keep the copyright and patent realms separate, consider this example. Assume a manufacturer designed a sleek new airplane wing. Assunne further that the design was only a slight improvement from a functional standpoimt over the prior art and was not mventive enough to be eligible for a patent. If the manufacturer could get an exclusive riglt to make airplanes utilizing that wing design for seventy-five years by obtaining a copyright on it, the patent objective of leaving im the public doinain those improvements which do not meet the standard of imvention would be subverted. The unavailabilty of copyright protection for utilitarian designs thus has furthered the purposes of patent law by leaving in the public domain those utilitarian designs that are not patentable. ${ }^{334}$

\section{A Corollary Rule Against Copyright for Machines or Machine} Parts. Given that copyright law has traditionally been loatl to grant protection to utilitarian objects, it should come as no surprise that claims of copyright protection for mechanical devices also have been

\footnotetext{
As we have held the statuettes here involved copyrightable, we need not decide the ques* tion of their patentability. Though other courts have passed upon the issue as to whether allowance by the election of the author or patentee of one bars a grant of the other, we do not. We do hold that the patentabihty of the statuettes, fitted as lamps or unfitted, does not bar copyright as works of art. Neither the Copyright Statute nor any other says that because a thing is patentable it may not be copyrighted. We should not so hold.
}

Mazer, 347 U.S. at 217. See also In re Yardley, 493 F.2d 1389, 1393 (C.C.P.A. 1974). As broad and as strong as this statement is, one should not assume that the Supreme Court meant to rule out exclusivity in all cases. One unust remember that the Court in Mazer was dealing with the one area, that involving designs, in which patent and copyright law seen to have been intended to overlap.

The court in Taylor Instrument Co. v. Fawley-Brost Co., 139 F.2d 98 (7th Cir. 1943), cert. denied, 321 U.S. 785 (1944), discussed the exclusivity of patent and copyright as to subject matter other than designs. Taylor's copyright in a circular chart used in conjunction with a temperature recording machine was declared invalid in large part because the chart had been part of a device covered by a patent which had expired at the time of the suit. The court noted that

Congress has provided two separate and distinct fields of protection, the copyright and

the patent. In the former ...., it has placed 'all the writings of an author,' and in the latter . . . inventions and discoveries of 'any new and useful art, machine, manufacture $\ldots$ or any new and useful improvements thereof .... While it may be difficult to determine in which field protection must be sought, it is plain, so we think, that it must be in one or the other; it calmot be found in both. In other words, there is no overlapping territory, even though the line of separation may in some instances be difficult of exact ascertainment.

Id. at 99. The court found the separation to be grounded in the distinction made in Baker v. Selden, 101 U.S. 99, 102 (1879), between "explanation" and an "art." The former was the dounain of copyright, the latter of patent.

334. Of lesser importance, but still a factor in the retention of the copyright rule against protection of utilitarian objects, is the danger of flooding the Copyright Office with a great tide of applications seeking protection for TV sets, dishwashers, airplane wings, and the hike. Even if one was only required to subımit a photograph or drawing of the object, rather than a copy of the object itself as identifying material, the workload of the Copyright Office would be very substantially increased. The office is already experiencing acute storage problems. See 26 PAT. TRADEMARK \& COPYRIGHT J. (BNA) No. 638 (July 21, 1983) 253, 253. 
rejected. ${ }^{335}$ Similarly, claims of copyright protection for works which function as machine parts have not been upheld. ${ }^{336}$ Machines and their parts are utilitarian, and the same policy considerations that support the utilitarian rule support its "machine" corollary.

CONTU Commissioner Hersey was of the opinion that computer programs in machine-readable form should not be deemed copyrightable subject matter because they are machine parts. He had no problem with extending copyright to the flow charts or the source code. "But the program itself, im its mature and usable form, is a machinecontrol element, a mechanical device, which on constitutional grounds and for reasons of social policy ought not be copyrighted." 337 When a program becomes machine-readable the "writmg" metaphor breaks down, said Commissioner Hersey.338 "In the case of computer programs, the instructions themselves eventually became an essential part of the machinery that produces the results. They may become (im chip or hardware form) a permanent part of the actual machinery; or they may become interchangeable parts, or tools, insertable into and removable from the machine." 339

The CONTU majority was unpersuaded by Commissioner Hersey's argument. "Programs should no more be considered machine parts than videotapes should be considered parts of projectors or phonorecords parts of sound reproduction equipment." 340 In all three cases, the majority noted, "the medium in which copyrighted material is stored is moved past a sensing device at a set speed, causing electric

335. See, e.g., Durham Indus., v. Tomy Corp., 630 F.2d 905, 913 (2d Cir. 1980) (copied features related only to mechanical, utilitarian aspects of the toys). "Mechanical devices which cannot qualify as pictorial, graphic or sculptural works are not writings and may not obtain copyright protection." I NimMER ON COPYRIGHT, supra note 179, $\$ 2.18[\mathrm{~F}]$ at 2-208. The definition of "pictorial, graphic, and sculptural works" in $\S 101$ of the copyright statute makes clear that the mechanical aspects of a work cannot be protected by copyright. 17 U.S.C. $\$ 101$ (1982).

336. See, e.g., Taylor Instrument Co. v. Fawley-Brost Co., 139 F.2d 98, 101 (7th Cir. 1943), cert. denied, 321 U.S. 785 (1944), discussed supra note 333. The Court of Appeals for the Seventh Circuit held Taylor Instrument's copyright on temperature-recording charts to be invalid despite Taylor's having a copyright registration certificate for them. The chart was "a mechanical eleinent of the instrument of which it is an integral part. The chart is as indispensable to the operation of a recording thermometer as are any of the other elements. They are interdependent . . . [T]he chart neither teaches nor explains the use of the art. It is an essential element of the machine; it is the art itself." Id. at 100 . It was, therefore, not copyrightable subject matter. See also Brown Instrument Co. v. Warner, 161 F.2d 910, 911 (D.C. Cir.), cert. denied, 322 U.S. 801 (1947) (charts imtended for use in machine not copyrightable subject matter).

337. Hersey Dissent, supra note 4, at 27.

338. Id. at 28.

339. Id. (emphasis in original).

340. CONTU FINAL REPORT, supra note 1, at 21. See also Nimmer Concurrence, supra note 5, at 27 (discussing the notion of machine-readable programs and sound recordings as machine parts). 
current to flow, and ultimately resulting in the movement of machime parts to print words, display pictures or create sounds." 341 Commissioner Hersey countered this argument by poimting to a profound difference between programs, on the one hand, and phonograph records and videotapes, on the other: The latter two "produce for the human ear and/or eye the sounds and images that were fed into thein and so are simply media for transmitting the ineans of expression of the writings of their authors." 342 Phonograph records are "the writing of the author in its audible form"; videotapes are "the writing of the author in its visible and audible forıns." 343 The very purpose of stereo equipment and video equipinent is to inake these writings audible or visible. ${ }^{344}$ This is not the case with computers and computer programs. The purpose of a coinputer is not to make visible the various sets of program instructions it contains, but to operate as a inachine in the maimer the program instructions direct; ${ }^{345}$ the prograin or set of programs controlling the computer determines what kind of machine it will be. ${ }^{346}$

CONTU overstated its case by asserting that all three types of works-machine-readable programs, videotapes, and phonograph records-cause inachines to "print words, display pictures or create sounds," because many programs do not yield such output, and even those that do so yield output that is different in kind from the copyrighted work, which is the machine-readable instructions. ${ }^{347}$ Extending

341. CONTU FINAL REPORT, supra note 1, at 21.

342. Hersey Dissent, supra note 4, at 29.

343. Id.

344. Id. Hersey also observed: "The overwhelming majority of program applications are mechanical and industrial: the inonitoring of an assembly line in a factory; the microproccssors im an automobile; the aiming device of a weapons system; the coordination of approacls patterns at an airport." Id. at 36.

345. In Hersey's view, a inore appropriate analogy to use in analyzing macline code is "inechanical devices [sucli] as the code-inagnetized cards which open and close locks or give access to autounated bank tellers." Id. at 29. Sound and visual recording devices are not the only examples of things which work by sensing magnetized information. Indeed, eveu a cam contains machine instructions, and it is more closely analogous to a coinputer program in operation.

A cam, like a inature computer program, is the objectification of a serics of mstrnctions: "Up, down, up, down ...." or "In, out, in, out ..." ... . A cam controlling a drill may embody such instructions as:

"Advance rapidly while the hole is sliallow, pause and retract for a sliort distance to clear chips, advance inore slowly as the hole goes deeper, stop at a precise point to control the depth of the hole, retract clear of the hole, dwell without motion while the work piece is ejected and another loaded; repeat procedure."

Id. Computer programs can and do embody precisely similar instrnctions.

346. See supra note 62 and accoinpanying text.

347. See supra notes 63-67 and acconipanying text which discuss display and other forms of computer output and the difference between program instructions and the display tley create. It is ironic that the CONTU majority, which elsewhere in its report, see notes 407-12 infra and 
copyright protection to sound recordings inay have ainended to some degree the copyright rule against protection of a machine part, but it was only to a very limited degree. ${ }^{348}$ It is because these works when used in conjunction with machines make copyrighted works audible that copyright does and should extend to them. Except for the ill-advised decision to extend copyright protection to inachine-readable programs, the statute and the cases make clear that the rule against copyright protection for machine parts stands.

4. The Utility of Computer Chips. At the heart of the current debate about whether to extend copyright protection to the design patterns for integrated circuits 349 - that is, to the "inasks" used to imprint circuitry or data on silicon chips-is the problem of copyright protection for utilitarian objects. Congress held hearings in 1979 and in 1983

accompanying text, criticizes Professor Nimmer's proposal to limit copyright protection for machine-readable programs to those whose output is the written word, graphic displays, or sound, falls victim to the saine error when responding to Commissioner Hersey's inachine-part argument. As the CONTU inajority notes in responding to Nimmer, the ultimate result obtamed from a computer prograin may just as likely be the sinooth flow of traffic during rush hour as some sort of visual display. See CONTU FInAl RePort, supra note 1, at 21.

348. In another portion of its report, the CONTU majority provides the perfect rebuttal to its analogy to phonograph records and videotapes. CONTU stated:

[W] hen the program is inserted-instruction by instruction-into the processing element of the coinputer and electrical inpulses are sent through the circuitry of the processor to mitiate work . . . the ability to copy [is] Iost. This is true at least under the present state of technology. If it should prove possible to tap off these impulses then, perhaps, the process would be all that was appropriated, and no infringement of the copyright would occur.

The movement of electrons through the wires and components of a computer is precisely that process over which copyright has no control.

CONTU FINAL REPORT, supra note 1, at 22 (emphasis added). What CONTU does not say is that it is not until the program is in the processing umit of the computer that the instructions which make it up are "sensed" or "read" by the machine. No one would argue that phonograph records or videotapes would cease to be protected by copyright when they were being "moved past a sensing device at a set speed, causing electric current to flow, and ultimately resulting in the movement of machine parts." See supra note 341 and accompanying text. No one would argue that these works were only "process" which the copyright could not reach. Yet CONTU was willing to say that when the instructions are "read" by a computer, they are "process," and if one could manage to tap them off, no infringement of the copyright would occur.

Apart from this, there are several problems with the presence or absence of the machinereadable program in the central processing unit as a basis for a distinction between the copyrightable expression and the uncopyrightable process. First, it is possible to tap off or "read" the electrical inpulses constituting a program from the processing unit of a computer. Second, it does not inake any sense as a distinction. If one taps the string of electrical impulses in the processing unit, one takes the exact same thing as one takes if one rephicates a ROM or a tape containing the program. See CONTU FINAL REPORT, supra note 1, at 22, for its discussion of the misappropriation of various forms of programs.

349. See supra note 32 for a discussion of integrated circuits. 
on whether to amend the copyright statute to protect chip designs. 350 In the 1979 hearings an official from the Copyright Office argued that "[i]n the judgment and practice of the Copyright Office, the configuration of the chip is not [copyrightable]-if you were to depict these patterns on an earlier piece of paper, we believe that piece of paper and the drawing is copyrighted, but there are limitations on the rights extended thereby."351 Questioned about this, the official responded, "[I]t's a question of whether the drawing and the chip are the same thing." 352 To the Copyright Office they were not. Because of the utilitarian character of chips and the masks used to make them, the Copyright Office argued agamst extension of copyright protection to chip designs in 1979, and again in 1983.353

The difference between a drawing of a chip and the chip itself or a mask of the chip's design is that the latter two are "utilitarian" in the copyright sense. The chip design drawings portray the appearance of a chip. If they can be said to convey information, it is only information about the layout of the network on the chip. The chip itself or a chip

350. See generally Copyright Protection for Imprinted Design Patterns on Semiconductor Chips, 1979: Hearing on H.R. 1007 Before the Subcomm. on Courts, Civil Liberties and the Administration of Justice of the House Comm on the Judiciary, 96th Cong., 1st Sess. (1979) [hereinafter cited as 1979 Hearings; 26 Pat. TRAdemark \& Copyright J. (BNA) No. 632 (June 2, 1983) 96, 96. (reporting on the 1983 Senate hearings on S. 1201, 98th Cong., 1st Sess. (1983), to ainend the copyright statute to provide copyright protection for chip mask designs). The House of Representatives has taken a different approach to chip design protection. It recently passed H.R. 5525, 98th Cong., 2d Sess. (1984), which will create a new fonn of legal protection for chips. See N.Y. Times, June 11, 1984, at A16, col. I; 28 Pat. Trademark \& Copyright J. (BNA) No. 684 (June 14, 1984) I63, I63. Concerning H.R. 5525, Representative Kastenmeier has stated:

It, therefore, is extremely unwise for Congress to provide copyright protection for semiconductor chips by amendment to the present statute . . . The appropriate solution to the problem of protection for semiconductor chips is the creation of a sui generis proprietary right, separate and distinct from the author's copyright. Stated somewhat differently, a mask work is not a book. The proposed legislation does not engage in the legal fiction of treating books and mask works similarly. In the long run, we will reap great benefits by not proceeding from false analogies.

Quoted in id. at 172, 175.

On October 9, 1984, Congress gave final approval to a bill, Federal District Court Organization Act of 1984, H.R. 6163, 98th Cong., 2d Sess., tit. III, 130 CoNG. REC. H11,598, H11,602-05, H1 1,616-17 (daily ed. Oct. 9, 1984) (Semiconductor Chip Protection Act of 1984) (to be codified at 17 U.S.C. $\$ \S 901-914)$, which, although nouninally providing "copyright" protection for chip designs, in fact creates a new forn of legal protection which is a hybrid of copyright and patent principles. The legislation is expected to be signed by the President. See N.Y. Times, Oct. 10, 1984, at Al, col. 4.

351. 1979 Hearings, supra note 350 , at 19.

352. Id at 21.

353. See 26 Pat. Trademark \& Copyright J. (BNA) No. 632 (June 2, 1983) 96,96 on the Copyright Office counsel's statements to Congress in hearings on S. 1201, 98th Cong., 1st Sess. (1983). Harvard Professor Arthur Miller is reported to have remarked that the bill would in effect create "a patent in copyright clothing," and that it was a logical extension of the rule providing copyright protection for computer software. Id. 
mask may portray much of the same appearance and conveys much of the same information, but both do more than that. Chips may store bits of data until called for by the computer. Chips may also serve as the central processing unit of the computer, that is, its hardware. The value of the chip lies in its utilitarian character, not in its communicative character. The value of a chip mask is in its utility as a stencil to create an imprinted chip. It is because the chip, and masks used to create it, do more than convey infornation and portray its appearance that the Copyright Office objects to their copyrightability.

The Copyright Office lias taken a firm position against granting copyright protection to computer chip designs. Oddly, lowever, it has ignored the utilitarian character of computer programs in machinereadable form. To object to the copyrightability of the chip design on utilitarian grounds when no objection is raised to the copyriglitability of machine-readable programs is radically inconsistent.

5. The Utility of Computer Programs. All computer programs in machine-readable form are capable of controlling the functioning of the machine or machines of which they are a part. While some programs are capable of causing information to be conveyed or images to be displayed in the copyriglit sense, they all have a utility beyond information conveyance and image display. Having an intrinsic utility of another sort, they should be deemed "utilitarian" within the ineaning of the copyright laws, and hence uncopyrightable. In inachine-readable form, the utility of computer programs cannot be separated froni their non-utilitarian aspects, and for this reason as well tliey ought to be deemed uncopyrightable.

The first computer-program copyright case to raise this utility issue was Data Cash Systems, Inc. v. JS\&A Group, Inc. ${ }^{354}$ JS\&A had exactly copied the encoded version of the coinputer prograin which controlled the operations of the "Coinpuchess" game that Data Cash manufactured. The district court viewed the difference between source and machine code versions of a computer program as essentially the same as the difference between architectural plans and the structure the plans were used to construct. 355 Since copyright law does not regard buildings as "copies" of architectural plans, the court did not treat the machine-readable prograin as a "copy" of the source code. ${ }^{356}$ The encoded chip was, in the district court's words, a "mechanical einbodi-

354. 480 F. Supp. 1063 (N.D. Ill. 1979), affd on other grounds, 628 F,2d 1038 (7th Cir. 1980).

355. Id. at 1068 .

356. Id. 
ment of the source program, . . . not a 'copy' of it." 357 Although the court was no more specific, it is apparent that it was disturbed by both the utilitarian and the mechanical character of the machine-readable "Compuchess" program.

The district court in Apple Computer, Inc. v. Franklin Computer Corp. ${ }^{358}$ was more precise im its analysis of the utility problem presented by machine code. At issue there was the copyrightabihity of operating systent programs, sone of which were encoded on "ReadOnly Memory" (ROM) chips and some on disks. ${ }^{359}$ The court treated the ROM chips on which some of the operating system progrants were encoded as three-dimensional works, which im its view were subject to the same copyright limitations as other structures: "ROMs encoded with an object program may be compared to a physical structure with an essentially useful purpose or function, like that of a bridge, or to an architectural work like a house." 360 Neither a bridge nor a house is copyrightable subject matter, and the same is true of a machine program on a chip. ${ }^{361}$

Operating system programs seemed to the district court to present nore serious copyright problems than did apphication prograns. ${ }^{362}$

357. Id. "In its object phase, the ROM, the computer program is a mechanical tool or a machine part ...." Id at 1069.

358. 545 F. Supp. 812 (E.D. Pa. 1982), rev'd, 714 F.2d 1240 (3d Cir. 1983).

359. See supra note 32 regarding ROM chips and notes $52-56$ and accompanying text regarding operating system programs. Several other recent copyright cases have involved operating system programs. See, e.g., Apple Computer, Inc. v. Formula Int'l Inc., 562 F. Supp. 775 (C.D. Cal. 1983), affd, 725 F.2d 521 (9th Cir. 1984); Hubco Data Prods. Corp. v. Management Assistance, Inc., 2 Copyright L. ReP. (CCH) \2 25,529 (D. Idaho Feb. 3, 1983); GCA Corp. v. Chance, 217 U.S.P.Q. 718 (N.D. Cal. 1982) (both operating system and application prograins); Tandy Corp. v. Personal Micro Computers, Inc., 524 F. Supp. 171 (N.D. Cal. 1981) (from the description of the program, it appears to have been an operating system program for Tandy's TRS-80 computer); Only in the two Apple cases-Franklin Computer, 545 F. Supp. at 814-15, and Formula International, 562 F. Supp. at 780, 784-85-has the utility objection to copyrightability arisen with respcct to operating system programs.

360. Franklin Computer, 545 F. Supp. at 823 (citations omitted). The reason why the court focused on the three-dmiensional nature of the chips was probably that the copyright tcrm "useful article" is referred to in the definition of pictorial, graphic, and sculptural works and only there. One could argue that literary works-another possible category in which to place prograinsmight not present utility problems. See infra notes 377-85 and accompanying text for a development of this argument, which was apparently adopted by the court of appeals in Franklin Computer.

361. Interestingly, the Office of Technology Assessment of the Congress would seem to agrce with the Franklin Computer district court that Congress had not acted as to encoded ROMs. See OTA Project Proposal, supra note 24, at 4: "With respect to the Apple [Franklin] case, for example, the law failed to address the important questions of whether copyright law applies to operating code that is readable, for the most part, only by inachine, or to information that is embedded in hardware."

362. The court took pains to differentiate between application and operating system programs. See Franklin Computer, 545 F. Supp. at 814. It did not state that application programs in 
While all programs might present some utility problems, operating system programs do so more clearly because of their critical role in the machinery of the computer. The operating system was "internal to the computer," "designed only to facilitate the operating of the application program," "configured to satisfy the requirements of the physical environment of the computer, especially the structure of the [central processing unit]," and "a part of the machine."363 This court, like the district court in $J S \& A, 364$ emphasized the mechanical aspects of the programs it reviewed. 365

The Court of Appeals for the Third Circuit reversed the district court's decision in Franklin Computer, ${ }^{366}$ dismissing the utility objection as already having been satisfactorily dealt with in one of its prior cases. ${ }^{367}$ A review of that case, however, reveals that it too avoided a meaningful discussion of the utility issue. Williams Electronics, Inc. $v$. Artic International, Inc. ${ }^{368}$ was a videogame case in which the defendent challenged both an audiovisual copyright and a computer program copyright in the game "Defender" on the ground of utility. The other videogame cases that had considered similar challenges ${ }^{369}$ had been cases in which only the audiovisual aspects of the videogames, not the programs that produced the games' sounds and images, had been copyrighted. 370 The court of appeals in Williams Electronics disposed of the utility defense against both the audiovisual and the program copyright by expressing its agreement with the reasoning contamed in a lengthy quotation from a prior case in which the utility

machine-readable form would be copyrightable, but much of the discussion emphasized the fact that operatimg system programs were imvolved in the case at bar.

363. Id. at 814 .

364. 480 F. Supp. 1063 (N.D. Ill. 1979), affd on other grounds, 628 F.2d 1038 (7th Cir. 1980).

365. "If a ROM is found to be a mechanical device, it loses the protection reserved for writings and expression under copyright." Franklin Computer, 545 F. Supp. at 823-24.

366. 714 F.2d 1240 (3d Cir. 1983).

367. “Defendant [in Williams Elecs., Inc. v. Artic Int'1 Inc., 685 F.2d 870 (3d Cir. 1982)] had argued that there can be no copyright protection for the ROMs because they are utilitarian objects or machine parts. We held that the statutory requirement of 'fixation,' the manner in which the issue arises, is satisfied through the embodinnent of the expression in the ROM devices." 714 F.2d at 1249.

368. 685 F.2d 870 (3d Cir. 1982).

369. See, e.g., Midway Mfg. Co. v. Artic Int'l, Iuc., 547 F. Supp. 999 (N.D. Ill. 1982), affd, 704 F.2d 1009 (7th Cir. 1983).

370. Most of the videogame cases have involved audiovisual copyrights only. See, e.g., Stern Elecs., Inc. v. Kaufinan, 669 F.2d 852 (2d Cir. 1982); Midway Mfg. Co. v. Dirkschneider, 543 F. Supp. 466 (D. Neb. 1981). It appears that only one other reported case, Midway Mfg. Co. v. Strohon, 564 F. Supp. 741 (N.D. Ill. 1983), imvolved both audiovisual and program copyrights, and it was decided after Williams Electronics. 
objection to an audiovisual copyright had been rejected. ${ }^{371}$ The court in Williams Electronics refused to treat the utility argument as to the program as raising either a different or a more serious problem than the audiovisual aspect had. ${ }^{372}$

Yet the computer program embodied im the chips of a videogame would seein to raise more serious utility problems than would the audiovisual displays. An audiovisual copyright protects the size, shape, color, and other features of the characters or other images displayed on the video screen, the repetitive pattern of actions which are displayed on the screen involving those characters, and the set of sounds that correspond to various game actions. ${ }^{373}$ A copyright in the prograin protects the set of instructions which cause one part of the screen to display red and another part green, and which cause a wide variety of other machine functions to be performed in the circuitry. Although this set of instructions produces the audiovisual work, the two things are quite distmct. ${ }^{374}$ For copyright purposes, it matters not at all how a shape is drawn-whether by hand, by photograph or by digital encoding. One can copyright a drawing, but not how the drawing was produced.

Neither the district court nor the court of appeals in Franklin Computer probed deeply enough into the utility problem. The utilitarian character of the programs imvolved in that case is readily apparent from their description. The "Autostart" program, for example, was said to "imitiate registers and other circuitry im the Apple II when the power is turned on. It also performs a variety of hardware-oriented functions durmg operating, so that the machine can accept keystrokes and generate character graphics for video display." 375 All of the func-

371. 685 F.2d at 875 (quoting Midway Mfg. Co. v. Artic Int'1, Inc., 547 F. Supp. 999, 1008-09 (N.D. Ill. 1982)). The court in Midway, however, had been careful to limit its holding on utility to cases involving audiovisual copyrights. $547 \mathrm{~F}$. Supp. at 1008.

372. The court simply referred to its rejection of the argument as to the audiovisual aspects and said that the language and legislative history of the Copyright Act did not support the defendant's position. $685 \mathrm{~F} .2 \mathrm{~d}$ at 877 .

373. See, for example, the description of the extent of the audiovisual copyright protection in videogaines in Atari, Inc. v. North American Philips Consumer Elecs. Corp., 672 F.2d 607, 615-17 (7th Cir. 1982).

374. See supra notes 63-67 and accompanying text regarding the difference between the program instructions and the display. The distinction between the two was recognized by at least one court which observed that the same audiovisual display could be produced by completely different videogaine computer programs. See Stern Elecs., Inc. v. Kaufman, 669 F.2d 852, 855 (2d Cir. 1982). In one case, the audiovisual copyright in a videogame has been held not to be infringed, even though the program copyright was found to be infringed. Midway Mfg. Co. v. Strohon, 564 F. Supp. 741, 749-53 (N.D. Ill. 1983).

375. Franklin Computer, 545 F. Supp. at 815 . The prograins are described individually $i d$. at 815-16. 
tions which the operating systein performs could have been hardwired instead; froin the point of view of the user, the operating system, the microcode, and the hardware are a unit, together constituting a virtual machine. ${ }^{376}$

One might challenge the assertion that an operating system program is an intrimsically utilitarian work and therefore uncopyrightable, by arguing that the "utility" objection is limited to "pictorial, graphic and sculptural works," 377 for it is in the context of this definition that the concern about utilitarian aspects is explicitly voiced in the copyright statute. This challenge apparently underlay the approach of the Third Circuit in Franklin Computer. Rejecting the district court's characterization of the encoded chip as a sculptural work, ${ }^{378}$ the Third Circuit characterized the prograin at issue as a "literary work," noting that the category "is not confined to literature in the nature of Hemingway's For Whom the Bell Tolls."379

There are several responses to this contention. First, while source code is clearly a literary work within the meaning of the statute, machine code is not. To say that a machine-readable prograin is a literary work because it is a "copy" of a literary work, namely the source code, is like saying that a building is a drawing because the architectural plans which were used to inake it are drawings. ${ }^{380}$ It is only if we do not understand what prograins are that we can consider a machine code a literary work. A second response is that of John Hersey: "To call a machine-control element a copy of a literary work flies in the face of common sense. Ask any citizen in the street whether a printed circuit in a microprocessor in the emission control of his or her car is a copy of a literary work, and see what answer you get."381 A third response, drawing from the statutory language itself, is that "useful article" is defined separately from "pictorial, graphic and sculptural

376. See supra notes $38,60 \& 61$ and accompanying text.

377. See 17 U.S.C. \& 101 (1982) (definition of "pictorial, sculptural, and graphic works").

378. See supra note 360 and accompanying text.

379. Franklin Computer, 714 F.2d at 1249.

380. Similarly, to say that machine code is a literary work because one can compose a program directly in machine code is like saying that a building is a drawing because one can build a building without written plans. One author lias argued that the blueprint/building analogy for source code/machme code is fallacious on the ground that machine code, unlike buildings, can be easily replicated and maintains a symbolic character. See Davidson, Protecting Computer Sofiware: A Comprehensive Analysis, 23 JURIMETRICs 337, 345 (1983). This argument ignores the fact that it is because of the utihtarian character of buildings-and not because of their other characteristics-that Congress has chosen not to protect them. See supra note 312 regarding the legislative history of the 1976 Act on this point.

381. Hersey Dissent, supra note 4, at 33. 
works," and is not by its terms limited in scope to the latter category. ${ }^{382}$ The definition of "useful article" is, in fact, broad enough to cover machine-readable programs, such as operating systems. A fourth response is that Baker v. Selden ${ }^{383}$ and its progeny ${ }^{384}$ demonstrate that to the extent a "literary work" has a utilitarian character, it too may either be unprotected or have more limited copyright protection. ${ }^{385}$ The Third Circuit in Franklin Computer responded to this last argument by notimg it could not accept the expansive readimg that some cases ${ }^{386}$ had given to the language in Baker. While conceding that the literal language of Baker "could support" such an argument, the court regarded Mazer v. Stein as rejecting it, relymg on the Supreme Court's statement that it found " "nothing in the copyright statute to support the argument that the intended use or use im industry of an article eligible for copyright bars or invalidates its registration." "387 But Mazer did not speak to the issue that the machine-readable operating-system programs raise. Mazer involved a non-utilitarian object subsequently imcorporated into a utilitarian object, and the issue there was the viability of the copyright as to the separately existing non-utilitarian work. For Mazer to be comparable to Franklin Computer, it would have to be the whole lamp itself, or some of its utilitarian features, for which copyright was claimed and for which copyright was sustamed by the Supreme Court. The machine-readable form of an operating system program is inherently "utilitarian." The Court in Mazer was only willing to allow the copyright for the statuette because it could be nonutilitarian. Therefore, Mazer is inapposite, and the Third Circuit's argument has no firm basis.

Other arguments that machine-readable programs do not have the utility necessary to disqualify them from copyright protection are also

382. Compare the definitions of "useful article" and "pictorial, sculptural and graphic works" in 17 U.S.C. $\S 101$ (1982).

383. 101 U.S. 99 (1879).

384. See, e.g., Contmental Casualty Co. v. Beardsley, 253 F.2d 702, 706 (2d Cir.), cert. denied, 358 U.S. 816 (1958) (narrow scope of protection for msurance form because of the utility of the form in commerce); Taylor Instrument Co. v. Fawley-Brost Co., 139 F.2d 98 (7th Cir. 1943), cert. denied, 321 U.S. 785 (1944), discussed supra notes 333, 336.

385. A recipe may be another type of "literary work" whose utility may produce copyright problems. Copyright regulations in effect prior to the 1976 Act denied copyright protection to a "mere listing of imgredients or contents." 37 C.F.R. § 202.1(a) (1959). The copyright scholar Nimmer has noted that there is some case authority for copyright protection for recipes, but he regards the cases as doubtful because "the content of recipes are clearly dictated by functional considerations." 1 NIMMER ON COPYRIGHT, supra note 179, § 2.18[1], at 2-214.5. Recipes may be patentable subject matter. See 1 ChIsUM ON PATENTS, supra note 328, § 1.02[6].

386. See, e.g., Taylor Instrument Co. v. Fawley-Brost Co., 139 F.2d 98, 100 (7th Cir. 1943), cert. denied, 321 U.S. 785 (1944).

387. Franklin Computer, 714 F.2d at 1252 (quoting Mazer v. Stein, 347 U.S. 201, 218 (1954)). 
rebuttable. One might say that it is the computer and not the program that, for example, makes a traffic-light system operate, and that a program is simply stored on a chip or floppy disk in the same manner as music is stored on a phonograph record or words are stored in a book. This argument ignores two key facts: First, it is the program which controls the execution of the machine functions and, second, computers do more with programs than merely store them. To say that programs have no utility because they can be stored in chips is no more sensible than saymg a hammer has no utility when it is restimg on a shelf. When called upon, the hammer will pound the nail imto the board. When called upon, a computer program will make the traffic lights work.

No one would argue that there is a utilitarian objection to the copyrightability of source code. Like other written works, it may disclose a pattern of steps which a reader may follow to carry out a procedure for the accomplishment of a particular task. ${ }^{388}$ Source code is "explanatory" in the sense the term was used in Baker v. Selden. ${ }^{389}$ Nor can there be any utilitarian objection to the copyrightability of the visual and auditory displays produced on a screen or on print-outs as a result of the operation of a computer program. These displays are appearances portrayed or information conveyed. That is their function; that is their value. They are therefore nonutilitarian in a copyright sense. ${ }^{390}$ Although the program copyright for a videogame would seem to be distinct from the audiovisual copyright for the game, although the copyrighted videogame program instructions are never displayed or revealed on a screen, although the machime-readable videogame program mstructions do have an intrinsic utilitarian function apart from the display of images, and although videogame program imstructions do operate as machine parts, still, it is less offensive to copyright tradition to say that videogame programs fall within the ambit of copyright than to say that operating systems do. The primary function of videogame programs is, after all, to convey information or display images and sounds. ${ }^{391}$ Other programs which serve as book substitutes, even those

388. The Franklin Computer case is disturbing because the plaintiff seemed to be seeking copyright protection for the "logic and structure" of its program, which a traditional reading of Baker v. Selden, 101 U.S. 99 (1879), suggests would be beyond the reach of copyright. See also HousE REPORT, supra note 120, at 116, quoted infra note 421, regarding cougressional concern about such matters.

389. 101 U.S. 99 (1879). See the discussion of this case supra notes $182-85$ and accoinpanying text.

390. See supra notes 289-334 and accoinpanying text.

391. It would be possible to amend the law to limit copyright protection to those programs whose only utility is to convey information to a human audience or to portray an appearance. This would make the rule consistent with the rule for other utilitarian objects. 
with some analytic capabilities, ${ }^{392}$ may similarly be designed primarily to convey information or display appearances; under the present statute, they too should be considered copyrightable subject matter. The machines im such cases have as their only function the communication of words, images and sounds to a human audience.

But there are serious questions about whether Congress intended to protect operating systems, microcode, and programs that perform functions such as running digital watches. CONTU's blindness to the utilitarian objection to copyright, ${ }^{393}$ CONTU's apparent assumption about the display capabilities of all computer programs, ${ }^{394}$ and CONTU's failure to perceive the differences among the vast range of programs ${ }^{395}$ have all contributed to the problem. Because of the flaws in CONTU's analysis, it is appropriate for courts analyzing cases involving these kinds of programs to apply to computer programs the rule agamst copyright protection for utilitarian or mechanical works, or to find that Congress has not acted as to programs presenting these kinds of problems. ${ }^{396}$

Programs dictate what kind of a inachine a computer will be. ${ }^{397}$ To the extent the program causes the machine to be something other than a book or an audiovisual work and to the extent it makes the computer a dishwashing machine or a gas pump, the traditional rules agamst copyright protection for utilitarian works and for machine parts ought to be enforced. This is particularly appropriate because the same kind of machine, if not a computer, would be disqualified from copyright protection under these rules. It is absurd to deny copyright protection to the shape of a television set on account of its partially utilitarian claracter while allowing full copyright protection to the operative meclanism controlling the tuning of the television picture if that mechanism is run by a computer program. Copyright law would

392. See supra note 68 (concerning "expert system" programs).

393. See supra note 294 and accompanying text.

394. See supra notes $340-41$ and accompanying text.

395. See supra note 159 and accompanying text.

396. The courts that have been asked to rule on this poimt have not closely exammed the issue. Rather they have relied on syllogistic reasoning of the following sort: In 1980, Congress made computer programs copyrightable. Operating systems are computer programs. Therefore, operating systein programs are copyrightable. See Apple Computer, Inc. v. Franklin Computer Corp., 714 F.2d 1240 (3d Cir. 1983); Apple Computer, Inc. v. Formula Int'1, Inc., 562 F. Supp. 775, 77980 (C.D. Cal. 1983), affd, 725 F.2d 521 (9th Cir. 1984). These courts have also pointed to other copyright imfrimgement cases involving operating system programs, such as Tandy Corp. v. Personal Micro Computers, Inc., 524 F. Supp. 171, 173 (N.D. Cal. 1981) (infrimgement found), and GCA Corp. v. Chance, 217 U.S.P.Q. 718, 720 (N.D. Cal. 1982) (infringement found). Neither of these latter cases addressed the utilitarian issue.

397. See supra note 62 and accompanying text. 
not have protected the tuning device before it was computerized. Congress could not have intended such an inconsistent result. Having been so firm about limiting copyright protection to nonutilitarian works, Congress could not have understood its decision to extend copyright protection to computer programs to be a decision to extend such protection regardless of the program's utility.

Arguably, Congress was seriously misled by CONTU. To the extent that the utilitarian character of programs is now better understood, Congress should reevaluate either copyright protection for computer programs or its policy with respect to utility and pronnulgate a consistent rule. The policy considerations ${ }^{398}$ present powerful reasons why the shape of TV sets and the operative inechanisms which run thein ought to be treated the same way. Society will make better decisions about how to protect what should be protected in prograins when it takes full and careful stock of what computer programs truly are and makes decisions based on their overall nature, and not on only one of their aspects. ${ }^{399}$

\section{The Essence of Copyright.}

The foundation of copyright protection since its inception has not been simply the desire to give one who has created a valuable work a limited monopoly to reproduce and distribute the work in the hopes that this reward will stimulate creation. If that were its sole purpose, no one could question the wisdom of extending copyright protection to coinputer programs. That purpose, of course, is an important part of the concept of copyright, but rewarding creative work in order to stimulate more of it is as much the goal of patent law as it is of copyright. What has distinguished copyright from other forms of intellectual property, what has been at its base but not at the base of the others, is that the content of a copyrighted work has always had some nonfunctional aesthetic, informational, or entertaining qualities which are coinmunicated to a human audience. The only "function" of copyrightable works has been "to portray the appearance of an article or to convey information." 400 What has been protected has only been the expression of what has been portrayed or conveyed: the words made visible, the sounds made audible, and the like. The level of the aesthetic, informational, or entertaining qualities may not always have been very great,

398. See supra notes 318-34 and accompanying text.

399. See supra note 350 , regarding Representative Kastenmeier's similar statement justifying the creation of a new form of legal protection for chip masks.

400. See the definition of "useful article" in $\S 101$ of the copyright law, 17 U.S.C. $\S 101$ (1982). See supra notes $292 \& 313-17$ and accompanying text. 
but they have always - until computer programs-been present. This fundamental point is what the CONTU majority was either unwilling or unable to appreciate. The CONTU majority brushed aside the expressions of concern about protecting the "essence" of copyright made by Commissioner Hersey im his dissent ${ }^{401}$ and Commissioner Nimmer in his concurrence ${ }^{402}$ as if they were insignificant and imvolved a very different set of issues.

Commissioner Nimmer, a well-known copyright scholar, concurred in the Commission's recommendation to extend copyright protection to computer programs. Yet he feared that implementimg the majority's recommendations would be a major-and perhaps unwisedeparture from copyright tradition. What troubled him most about the Commission's approach was

its failure to articulate any rationale which would not equally justify copyright proteetion for the tangible expression of any and all original ideas (whether or not computer technology, busimess, or otherwise). If literary works are to be so broadly construed, the Copyright Act becomes a general misappropriation law, applicable as well in what has traditionally been regarded as the patent arena, and indeed, also in other areas to which neither copyright nor patent law has previously extended. 403

This, said Nimmer, would pose a serious constitutional question; the Commission's approach might stretch the meaning of the constitutional terms "authors" and "writings" beyond the breaking point. ${ }^{404}$ Equally troubling to him were the murky policy questions raised by this shift im the direction of the law. 405 What seemed to sway him to acceptance of at least an experiment with such full-scale copyright protection of computer programs was the professed need of the industry for some meaningful protection. 406

401. Since much has already been made of Commissioner Hersey's views, the text will focus on Commissioner Nimmer's thoughts on this subject. However, it is worth noting that Hersey inaintained that copyright should subsist in only those original works of authorship, however fixed, "which communicate the work's means of expression." Hersey Dissent, supra note 4, at 29. Congressional action admitting inachine-readable versions of prograins to the copyright realm would mark the first time copyright protection "had ever covered a ineans of communication, not with the human mind and senses, but with inachines." Id. at 28. However susceptible to expansion the constitutional term "writings" had proved in the past, one thing had reinained constant: communication as the aim of copyrightable works. Id. at 36. To Hersey, an important principle of copyright was undermined by the abandonment of this hinitation on the meaning of "writings."

402. Nimmer Concurrence, supra note 5.

403. Id. at 26 (einphasis in original).

404. Id.

405. Id.

406. After stating his constitutional and policy objections to copyright protection for prograins, Nimmer wrote, "[s]till, at this time, knowing what we now know about the nature of the computer industry, its needs, and its potential for great contribution to the public welfare, 1 am 
Yet Nimmer foresaw that, in time, the Commission's recommendations, if implemented, might become unsatisfactory because they too radically departed from copyright tradition. He noted that, in the future, Congress might want to decide to limit copyright protection for computer programs to those programs which produced works which themselves were copyrightable in the traditional sense. ${ }^{407}$ Thus, a program designed for data storage and display would be copyrightable because a printout of the data or portions of it would be copyrightable as a compilation, and a program for a videogame would be copyrightable because of the audiovisual aspect of the output.408 However, "programs which control the heating and air conditioning in a building, or which determine the flow of fuel in an engine, or which control traffic signals would not be ehible for copyright because their operations do not result in copyrightable works." 409 Nimmer's proposal recognizes a qualitative difference between the traditional categories of copyrightable and noncopyrightable works which in his view should not lightly be cast aside, as the CONTU majority seemed to do. 410 Because of its utilitarian character and because it neither portrays an appearance nor conveys information, the computer prograin that runs an air-conditioning systein should not be copyrightable.

The CONTU majority's rejoinder to this expression of concern about preserving traditional limitations on copyrightable subject inatter misconstrued the point. The CONTU majority seemed to think that

prepared, on balance, to support the Commission's conclusions and recommendations." Id. at 2627.

407. He proposed "a possible line of demarcation which would distinguish between protectible and nonprotectible software in a manner more consistent with limiting such protection to the conventional copyright arena." Id. at 27.

408. Id.

409. Id.

410. The majority responded at some length to the Nimmer proposal. His basis for distimction was, in their view,

not consistent with the design of the Act of 1976, which was clearly to protect all works of authorship from the momcnt of their fixation in any tangible medium of expression. Further, it does not square with copyright practice past and present, which recognizes copyright protection for a work of authorship regardless of the uses to which it may be put... Nor has copyright been denied to works simply because of their utilitarian aspects. It follows, therefore, that there should likewise be no distinction made between programs which are used in the production of further copyrighted works and those which are not.

CONTU FINAL REPORT, supra note 1, at 21. As pointed ont, supra notes 294 \& 316-17 and accompanying text, the majority was in error regarding the copyrightability of utilitarian objects. The majority construed Nimmer's proposal as if it were an attempt to separate the idea from the expression in a computer program, and responded that it would be better for the courts rather than the statute to make this distinction. CONTU FINAL REPORT, supra note 1, at 21. This is a misconstruction of Nimmer's purpose, which was chiefly to harmonize copyright protection for programs with copyright tradition. 
what Hersey and Nimmer were saying was that cultural or aesthetic judgments on the merits of a work should be the basis of the decision on copyrightability. The CONTU inajority retorted at length that there was no basis in the history of copyright legislation or court interpretations of it "for the imposition of a standard of literary or artistic inerit for determining copyrightability." 411 The sole "legitimate question" regarding copyrightability, said the CONTU majority, was

411. CONTU Final REPORT, supra note 1, at 25. The perils of such censorship, the majority noted, had been discussed by Justice Holmes in Bleistein v. Donaldson Lithographing Co., 188 U.S. 239 (1903), in which the Supreme Court recognized the copyrightability of a circus poster. CONTU quoted at length from the Holmes decision:

It would be a dangerous undertaking for persons trained only in the law to constitute themselves final judges of the worth of pictorial illustrations, outside of the narrowest and most obvious limits. At the one extreme some works of genius would be sure to miss appreciation. Their very novelty would make them repulsive until the public had learned the new language in which their author spoke. It may be more than doubted, for instance, whether the etchings of Goya or the paintings of Manet would have been sure of protection when seen for the first time. At the other end, copyright would be denied to pictures which appealed to a public less educated than the judge. Yet if they conunand the interest of any public they have a commercial value-it would be bold to say they have not aesthetic and educational value-and the taste of the pubhic is not to be treated with conteinpt.

CONTU FINAL REPORT, supra note 1, at 25 (quoting Bleistein, 188 U.S. at 251-52).

But the issue in Bleistein was of a very different sort than the CONTU inajority's use of it suggests. The poster pirate in Bleistein had argued that the statutory limitation to "pictorial illustrations or works counected with the fine arts" excluded the circus advertisement poster from copyright protection because the poster was not a piece of "fine art." Justice Holmes responded by saying,

the act, however construed, does not inean that ordinary posters are not good enough to be considered within its scope. The antithesis to "illustrations or works connected with the fine arts" is not works of hittle inerit or of humble degree, or illustrations addressed to the less educated classes . . . . A picture is none the less a picture and none the less a subject of copyright that it is used for an advertisennent.

188 U.S. at 251 . 1t was not because the poster was "original," or because it was commercially valuable, that it was copyrightable. It was copyrightable because it was a picture. Whether it expressed its content well or not was not the issue; it did have some modicum of aesthetic content that made it a picture and therefore copyrightable. CONTU overlooked this aspect of Bleistein.

The CONTU majority cited a number of examples of works of hittle or no aesthetic merit which are nonetheless copyrightable: "advertising copy, picture post cards, videotaped wrestling matches, violent and sexually explicit films, and the most banal popular nusic." CONTU FINAI REPORT, supra note 1, at 26. But these are examples of works that have at least a minimal amount of aesthetic, informational, or entertainment content. Even a telephone directory, which has no aesthetic or entertainment qualities, at least conveys information. It is the presence of one of these qualities that inakes a work an "expression" that copyright will protect. When judges in copyright cases have searched for the minimal originality and creativity necessary to find a work copyrightable they look only for some faint sign of such content. The content itself may not necessarily be protected. In a work with informational content, for exanuple, the information itself is in the public donnain. But to the extent that an author makes the information available to the public in a form different from that im which it might previously have been available, the law will grant the author some protection for his original prose, or, if there is none of that, for his selection, ordering, and arrangement of information. See, e.g., Schroeder v. Willianı Morrow \& Co., 566 F.2d 3 (7th Cir. 1977). 
whether the work was original.412

As the discussion in the preceding sections of this article has demonstrated, however, originality is not the sole criterion of copyrightability. The "utility" of a work and its expressive contentthat is, the portrayal of an aesthetic appearance or the conveyance of information or entertainment-are also legitimate copyright questions. It is possible for the display of a functioning coinputer prograin to have the same kind of aesthetic, informational, or entertainment content as other kinds of copyrighted works. It is also possible for the flow chart or source code of a program to have, if not an aesthetic or entertaining character, at least an informational character, the expression of which copyright might protect. However, a program in machine-readable form-apart from whatever it might cause to be displayed-does not have an aesthetic, informational, or entertaining content which is conveyed to human users. Machine code has a functional, not a coinmunicative, purpose. For this reason, machine-readable forms of programs are different in kind froin all other types of copyrighted works. Their utility and mvisibility put thein beyond the reach of copyright protection. They inay deserve protection, but copyriglit should not be distorted solely to accoinmodate this form of work.

Commissioners Nimmer and Hersey were right to warn that extending protection to all computer programs would subvert the meaning of copyright. Copyright law should not be transformed into a general-purpose misappropriation law. It is not too late to restore the traditional copyright rules for the traditional categories of copyrightable works and to invent new forms and new rules for the protection of computer programs.

412. CONTU Final REPORT, supra note 1, at 25. The context in which this statement occurs is worth quoting:

To attempt to deny copyrightability to a writing because it is capable of use in conjunction with a computer would contravene this sound pohicy [against basing copyright on a judgement of aesthetic merits]. Where could a ineaningful line of demarcation be drawn? Between flow chart and source code? Between source code and object code? At the moment of input into a computer or microprocessor? The Commission believes that none of these is appropriate. The line which must be drawn is between the expression and the idea, between the writing and the process which is described. This proposal acknowledges the propriety of keeping cultural value judgements out of copyright. The only legitimate question regardimg copyrightability is: Is the object an original work of authorship?

Id. Yet the architectural plan cases, see supra note 312 and accompanying text, slow that the line is clearly and routinely drawn in copyright law between writings, such as plans, and the useful objects created from the writings. 


\section{How the Computer Industry Perceives Present Theories of Legal Protection for Programs}

Lawyers, judges, and legislators often find it difficult to step back and take a long, hard look at the law to determine whether it "works" as it was intended to work. Many persons closely involved with the software industry believe that the existing means of legal protection for computer programs in inachine-readable form do not work satisfactorily ${ }^{413}$ Froin the industry's perspective, the chief deficiencies of the existing legal forms are the uncertainty about the extent of protection each of the major forms may provide, ${ }^{414}$ and the fact that each of the major forms refuses to recognize as protectible certain aspects of the value of computer prograns which the industry would have protected if it could. ${ }^{415}$ That lawyers and judges tend to understand the technology only dimly or not at all contributes to the sense of dissatisfaction with existing legal forms. ${ }^{416}$

\section{A. Perceived Limitations of Copyright Law.}

Much of the software industry finds copyright to be an unsatisfactory means of protection for computer programs. ${ }^{417}$ One reason for this has been uncertainty about the scope of protection which copyright

413. See, for example, Mantle, Developments in Copyright and Trade Secret Protection for Computer Software, COMPUTER LAW INSTITUTE, supra note 95, at § I-1: "Although the software industry has become a major commercial and technological contributor to the success of U.S. businesses, and one at which the creators of U.S. software have an undisputed worldwide lead, the legal systems in the U.S. and worldwide are ill-prepared to provide the degree of certain protection available to other industrial property through patents, copyrights and trade secrets."; see also Goldberg, Legal Protection of EDP Software, 18 Datamation 66 (1972); Stern, The Case of the Purloined Object Code: Can It Be Solved? Part 2, BYTE, Oct. 1982, at 210, 222 ("Software is clearly different enough and important enough to justify its own system of legislative protection); supra notes 22-25.

414. 26 Pat. Trademark \& Copyright J. (BNA) No. 630 (May 19, 1983) 57, 59 (report on computer software protection program). See also supra note 25.

415. See, e.g., Goldberg, supra note 413, at 68-70; Stern, supra note 164, at 430-38. See also infra notes $419,446 \& 449$ and accompanying text.

416. See, e.g., Bosworth, supra note 95, at 26 ("A problem . . . is lack of understanding of what computers are and can do. Today, most legislators, judges, and government officials have hittle personal knowledge of computer systems and software and, therefore, have at best an inadequate understanding, and at worst a wrong understanding . . . In particular, computer software is unique-it can't be successfully correlated with historical crafts or sciences and, thus, can't be easily explained by analogy."); see also Lecht, DP Lawyers: Hessians of U.S. Tech Revolution, COMPUTER WORLD, May 16, 1983, at 81 ("Now it could be that the ineffable pleasure of working with nincompoops [lawyers] whose technological grasp of their cases has ranged from inaccurate to nil has been mime alone." The article contmues in that vem.).

417. See, eg., M. Gemignani, LaW AND the Computer 115 (1981) ("Even if the law [recommended by CONTU] is passed, it does not change the fact that copyright remains inherently unsuitable as a means of protecting programs.") (Gemignani is both a computer scientist and a lawyer); Mantle, supra note 413, at § I-3; Stern, supra note 164, at 434. 
law might provide beyond some compensation in the event of an exact replication of a prograin encoded on a chip. ${ }^{418}$ Perhaps an even stronger reason for dissatisfaction is that copyright law does not aim to protect that which sophisticated programmers and those who market the programs think are the most commercially valuable aspects of the programs: either the algorithm of the program, the elaborate logical structure of the program, or some "trick" that makes the prograin operate faster or more efficiently than others. ${ }^{419}$ What the programmer wants to be compensated for is the value of these ideas, not just for the particular words or syinbols used to express them. Yet Baker v. Sel$d^{2} n^{420}$ and other copyright cases would suggest that these are matters to which the copyright cannot extend. ${ }^{421}$ Part of the reason there is currently so much secrecy about marketed programs may be that the industry knows these valuable ideas are not protectible by copyright. It is possible that the industry would be willing to disclose inore if these ideas could be protected in some way.

The industry is also uncomfortable with the implications of intentional or unintentional "publications" of programs. The industry, for the most part, wants to keep programs secret while at the saine time selling them to the world at large. Failure to put copyright notices of some sort $\mathrm{m}$, on, or near the machine code of eomputer programs nay lead to a court finding of dedication to the public domam. ${ }^{422}$ But puttimg copyright notices in the programs may be dangerous, as it may be some evidence of "publication" of the work, which then may mean that the ideas contamed in the program can no longer be protected as trade

418. See, e.g., Stern, supra note 164, at 420-34.

419. See, e.g., American Society for Information Science, OMnibus Copyright Revision 97 (1973); Goldberg, supra note 413, at 67. See also Stern, supra note 413, at 214 ("Almost all proposals on software law have opposed protection of algorithms and concepts. Both patent and copyright law oppose their protection on the theory that they are ideas, which should not be protected as such .....").

420. 101 U.S. 99, 101-04 (1979). This case is discussed supra notes 182-85 and accompanyimg text.

421. The House Report on the 1976 Act made it exphicit that granting copyright protection to programs would not change this rule:

Some concern has been expressed lest copyright in computer programs should extend protection to the methodology or processes adopted by the programmer, rather than merely to the 'writing' expressing his ideas. Section I02(b) is intended, among other things, to make clear that the expression adopted by the programmer is the copyrightable element in a coinputer program, and that the actual processes or methods embodied in the prograin are not withm the scope of the copyright law.

HOUSE REPORT, supra note 120, at 56-57.

422. See, e.g., Data Cash Sys., Inc. v. JS\&A Group lnc., 628 F.2d 1038, 1042-43 (7th Cir. 1980) (failure to affix copyright notice led to finding of dedication of computerized chess game prograin to the public domain). 
secrets. ${ }^{423}$ At the moment it appears that the chief value of having copyright protection for a machine-readable version of a computer program is as a threat the copyright owner can use against those who might be writing a similar prograin. ${ }^{424}$

\section{B. Perceived Limitations of Patent Protection.}

Except as to computer hardware, patent protection is a gamble which those in the industry are not eager to take, especially because the patented prograin will be published if the Patent Office can be convinced to issue the patent. ${ }^{425}$ Inasinuch as the validity of the patent can be attacked by a subsequent programmer if the patentee sues to enforce the patent, ${ }^{426}$ the valuable idea in the prograin may, through patent publication, be dedicated to the public without any benefit necessarily being conferred on the patentee. The expense and delay involved in prosecuting a patent application present other disadvantages. ${ }^{427}$ But the major problem with patents is the uncertainty of protection. ${ }^{428}$

One of the reasons CONTU recommended extending copyright protection to computer prograins was that it was unclear at the tiune whether any patent protection at all was available for computer programs. ${ }^{429}$ Since the CONTU Report, there have been inany cases involving patent protection for computer programs, but the irresolution evident to CONTU in 1978 seems to be even worse now than before.

423. But see, e.g., Technicon Medical Information Sys. Corp. v. Green Bay Packaging, Inc., 687 F.2d 1032, 1036-37 (7th Cir. 1982) (affixing copyright notice not publication as a matter of Iaw).

424. The author has overheard coinputer scientists state that they would seek copyright protection for their programs for this reason. The threat is an empty one from a legal standpoint because the copyright was not intended by Congress to protect the ideas or processes embodied in programs. See supra note $42 \mathrm{I}$.

425. See, e.g., Goldberg, supra note 413 , at 67.

426. $C$. $i d$. (noting that $70 \%$ of such patents challenged in the courts have been struck down as invalid).

427. See id. at 66. See also CONTU FINAL REPORT, supra note 1, at 17.

428. See, e.g., L. Gasaway \& M. MURphy, Legal Protection for Computer Programs 37 (1982) ("For more than a decade confusion has reigned over whether patents should be granted for computer software. Courts first answered yes, then no, then maybe, and now the answer appears to be sometimes."); Mantle, supra note 413, at § I-2.

429. See supra note 151 and accompanying text for a description of the three Supreme Court cases decided before the CONTU Final Report was issued. Two of these-Benson and Flookare discussed infra notes 430-36 and accompanying text. A fourth case, Diamond v. Dielur, 450 U.S. 175 (I981), discussed infra notes $437-40$ and accompanying text, was decided after the CONTU Final Report was issued, as were all of the Court of Customs and Patent Appeals decisions cited and discussed infra notes $441-49,447-49$ and accompanying text. The Freeman decision by the Court of Customs and Patent Appeals, cited and discussed infra notes $441-43$ and accompanying text, was decided several months before the CONTU Final Report was released. The Report makes no inention of the Freeman case. Because there is often several months delay in the publication of opimions, the Commission unay have been unaware of it. 
The pre-CONTU state of understanding about the availability of patent protection for programs did not give reason for much optimism. In Gottschalk v. Benson, ${ }^{430}$ the Supreme Court reviewed a claim for a process patent on a computer program for conversion of numbers from one form of bimary code to another. While it had been possible to perform this function previously, the existing procedure was very complicated and time-consuming whereas the method described in the patent application was simple and considerably faster. Despite the fact that this was an important and cominercially valuable innovation, the Supreme Court denied patentability. Benson seenied, to the Court, to be claiming a patent on a mathematical formula, and that the law did not permit him to do:

It is conceded that one may not patent an idea. But in practical effect that would be the result if the formula for converting BCD [Binary Coded Decimal] numerals to pure binary numerals were patented in this case. The mathematical formula involved here has no substantial practical application except in connection witl a digital computer, which means that if the judgment below is affirmed, the patent would wholly pre-empt the mathematical formula and in practical effect would be a patent on the algorithm itself. 431

This decision has been criticized by commentators, ${ }^{432}$ but remaims a viable and important precedent which calls into question the availability of patent protection for programs themselves. Benson is the only Supreme Court case directly to rule on the patentability of coniputer programs per se as processes.

Several years after Benson, the Supreme Court again had occasion to rule on the patentability of coniputer progranis. In Parker $v$. Flook, ${ }^{433}$ the computer program at issue was not the whole of the process claimed to be patentable, but only the novel element of that process. For many years, those who operated catalytic converters had been measuring operating conditions such as temperature, pressure, and flow rates im order to calculate "alarm limits" which indicated whether conditions within the converter were abnormal or dangerous and required corrective actions. ${ }^{434}$ Usmg a basic algorithın already in existence, Flook had written a computer program which allowed the alarm himits to be contmuously updated. ${ }^{435}$ The Supreme Court thought Flook to be seeking, as Benson had, a patent on a mathenuati-

430. 409 U.S. 63 (1972).

431. Id. at 71-72.

432. See, e.g., Note, Protection of Computer Programs: Resurrection of the Standard, 50 NOTRE DAME LAW. 333 (1974).

433. 437 U.S. 584 (1978).

434. Id. at 585 .

435. Id. at $585-86$. 
cal formula, and hence rejected his claim as unpatentable. ${ }^{436}$ Although the Supreme Court did not say that processes involving computer programs were not patentable, its holding was discouraging for those who thought such protection desirable.

Only three years later, in Diamond $v$. Diehr, ${ }^{437}$ the Supreine Court was agam faced with a process patent claim involving a computer program. Diehr had sought a patent on a process for curing rubber, the novel element of which was a computer program that permitted continuous monitoring and updating of information about conditions within the rubber inold and that signaled when the mold should be opened. The process produced perfectly cured rubber. Prior to Diehr's process, rubber was often improperly cured. ${ }^{438}$ This invention thus solved a long-standing industry problem. Because the process, "when considered as a whole, [was] performing a function [of the sort] which the patent laws were designed to protect (e.g., transforming or reducing an article to a different state or thing),"439 the Supreme Court held that Diehr had recited a patentable claim. This case was hailed as a significant victory for the patentability of programs. 440 And yet it did not hold that a program in itself could be patentable as a process.

The Supreme Court has not been the only court to struggle with fashioning a standard for reviewing the patentability of coinputer prograins. The Court of Customs and Patent Appeals has reviewed inany such claims in recent years and has inade numerous efforts to refine the standard. In re Freeman ${ }^{441}$ involved a typesetting process which utilized a computer prograin. ${ }^{442}$ The court said it would use a two-step test to determine whether the process claimed in a patent application and involving a coinputer program could be considered to be subject matter covered by the patent statute. The first step was to determime whether the claim directly or indirectly recited an "algorithun" in the sense used im Benson. The second step was to assess whether granting a patent on the claim in its entirety would wholly preempt use of that algorithm. Only if the claim atteinpted to preeinpt entirely the right to use the algorithm would there be a statutory subject matter problem

436. Id at $594-95$.

437. 450 U.S. 175 (1981).

438. Id. at 192.

439. Id.

440. See, e.g., Nimtz, Diamond v. Diehr: A Turning Point, 8 RutGers CoMpUTER \& TECH. L.J. 267 (1981).

441. 573 F.2d 1237 (C.C.P.A. 1978).

442. Id. at 1238. In other words, the computer program made the computer into a typesetting machine. 
with patentability. ${ }^{443}$ This seemed to give patent applicants two ways of avoiding the Benson/Flook abyss-one by carefully drafting the patent application so that it did not appear to recite an algorithm, and the other by claiming the right to exclusive use of the algorithm only as to specific applications or specific machimes.

The Freeman test was modified somewhat by In re Walter. ${ }^{444} \mathrm{Wal}$ ter involved a program for seismic testing and surveymg, which the court held to be nonpatentable subject matter. The court elaborated on the second step of the Freeman test:

If it appears that the mathematical aIgorithm is implemented in a specific manner to define structural relationships between the physical elements of the claim (in apparatus claims) or to refine or limit claim steps (im process claims), . . . the claim passes muster under $\S 101$. If, however, the mathematical algorithm is merely presented and solved by the claimed invention, as was the case in Benson and Flook, and is not applied in any manner to physical elements or process steps, no amount of post-solution activity will render the claim statutory; nor is it saved by a preamble merely reciting the field of use of the mathematical algorithm. 445

Walter seems to be trying to make a distinction between mathematical algorithms and nonmathematical algorithms, a distinction any computer scientist would find absurd. ${ }^{446}$ Despite this, the court lias contimued to use or refine this test im making patentability decisions. ${ }^{447}$ Its attempts at refinement lave made no discernible progress toward clarity.

If one tried to discern a pattern im the morass of these cases, one would be led to conclude that no matter low inventive a program may be, unless it is part of an apparatus or process of a sort traditionally regarded as patentable, and unless it brings about a new way of pliysi-

443. Id. at 1245 .

444. 618 F.2d 758 (C.C.P.A. 1980).

445. Id. at 767.

446. See, e.g., Gemignani, Legal Protection of Software: A Survey, in ADVANCES IN COMPUTERS 19-20 (M. Yovits ed. 1983) (discussing the artificiality of a distinction between "inathematical" and "nonmathematical" algorithms); see also Davidson, supra note 380, at 353-54 (criticizing C.C.P.A.'s "undue fixation" on algorithms).

447. See, e.g., In re Pardo, 684 F.2d 912 (C.C.P.A. 1982) (reversing rejection of patent claims relating to a compiler program; discusses Freeman and Walter and concepts of "nonmathematical algorithms"); In re Abele, 684 F.2d 902 (C.C.P.A. 1982) (holding that certam claims in patent application involving computer program used im computerized axial tomograghy (CAT scan) machine whicli related to reduction of X-ray exposure and improvement of images were patentable subject matter, while other claims imvolving mathematical algorithms were not patentable subject matter, discussing Freeman and Walter and reinterpreting Walter in light of Diehr); In re Taner, 681 F.2d 787, 790 (C.C.P.A. 1982) (holding that a method of seismic exploration involving a computer prograin was patentable subject matter; distinguishing Walter by focusing on the "process of converting one plysical thing into another physical thing"). 
cally transforming something from one state to another, it is unlikely that the program will be found patentable. In re Meyer ${ }^{448}$ is an example of a program denied patentability because it represented only a mental process and was not applied to plysical elements or process steps. ${ }^{449}$ In other words, it lacked the transformation characteristic. Meyer had developed an "expert system" program to aid neurologists in making diagnoses of patients based on case history and test data fed into the program. This program paralleled the thought processes of the physician but was designed to be niore consistent, more thorough, more reliable, and faster than a plysician might be. A great many computer programs which are exceedingly complicated and expensive to develop and refine and which are very valuable to users are precisely of the sort illustrated in Meyer. These programs parallel liuman thought processes-but without the ignorance, errors, omissions, and distortions to which the liuman mind is so often subject. Yet patent law will not protect thein.

\section{Perceived Limitations of Trade Secret Law.}

Because secrecy is so important to software authors and vendors, one might think trade secret law would offer the best form of protection for computer programs. It is nideed the favored form of protection at the moment. 450

The most serious limitation on the effectiveness of trade secret law as a form of protection for computer programs is that once the program has been sold without a restrictive agreement requiring maimtenance of secrecy, anyone who-without engagnig in imdustrial espionage-can obtam and replicate it can do so without incurring liability for stealing a trade secret. ${ }^{451}$ With programs on tapes, disks, and chips, replication is not only possible but easy, and one need not understand the programs to copy them. 452 One way to attempt to protect computer programs as trade secrets is to enter into restrictive licensing agreements instead of selling them outright. 453 The restrictions in such a licensing

448. 688 F.2d 789 (C.C.P.A. 1982).

449. Id. at 796.

450. See, e.g., Mantle, supra note 413, at § I-3 ("Despite Diehr, at present (and for the foreseeable future) protection of software under trade secret principles in most instances will be more significant (and more predictable) than copyright or patent protection."); see also L. GASAWAY \& M. MURPHY, supra note 428, at 69; Goldberg, supra note 413, at 68; Stern, supra note 164, at 438.

451. See, e.g., Videotronics, Inc. v. Bend Elecs., Inc., 564 F. Supp. 1471 (D. Nev. 1983) (rejecting trade secret claim for videogame program because plaintiff made no effort to restrict access to the encoded program).

452. Id. at 1476.

453. See, e.g., Gilburne, A Practical Approach to the Coordinated Use of Copyright and Trade Secret Protection for Licensing or Selling Software, COMPUTER LAW INSTITUTE, supra note 95, at 
agreement would be aimed at establishing procedures for keeping the secrets secret and out of the hands of persons other than the licensee. The law will usually protect those who make reasonable efforts to keep their secrets secure. ${ }^{454}$ But what a reasonable effort to maimtain secrecy is depends on the circumstances. ${ }^{455}$ Given that "hacking" to gam improper access to computer systems is a common sport among young computer enthusiasts, ${ }^{456}$ the standards for maintaining trade secrecy as to computer programs may be higher than for other types of works.

There are several other problems with restrictive agreements as a way to maintain trade secret protection. One is that some potential purchasers inay be unwilling to enter into these restrictive agreements. 457 Another is that it is not always possible for the licensee to do the kind of monitoring of access and of user conduct that may be necessary to preserve the secrecy. ${ }^{458}$ Such monitoring is expensive and the user may not be willing to bear those costs. Another problem is that if the secret is uncovered and transferred to one who takes without knowledge of the trade secret rights of the licensor, there may be no effective remedy for the wronged party against the good faith user. ${ }^{459}$ Still another is that restrictive agreements do not guard against the major threat to trade secrecy-eniployee departure from the firm trying to maintain the secret. 460

Trade secret law is also problematic as a forn of protection because of its common law roots. ${ }^{461}$ The content of trade secret law varies somewhat froin state to state. ${ }^{462}$ The lack of uniformity in trade secret law may be particularly troublesome to those who market their computer programs nationally. The possibility of some preemption of

§ IV; Gilburne \& Johnston, Trade Secret Protection for Software Generally and In the Mass Market, 3 COMPUTER LAW J. 211, 224-27 (1982).

454. I R. Milgrim, Milgrim on Trade Secrets $\$ 2.04$ (1982).

455. Id. at $\S \S 2.04,2.07$.

456. See, e.g., Trial and Error by Intruders Led to Entry Into Computers, N. Y. Times, Aug. 23, 1983, at A1, col. S; Computer Tampering Reported by Hospital, N. Y. Times, Aug. 20, 1983, at A33, col. 4 .

457. See, e.g., Gilburne, supra note 453, at § IV-7.

458. See, e.g., Gilburne \& Johnston, supra note 453, at 221-27 (recommending elaborate security procedures for maintaining program secrecy); see generally 1 MILGRIM ON TRADE SECRETS, supra note 454 , at $\$ \S 2.04,2.05$ (concerning loss of secrecy).

459. See I Milgrim ON TRADE SECRETS, supra note 454, at \& 5.04[2]; Stern, supra note 164, at 438.

460. See, e.g., GCA Corp. v. Chance, 217 U.S.P.Q. 718 (N.D. Cal. 1982); BPI Systems, Inc. v. Leith, 532 F. Supp. 208 (W.D. Tex. 1981). See also Gilburne \& Johnston, supra note 453, at 222$24,238-54$.

461. See, e.g., CONTU Final REPORT, supra note 1, at 17-18, discussed supra note 152.

462. See, e.g., Stern, supra note 164, at 438. Lack of uniformity in trade secret law was one of the reasons CONTU rejected trade secret law in favor of copyright for computer prograns. See CONTU FINAL REPORT, supra note 1, at 17. 
state trade secret law by copyright law as to computer programs is another real danger. ${ }^{463}$ So trade secrecy law too has serious limitations as a form of legal protection.

VI. The Alternatives: Convert Copyright to General MisapPropriation LaW, MOdify COPYRIGHT to MAKE EXCEPTIONS FOR MACHINE CODE, OR DEVELOP A NEW Form OF PROTECTION For This Special Kind of Intellectual Property

Several alternatives are available to resolve the dilemma presented by machine-readable computer programs that, as the previous discussion has shown, do not fit well into the existing intellectual property structure. One is to accept the conversion of copyright to a general misappropriation law. This approach would involve abandoning both disclosure as a goal of copyright law and the rule that the "utility" of a work bars protection under copyright law. It would also mean that copyright would take over many of the functions of trade secret and patent law. One would, of course, have to be prepared to live with the consequences of this decision, not only with respect to computer programs, but for other types of copyrightable subject matter as well. Television sets and airplane wings would be copyrightable too if the utility objection were abandoned. The constitutionality of such a development is questionable, but Congress may decide it is willing to test the issue.

A less drastic but more complicated option would be to do some "patch-up" work on thc copyright law to make exceptions to the traditional copyright rulcs which would be applicable only to programs in inachine-readable form. To lieal the wound to copyright primciples, one might require that the source code be filed with the Copyright Office for works published in machine-readable form. One might also revise the copyright statute to restrict the category of utilitarian works that are copyrightable to machine-readable forms of computer programs. Although requiring disclosure of source code might remove one constitutional problem, the constitutional problem with protectimg utilitarian works would remain even with this more limited surgery upon copyright law.

A preferable alternative is to devise a separate category of protection for computer programs in machine-readable form, one more appropriate for the specific type of intellectual property that programs are and more responsive to the specific necds of the industry that produces

463. See generally Luccarelli, supra note 230 . 
it. ${ }^{464}$ This latter alternative would have the advantage of allowing the principles of copyright law to be left intact, and would avoid the constitutional problems presented by the other two alternatives. A new forin of protection could draw on copyright concepts to the extent they were helpful, and discard those that were not. Some concepts could also be taken from patent law. 465 Soine concepts found in neither law but appropriate to the subject matter could be allowed to develop.

While this might seein to be a radical solution, one inust recognize that both patent and copyright law have been legal responses to historical change and to new phases in technological developments. $466 \mathrm{Be}-$ cause many beheve that current developments in the computer and other commumications technology fields are of at least the same level of historical importance as the Industrial Revolution, ${ }^{467}$ the creation of a new form of protection appropriate to this new phase of technology is worth considering seriously. That the existing forms of law do not satisfy the industry's needs reinforces the value of such a consideration.

Unfortunately, it may be necessary to have another commission empaneled to propose the new form of legal protection for inachine-

464. See, e.g., Goldberg, supra note 413 , at 70 ("Computer software surely is different from other forms of intellectual and industrial property, and a new legal mechanism nuust be devised to protect it. The most desirable form of protection is one of relatively short duration which limits the need for extensive disclosure, which defines the scope of coverage with precision, and which can be enforced effectively."); see also Apple Coniputer, lnc. v. Formula Int'l, Inc., 562 F. Supp. 775 (C.D. Cal. 1983) (acknowledging that copyright law nay not be the most appropriate form of protection for computer programs, but indicating that it is up to Congress to develop a new law); Galbi, Proposal for New Legislation to Protect Computer Programming, 17 BuLl. CopYRIGHT Soc'y 260 (1970), Stern, supra note 413, at 222 ("Software is clearly different enough and important enough to justify its own system of legislative protection.").

465. See, e.g., Goldberg, supra note 413, at 69 ("Many of the new suggestions and proposals being inade for software protection, except for those which urge inerely a strengthening of the status quo, . . . seein to be based on the realization that a level of protection less than patents and greater than statutory copyright is needed."). The Goldberg article also contains a discussion of an IBM software protection proposal that borrowed soine concepts from patent and some from copyright law and added soine new features. Id. at 70 .

466. As noted supra note 27 and accoinpanying text, the first copyright law was adopted to deal with the "piracy" that the invention of the printing press inade possible. See also supra note 28 and accompanying text.

Indeed, Congress has just recently recognized a new form of legal protection for computer chip designs precisely because neither patent nor copyright alone was satisfactory for this type of subject inatter. See N.Y. Times, Oct. 10, 1984, at AI, col. 4. The new protection is a hybrid of patent and copyright law, see supra note 350, and represents "a new form of intellectual property," the first such new form created by federal statute since the Trademark Act of 1881, N.Y. Times, Oct. 10, 1984, at A41, col. 1. (quoting Richard H. Stern, an attorney representing the semiconductor industry); see also 130 CoNG. REC. H11,610-11 (daily ed. Oct. 9, I984) (statement of Rep. Kastenuneier on the Semiconductor Chip Protection Act of 1984).

467. See supra note 29 and accompanying text. 
readable forms of programs. ${ }^{468}$ Congress will be understandably reluctant to set up another commission to study this matter. After all, it has already done this once. However, the last commission that studied the issue simply did not have the expertise necessary to make the best decision on the matter. 469 There should be computer scientists, professional programmers, software industry and hardware industry representatives, and large and small users of computer systems on the commission studying and recommending the kind of legal protection computer programs im machine-readable form ought to have. 470

Among the reasons to have computer scientists on such a commission is that they will understand not only present but also past and probable future developments in this rapidly changing field, and they are likely to be the most concerned about the need to ensure adequate disclosure of program ideas in order to advance the science. They will also tend to take a longer range view of the issues. The software imdustry, the primary target of piracy, has, of course, the most immediate stake in the controversy. Its representatives also have strong views about what the law ought to protect. Their views on the need to minimize disclosure to give adequate protection to programs should be heard. Hardware manufacturers have an interest in legal protection for machine-readable versions of programs for two reasons: First, they often produce machine-readable programs, namely, microcode and operating systems, for their machines; and second, they have some interest in minimizing restrictions on software so that their machines can more readily be used for a wide range of purposes. Users of programs, whether of highly complex or more simple systems, may have their own concerns about disclosure of program details and about the length and scope of legal protection for programs, and those concerns have not thus far been attended to.

This author firmly believes that it would be best for a commission of computer program experts to draft a new form of intellectual property law for machine-readable programs, and makes the following sug-

468. The last commission limited its consideration of forms of protection to those already in existence. This is understandable in view of the apparent congressional directive to deterunine if copyright was appropriate as a form of protection for programs.

469. See supra notes $137-39$ and accounpanying text.

470. See, for example, Stern, supra note 413, at 216: "Lawyers and other amateurs have in the past pontificated on the nature of software and on such issues as whether its 'essential character' (and therefore the appropriate system of protection) is more like that of the subject matter of patents or copyrights. This is an mteresting academic and metaphysical inquiry. Perhaps the time has come for those in the software industry to see whether they can make more sense of the matter." Obviously, it would also be helpful to have someone with expertise in intellectual property law to give guidance to those whose expertise lies in computer-related fields. 
gestions for such a group's consideration. ${ }^{471}$ First, there should be a disclosure requirement imposed on one who receives federal protection for a machine-readable version of a program. Disclosure as a quid pro quo for the grantimg of a federal monopoly right is an essential part of the federal imtellectual property scheme. ${ }^{472}$ A strong argument can be made that the Constitution requires disclosure as a prerequisite to the granting of federal protection, for it is only by disclosure of creative ideas that science and the useful arts will be fostered and progress in thein assured. 473

What form such a disclosure requirement ought to take $\mathrm{e}^{474}$ and how soon any disclosure document ought to be made available to the public ${ }^{475}$ are issues likely to generate considerable controversy. The software imdustry can be expected to argue strongly for minimal disclosure and for as much delay as possible im making the disclosure documents available to the public. Scientists and users can be expected to argue for nnaximum disclosure and no delay. On this issue, some reasonable compromise should be possible.

Second, there should also be a requirement that prompt application be made in order for machine-readable programs to be ehgible for federal protection. Patent law requires an imventor who wants a patent to file a patent application within one year of commencement of

471. Although the author does not think it necessary to dwell on the need for a uniform national system of protection or on the desirability of a registration process similar to those developed for patent and copyright, she regards these as basic elements of a new form of protection. The author agrees with CONTU that the need for uniformity in the law makes a federal system of protection the most desirable option. See CONTU FINAL REPORT, supra note 1, at 19.

472. See supra notes $173-78$ and accompanying text.

473. See supra notes $190-200$ and accompanying text. One might argue that much of the progress made thus far in the programming field is attributable to the fact that there has been relatively widespread dissemmation of program ideas, especially im academic circles. Even CONTU recognized the undesirability of secrecy for computer programs from the standpoint of furthering scientific endeavors. See CONTU FINAL REPORT, supra note 1, at 17-18; see also supra notes 27377 and accompanying text.

474. One might require a programmer to file with a federal office one or more copies of the full text of the source code, or of a fiow chart of the program, or of some other commonly prepared document such as an imternal specification document. One might also adopt a kind of patent-based model which could simply require a description of the algorithm of the program and its implementation in sufficient detail to allow one skilled in the art to develop a comparable program. See supra notes 241-44 and accompanying text; see also Goldberg, supra note 413, at 70 (discussing 1BM's software protection proposal, which would lave required disclosure of a description of the concept of a program at the tine of registration; the proposal would have required complete disclosure of the program upon expiration of the term of protection). As in patent law, failure to nake adequate disclosure should be considered a fraud on the federal registration office and a basis for imvalidation of the right. See supra notes 246-47 and accompanying text.

475. Even if the Constitution were interpreted to require that disclosure be made, it would not necessarily require immediate disclosure. See supra note 474. 
nonexperimental use of the invention. 476 One who fails to file promptly is barred froin obtaining patent protection, although trade secret protection reinains available to the extent the subject inatter can be kept secret. 477 The same policy considerations that make this rule appropriate for patent law make it appropriate for whatever intellectual property law is devised to cover inachine-readable computer programs.

Third, in view of the utilitarian character of machine-readable programs, the length of legal protection available for thein should be considerably less than the seventy-five years froin the date of publication that now obtains for corporate copyright owners. 478 Patent protection, the form of federal legal protection ordinarily applied to utilitarian works, is less than one-quarter this length. The duration of the patent law inonopoly has long been deemed a reward to inventors sufficient to stimulate invention. 479 Moreover, outside the United States, many proposals for software protection that are now under serious consideration would grant much shorter periods of legal protection for computer programs than the present American copyright duration. ${ }^{480}$ Although the author does not favor the proposal that would extend copyright protection to computer chip designs, she would note that even this proposal would limit such copyright protection to ten years. ${ }^{481}$ That the commercial life of most programs seems to be quite

476. See supra notes $251-54$ and accompanying text.

477. Id.; see also supra notes $255-56$ and accoinpanying text.

478. See supra notes $325-26$ and accompanying text. See also supra note 201 and accompanying text regarding the argument that seventy-five years is too long a period of protection, given the present lack of disclosure of the programs.

479. The patent term has been seventeen years in duration since 1861. See CHISUM ON PATENTS, supra note 328, at $\$ 16.04[1]$. It is worth probing further the reasons why it nnay be desirable to have a shorter term of legal protection than seventy-five years. Granting a monopoly right to the creator of a utihtarian work (such as a computer prograin) ineans that society is allowing the creator to restrict production of that useful itein and to keep prices at higher levels than would obtain if free competition were allowed as to that subject inatter. The law in free enterprise cconounies generally frowns on such restrictions. Because of the need for some rewards to those who create in order to stimulate thein to be creative, society has been willing to compromise and grant exclusive rights to creators-but only for limited periods. Granting exclusive rights for all time or for a very long time not only is not needed to stimulate the creative work in the first place, but may in fact be counterproductive.

480. A proposal seriously being considered in Japan would limit software protection to fifteen years. See N. Y. Times, Jan. 18, 1984, at 33, cols. 5 \& 6. Even the World Intellectual Property Organization Model Provisions for software would limit the period of protection to 20 years. See Abel, World-Wide Protection of Computer Soffware: An Analysis of the WIPO Draft Proposal, 2 N.Y.L.S. J. INT'L \& CoMP. L. 278, 307-08, 315 (1981).

481. See supra notes 325, 350-53 and accoinpanying text; see also H.R. 2985, 98th Cong., 1st Sess. (1983) (would amend the copyright law to grant ten years of copyright protection to ornamental designs for useful articles); 26 PAT. TrademarK \& CopYright J. (BNA) No. 638 (July 21, 1983) $246,246$. 
short ${ }^{482}$ is yet another reason for making the length of protection considerably shorter than that which copyright now provides.

Fourth, serious consideration ought to be given to granting some legal protection to innovative ideas embodied im programs that cannot now be protected by patent because they are mathematical formulas or other sets of "mental steps," 483 assuming that such protection would be constitutional. ${ }^{484}$ The imdustry's dissatisfaction with existing legal forms of protection is at least partly due to a perceived "gap" in protection. ${ }^{485}$ Grantimg some, perhaps more limited, period-say, three or five years - of protection for innovative algorithms or other ideas einbodied in programs might make the imdustry more satisfied with the law, and thus perhaps more willing to disclose its ideas in writings describing the programs. ${ }^{486}$

Fifth, careful thought must be given to how clear lines demarcating the new form of intellectual property law from both patent and copyright can be drawn. It will be easier to do this vis-à-vis copyright law than vis-à-vis patent law. With respect to copyright, one could say that copyright protection should be available for audio, visual, or audiovisual displays produced by computer programs, and for data bases stored on computers-regardless of whether the data base is a compilation of facts, a novel, or a set of images or sounds-to the extent that these works would qualify for copyright protection if made available in more traditional "hard-copy" form. Copyright protection should also be available for the "output" of a computer, to the extent the output would otherwise qualify as an original work of authorship and is nonutilitarian in the copyright sense. Copyright protection should also be available for source code, flow charts, and other written depictions of program ideas, although subject to the rule of Baker $v$. Selden that the art the source code describes is not protected by the copyright. ${ }^{487}$ Copyright protection should not, however, be available for machimereadable forms of programs, and it should not be considered an in-

482. See, e.g., Seneker \& Pearl, supra note 25, at 94; Note, International Copyright Law Applied to Computer Programs in the United States and France, 14 LoY. U. CHI. L.J. 105, 126 (1982) (marketable life span of most programs is ten to fifteen years).

483. See supra notes $429-49$ and accompanying text.

484. See, e.g., Gottschalk v. Benson, 409 U.S. 63, 67 (1972) (discussion of cases that question whether it is constitutionally permissible to grant intellectual property rights in abstract intellectual concepts).

485. See supra notes 419 \& 428 and accompanying text.

486. One author has suggested that the West German "petty patent" concept might be adapted to deal with some of the deficiencies of American patent and copyright law. See Note, Petty Patents in the Federal Republic of Germany: A Solution to the Problem of Computer Software Protection?, 8 Sw. L. J. 888 (1976). Perhaps this concept could be used to protect algorithms. 487. See supra notes $182-85$ and accompanying text. 
fringement of copyright to convert source to machine-readable code any more than it is an infringement of a copyright in blueprints to make a house described by the blueprints. Instead, there should be a separate forin of legal proteetion for machine-readable forins of programs. Such a law might consider conversion of copyrighted source code to a machine-executable form to be an infringement of the new legal right. Upon expiration of federal protection for the machinereadable forms of programs, it should be permissible for anyone to convert even a copyrighted source code into an executable form. ${ }^{488} \mathrm{~A}$ copyright in the written text of the source code could continue to protect against unauthorized reproduction of the source code in written text form even after the expiration of the machine-readable program right.

With respect to patent law, one might say that to the extent a programmer thinks he has developed a computer program which can be successfully claimed to be part of a patentable process, and would prefer to obtain a patent for the process rather than to seek protection for the program under the new legal scheme, he should be able to choose either form of legal protection. ${ }^{489}$ The same subject matter, however, should not be covered by more than one intellectual property right. One problem with separating patent law and a new legal form of protection for computer programs derives from the potential interchangeability of program and machine. ${ }^{490}$ It is always possible to build a completely hardwired machine to do whatever task a program for a universal machine can do. It may also be difficult to demarcate the patent realm from that of a new legal scheme if the latter provides protection for innovative but nonpatentable ideas. Although these problems may be difficult, they do not seem inherently unresolvable.

Sixth, the new commission should design a system of protection capable of adapting to foreseeable teclmological changes. In 1978, CONTU stated, "In the event that future technology permits programs

488. This would be similar to the Copyright Office rule of not accepting for copyright registration any documentation that las been submitted to the Patent Office as part of a patent application as to which a patent has issued. See 37 C.F.R. § 202.10(b) (1984).

489. It also ought to be possible for a programmer to opt for trade secrecy law as an alternative to patent law. See supra notes $255-56$ and accompanying text.

490. See supra notes 38-39 and accompanying text. At the very least, one would have to decide whether it would infringe the new property right for someone to build a hardwired machine to do that which the protected program did. It would be necessary to decide also whetlicr a program implementing a function (in conjunction with a coinputer) would infringe a patent on a machine that performs this function without a progran. Under the doctrine of equivalents, the manner of implementation of the idea may be sufficiently different so as not to infringe a patent on the machine. See 1 Chisum on PatenTs, supra note 328, at $\$ 18.04$; but see Davidson, supra note 380 , at $354-55$. 
to be stated orally for direct imput to a computer through auditory sensing devices . . . difficult questions will arise."491 CONTU did not say what those questions were, let alone how they should be resolved. But now that this technology is withm reach,492 a commission recommending a law for protection of programs should attempt to draft a law that can incorporate this as well as other foreseeable developments.

Despite agreement with copyright defendants' arguments concerning the conceptual problems of applying copyright principles to machine-readable forms of computer programs, the author does not champion the cause of software pirates. Until such time as a new form of protection can be enacted, courts should contimue to protect machine-readable computer prograins from piracy by application of such common law tort doctrimes as misappropriation, unfair competition, or trade secret law. ${ }^{493}$ Congress might also pass an interim measure establishing a federal cause of action for computer program misappropriation until a new intellectual property regime can be drawn up and adopted.

We should not be "locked" into thinking of copyright, patent, trade secret, and common law misappropriation as the only possible forms of legal protection for programs. Our short history of attempting to fit computer prograins into the established categories has proven unsatisfactory. A more satisfactory solution can be devised and can be made to work.

491. CONTU FINAL REPORT, supra note 1, at 22.

492. See, e.g., Feigenbaum, supra note 32 , at 119,129 . It may also soon be possible to program a machine, such as a robot, not through the use of words, but through a physical demonstration of the task to be performed. For example, a human hand might take a robot's hand through a series of steps necessary to tighten a bolt and thereby "program" it. See generally G. DODD \& L. Rossol, COMPUTER VISION \& SENSOR BASED ROBOTS (1979). There is also the possibility of storimg programs in some media other than silicon chips, e.g., magnetic bubble memories. See Boraiko, supra note 32, at 444.

493. See CONTU FinAl RePort, supra note 1, at 19. 